DEPARTMENT OF THE INTERIOR

FrankLIN K. LANE, Secretary

United States Geological SuRvey

GeORGE OTIS SMith, Director

Water-Supply Paper 428

\title{
ARTESIAN WATERS IN THE VICINITY OF THE BLACK HILLS, SOUTH DAKOTA
}

BY

N. H. DARTON

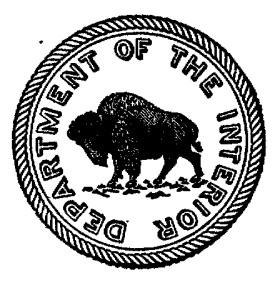

WASHINGTON

GOVERNMENT PRINTING OFFIOH

1918 



\section{CONTENTS.}

Introduction

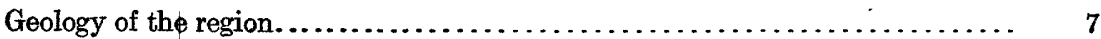

General structure and stratigraphy........................... 7

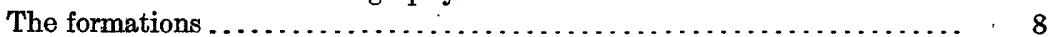

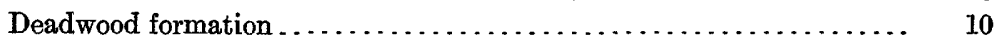

Whitewood limestone. . . . . . . . . . . . . . . . . . . . . . . . . . 11

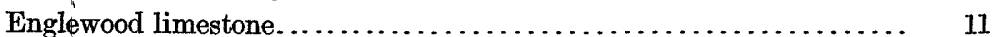

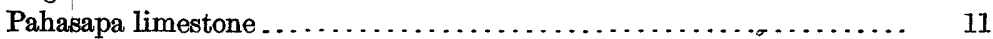

Minnelusa sandstone $\ldots \ldots \ldots \ldots \ldots \ldots \ldots \ldots \ldots \ldots \ldots \ldots \ldots \ldots, 12$

Opeche formation..................................... 13

Minnekahta limestone.................................... 13

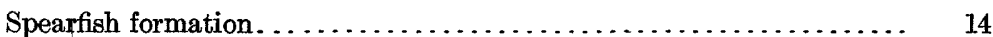

Sundance formation. . . . . . . . . . . . . . . . .

Unkpapa sandstone $\ldots \ldots \ldots \ldots \ldots \ldots \ldots \ldots \ldots \ldots \ldots \ldots \ldots, \quad 16$

Morrison shale.......................................... 16

Lakota sandstone........................................ 17

Minnewaste limestone................................... 17

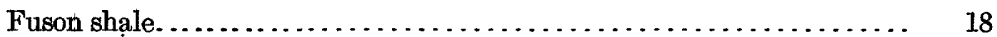

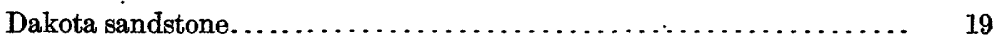

Graneros shale.............................................. 19

Greenhorn limestone................................... $\quad 20$

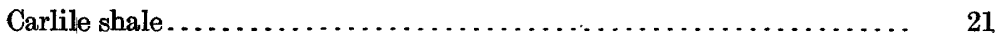

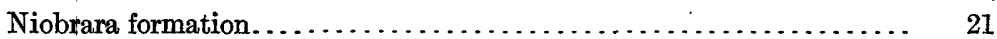

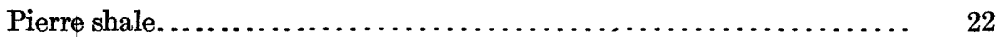

White River group...................................... 23

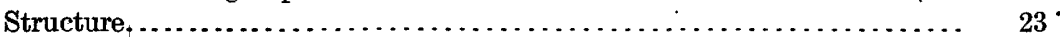

General features....................................... 23

Limestone Ridge........................................ 24

Anticline and syncline of Whitewood region................... 24

Red Valley in Spearfish region............................. 24

Bear Butte ............................................ 25

Hogback ridge and Red Valley south of Sturgis.'.............. 25

Pass Greek region ........................................ 25

Plains east of the Black Hills............................ 26

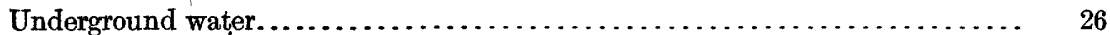

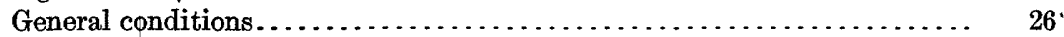

Depth to artesian water...................................... 28

Water-bearing sandstones................................... 29

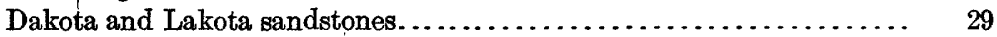

Formations between the Lakota and Minnelusa sandstones......... 32

Minnelusa andstone .................................... 33

Pahasapa and underlying limestones. ...................... 34

Deadwood formation ...................................... 34 
Borings and artesian prospects

Belle Fourche region........................................ 35

General features....................................... 35

Belle Fourche and vicinity ............................. 36

Belle Fourche project................................. $\quad 38$

Hay Creek valley...................................... 39

Chambers ranch........................................... 39

Orman............................................ 40

Snoma.............................................. 41

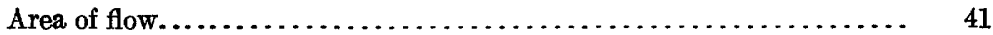

St. Onge and Whitewood region.............................. 41

Vale and Newell region.................................... 42

Sturgis and Bear Butte region.............................. 43

List of wells........................................ 43

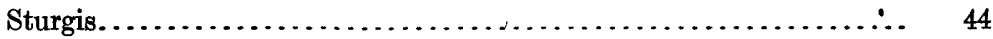

Fort Meade......................................... 47

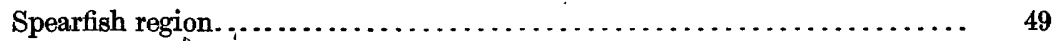

Rapid City region and eastward............................. 50

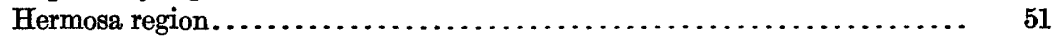

Fairburn region............................................ 52

Buffalo Gap and Smithwick region.......................... 52

Hot Springs and Minnekahta region.......................... 53

Edgemont region...................................... 55

Edgemont............................................ 55

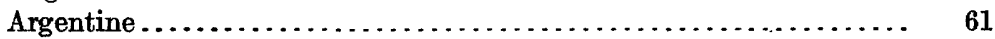

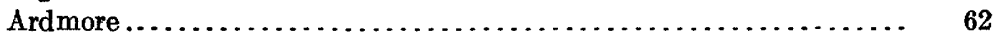

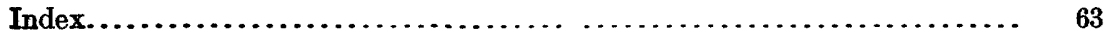

\section{ILLUSTRATIONS.}

Plate I. Map showing artesian-water conditions in South Dakota in the vicinity of the Black Hills....................... In pocket.

II. $A$, Upper sandstone of Deadwood formation in northern part of Deadwood, S. Dak.; $B$, Upper beds of Minnelusa sandstone, Bear Butte Canyon, west of Sturgis, S. Dak.

III. Upper sandstone of Deadwood formation in canyon of Box Elder Creek, S. Dak.

IV. Typical cliff of Minnekahta limestone capping red shale of Opeche formation.

V. Basal sandstone of Sundance formation: $A$, Exposure 6 miles north of Minnekahta, S. Dak.; $B$, Exposure 7 miles south of Hot Springs, S. Dak.

VI. Unkpapa sandstone in Odel Canyon, near Hot Springs, S. Dak.....

VII. Dakota and Lakota sandstones in canyon of Fall River, S. Dak....

VIII. East slope of hogback ridge south of Buffalo Gap, S. Dak ........

IX. Greenhorn limestone on Graneros shale south of Edgemont, S. Dak..

$X$. Sections showing relations of water-bearing sandstones in Black Hills region. 
Puate XI. Tepee buttes due to limestone lens in Pierre shale: $A$, Group of tepee buttes; $B$, Limestone core such as causes tepee buttes......

XII. $A$, Sink hole in Minnekahta limestone; $B$, Spring at Cascade Springs, S. Dak...................................

XIII. Characteristic fossils that serve as guides in well boring in the plains: $A$, Ostrea congesta of Niobrara formation; $B$, Inoceramus labiatus of Greenhorn limestone............................

Frgure 1. Columnar sections of rocks in the Black Hills and vicinity, showing thickness of beds, relation of water-bearing sandstones, and

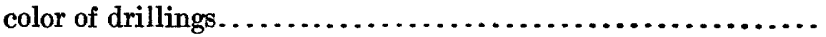

2. Section across South Dakota from the Black Hills to Missouri River, showing the general relations of water-bearing rocks....

3. Apparatus for illustrating the declivity of head of liquid flowing from a reservoir.

Page.

4. Profile from the Black Hills to Sioux City, Iowa, showing the gradient in the head of artesian water of the Dakota and Lakota sandstones from intake to outflow.

5. Outline map of South Dakota showing hydraulic gradient by contour lines of head...................................

6. Section of boring on Chambers ranch, 9 miles west of Belle Fourche, S. Dak

7. Section of boring at Enskert ranch, 3 miles northeast of Sturgis, S. Dak

8. Section of boring at Fort Meade, S. Dak., east of Sturgis, S. Dak. .

9. Section of deep boring at Minnekahta, S. Dak..................

10. Section of nonflowing well at Edgemont, S. Dak...............

11. Section of boring at railroad $Y$ three-fourths of a mile north of Edgemont, S. Dak. 



\title{
ARTESIAN WATERS IN THE VICINITY OF THE BLACK HILLS, SOUTH DAKOTA.
}

\author{
. \\ By N. H. Darton.

\section{INTRODUCTION.}

The foothills and plains adjoining the Black Hills in western South Dakota are semiarid and have been greatly retarded in development by the scarcity of water. Surface waters are meager in volume and at most places are considerably mineralized. Springs are rare, and as much of the area is underlain by clay or shale, the water from most shallow wells is unsatisfactory in quantity and quality. Several streams rising in or beyond the Black Hills cross the plains, but their flow and quality are variable. Fortunately the area is underlain by sandstones which receive water at their outcrops in the Black Hills and will yield it when tapped by wells, thus adding greatly to the resources of the region. To make the best use of these water-bearing beds a knowledge of the general geology of the region is necessary.

\section{GEOLOGY OF THE REGION.1}

\section{GENERAL STRUCTURE AND STRATIGRAPHY.}

The Black Hills uplift is an irregular dome or arch 125 miles long and 60 miles. wide, whose longer dimension lies nearly northwest and southeast. It has brought above the general level of the Great

${ }^{1}$ For a detailed account of the geology of the Black Hills, see Darton, N. H., Geology and underground water resources of the central Great Plains: U. S. Geol. Survey Prof. Paper 32, 1905 ; Darton, N. H., Preliminary description of the geology and water resources of the southern half of the Black Hills and adjoining regions in South Dakota and Wyoming: U. S. Geol. Survey Twenty-first Ann. Rept., pt. 4, pp. 489-599, 1901; Jaggar T. A., jr., The laccolithsi of the Black Hills: U. S. Geol. Survey Twenty-first Ann. Rept., pt. 3, pp. 163-303, 1901 ; Darton, N. H., U. S. Geol. Survey Geol. Atlas, Oelrichs folio (No. 85), 1902; Darton, N. H., idem, Newcastle folio (No. 107), 1904; Darton, N. H., and Smith, W. S. T., idem, Edgemont folio (No. 108), 1904 ; Darton, N. H., idem, Sundance folio (No. 127), 1905 ; Darton, N. H., and O'Harra, C. C., idem, Aladdin folio (No. 128), 1905 ; Darton, N. H., and O'Harra, C. C., idem, Devils Tower folio (No. 150), 1907 ; Darton, N. H., and O'Harra, C. C., idem, Belle Fourche folio (No. 164) 1909 ; Darton, N. H., Geology and underground waters of South Dakota: U. S. Geol. Survey Water-Supply Paper 227, 1909. 
Plains a mass of pre-Cambrian crystalline rocks, about which is upturned a nearly complete sequence of sedimentary formations that range in age from late Cambrian to late Cretaceous and that dip away from the central nucleus. It is also partly encircled by extensive overlaps of the Tertiary deposits, which constitute the surface of much of the adjoining plains.

The region affords great opportunity for the study of stratigraphic relations and variations. Many of the rocks are hard, and they are extensively exhibited in the walls of canyons and gorges cut by streams that flow from the central hills. The structure along the sides of the uplift is that of a monocline dipping toward the plains. The oldest sedimentary rocks constitute an escarpment facing the crystalline-rock area, and each stratum passes beneath a younger in regular succession outward toward the margin of the uplift. (See Pl. X; p. 26.) The sedimentary members consist of thick sheets of sandstone, limestone, and shale, all of which (except the overlapping Tertiary deposits, which extend across the edges of the older formations) are essentially conformable. The stratigraphy is in many respects similar to that in the Rocky Mountains of Colorado and of Wyoming, but it possesses numerous distinctive local features. The Silurian and Devonian and parts of the Cambrian, Ordovician, Carboniferous, Triassic, Jurassic, and Tertiary are absent. The following formations are exposed: 
Generalized geologic section in the Black Hills region in South Dakota.

\begin{tabular}{|c|c|c|c|c|}
\hline \multicolumn{2}{|c|}{ Age. } & Formation. & Character. & Ordinary \\
\hline Tertiary .. & Oligocene.. & $\begin{array}{c}\text { White River group: } \\
\text { Brule clay.... } \\
\text { Chadron for- } \\
\text { mation. }\end{array}$ & $\begin{array}{l}\text { Light-eolored clay, fuller's earth, } \\
\text { and sand. } \\
\text { Sand, clay, sandstone, conglom- } \\
\text { erate, and limestone. }\end{array}$ & $\begin{array}{r}\text { Feet. } \\
200 \\
100\end{array}$ \\
\hline \multirow[t]{2}{*}{ Cretaceous.......... } & UpperCretaceous. & $\left\{\begin{array}{l}\text { Pierre shale...... } \\
\text { Niobrara forma- } \\
\text { tion. } \\
\text { Carlile shale........ } \\
\text { Greenhorn lime- } \\
\text { stone. } \\
\text { Graneros shale.... } \\
\text { Dakota sandstone. }\end{array}\right.$ & $\begin{array}{l}\text { Dark-gray shale................. } \\
\text { Chalk and calcareous shale...... } \\
\text { Gray shales with thin sandstones, } \\
\text { limestones, and coneretions. } \\
\text { Impure slabby limestone........ } \\
\text { Dark shale with some lenses of } \\
\text { massive sandstone in its lower } \\
\text { part. } \\
\text { Massive buff sandstone........... }\end{array}$ & $\begin{array}{r}1,200 \\
175-225 \\
500-600 \\
65 \\
900-1,150 \\
20-200\end{array}$ \\
\hline & Lower Cretaceous. & $\left\{\begin{array}{l}\text { Fuson shale........ } \\
\text { Minnewaste lime- } \\
\text { stone. }\end{array}\right.$ & $\begin{array}{l}\text { Massive shales, white to purple, } \\
\text { and very fine grained sand- } \\
\text { stone. } \\
\text { Gray limestone................. } \\
\text { Massive buff sandstone, with } \\
\text { some intercalated shale. }\end{array}$ & $\begin{array}{r}30-150 \\
0-30 \\
100-300\end{array}$ \\
\hline \multicolumn{2}{|c|}{ Cretaceous (?) $\ldots \ldots \ldots \ldots \ldots \ldots \ldots \ldots$} & Morrison shale.... & $\begin{array}{l}\text { Massive shale, gray, greenish, } \\
\text { and maroorr. }\end{array}$ & $0-150$ \\
\hline \multicolumn{2}{|l|}{ Upper Jurassic. . } & $\left\{\begin{array}{l}\text { Unkpapa } \\
\text { stone. } \\
\text { Sundance } \\
\text { tion. }\end{array}\right.$ & $\begin{array}{l}\text { Massive fine sandstone, white, } \\
\text { purple, red, and buff. } \\
\text { Dark-gray shales and buff sand- } \\
\text { stones. }\end{array}$ & $\begin{array}{r}0-225 \\
100-300\end{array}$ \\
\hline \multicolumn{2}{|l|}{ Triassic (?). } & $\begin{array}{l}\text { Spearfish forma- } \\
\text { tion. }\end{array}$ & $\begin{array}{l}\text { Red sandy shale with gypsum } \\
\text { beds. }\end{array}$ & $550-695$ \\
\hline \multirow{3}{*}{ Carboniferous...... } & Permian (?). & $\left\{\begin{array}{l}\text { Minnekahta lime- } \\
\text { stone. } \\
\text { Opeche forma- } \\
\text { tion. }\end{array}\right.$ & $\begin{array}{l}\text { Thin-bedded gray limestone..... } \\
\text { Red slabby sandstoneand sandy } \\
\text { shale. }\end{array}$ & $\begin{array}{r}30-50 \\
75-130\end{array}$ \\
\hline & Pennsylvanian.. & 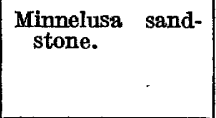 & $\begin{array}{l}\text { Sandstones, locally buff and red, } \\
\text { in greater part calcareous; } \\
\text { some thin limestoneincluded; } \\
\text { red shale at base. }\end{array}$ & $400-500$ \\
\hline & Mississippian. & $\begin{cases}\text { Pahasapa } & \text { lime- } \\
\text { stone. } & \text { Englewood lime- } \\
\text { stone. } & \end{cases}$ & $\begin{array}{l}\text { Massive gray limestone... ... } \\
\text { Pink slabby limestone. . ... }\end{array}$ & $\begin{array}{r}300-600 \\
30-50\end{array}$ \\
\hline \multicolumn{2}{|c|}{ Ordovician...$\ldots \ldots \ldots \ldots \ldots \ldots \ldots$} & $\begin{array}{l}\text { Whitewood lime- } \\
\text { stone. }\end{array}$ & Massive buff limestone........... & $0-80$ \\
\hline \multicolumn{2}{|c|}{ 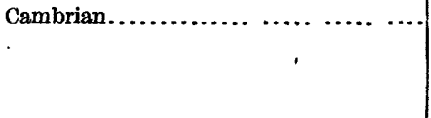 } & $\begin{array}{l}\text { Deadwood forma- } \\
\text { tion. }\end{array}$ & $\begin{array}{l}\text { Red-brown sandstoneandquartz- } \\
\text { ite, locally conglomeratic, } \\
\text { partly massive; much greenish- } \\
\text { gray shale andlimestone brec- } \\
\text { cia in middlein northern hills. }\end{array}$ & $50-450$ \\
\hline
\end{tabular}


THE FORMATIONS.

DEADWOOD FORMATION.

The Deadwood sandstone encircles the Black Hills uplift and underlies a wide adjoining region but has been removed from the central area by erosion. The strata lie unconformably on the upturned edges of the pre-Cambrian schists, grits, and granites, on a surface that is relatively smooth except for shallow local channels. The formation is thick in the northern hills, attaining more than 400 feet in the Deadwood region, but it thins gradually to. the south and especially to the southeast. For a short distance in the region west of Fairburn it consists of only 4 feet of coarse sandstone, but near Pringle and Wind Cave it is 50 to 60 feet thick. On Lightning Creek, west of Hill City and Custer, near Otis, and on Spring and French creeks it averages 100 feet. On Rapid and Squaw creeks it averages about 200 feet; on Elk and Little Elk creeks 250 feet; and near Galena and in Spearfish Canyon 450 feet.

The materials are predominantly sandy and the color dark reddish . brown or dirty buff. The basal member is ordinarily a hard massive reddish-brown sandstone or quartzite that contains pebbly layers. To the north, where the formation thickens, this member is overlain by thinner-bedded softer sandstones, in some places interbedded with more or less shale. Portions of the basal Deadwood beds are conglomeratic, ranging from those with a sprinkling of quartz pebbles in the sandstone to a very coarse heavy conglomerate made up of large rounded masses of crystalline rocks and vein quartz in a redbrown matrix.

Outcrops of the Deadwood sandstone range from a few rods to several miles in width but are generally narrow. For many miles they lie in the slope below the high escarpments of the Pahasapa limestone, where in places, particularly on the west side of the uplift, they are deeply buried under talus from the cliffs above. On the east side, where the dip is steeper, the hard quartzitic basal member forms prominent knobs or long bare rocky slopes. The many canyons cutting back into the western escarpment and those crossing the ridges on the east side of the uplift afford excellent exposures.

In the region about Deadwood and in a large part of the northern hills the formation comprises 1 to 30 feet of basal conglomerate, overlain by. 30 feet of sandstone, in turn overlain by 200 to 300 feet of gray shales that carry layers of flaggy limestone, limestone conglomerate, and sandstone. Near the top is a very characteristic member of hard, massive sandstone 5 to 22 feet thick (see Pls. II and III), overlain by 20 to 45 feet of green shales. The limestone conglomerate layers consist of flat pebbles and flakes of limestone more or less thickly sprinkled with grains of glauconite. 


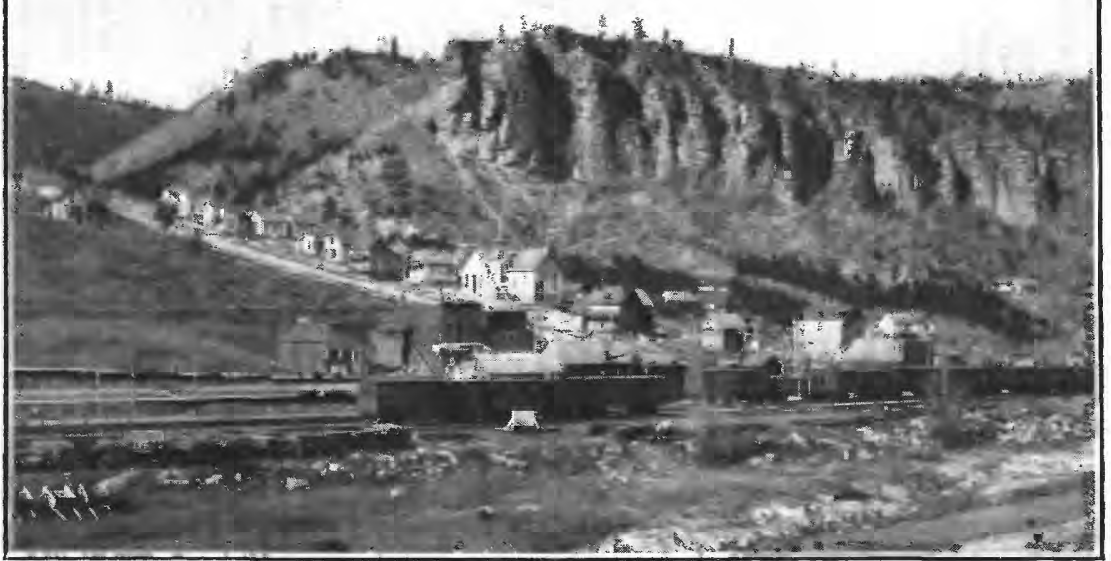

A. UPPER SANDSTONE OF DEADWOOD FORMATION IN NORTHERN PART OF DEADWOOD, S. DAK., LOOKING NORTHEAST.

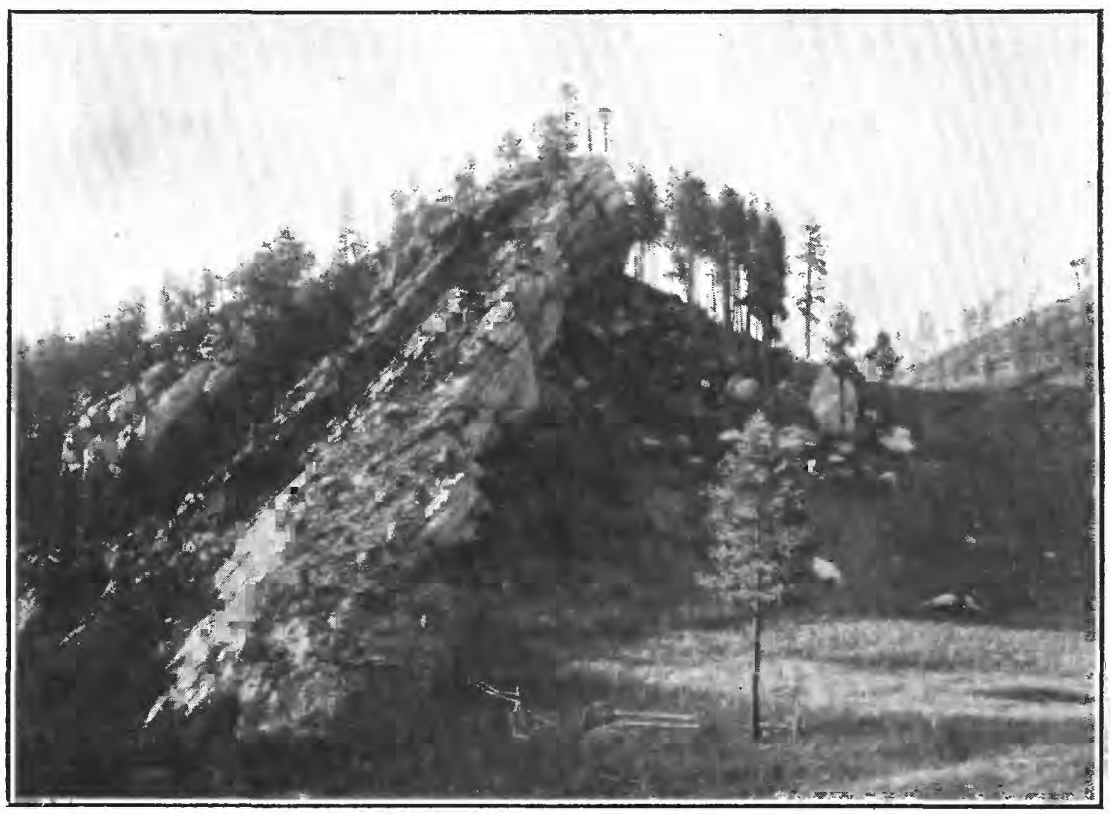

B. UPPER BED OF MINNELUSA SANDSTONE, BEAR BUTTE CANYON, WEST OF STURGIS, S. DAK., LOOKING NORTH. 


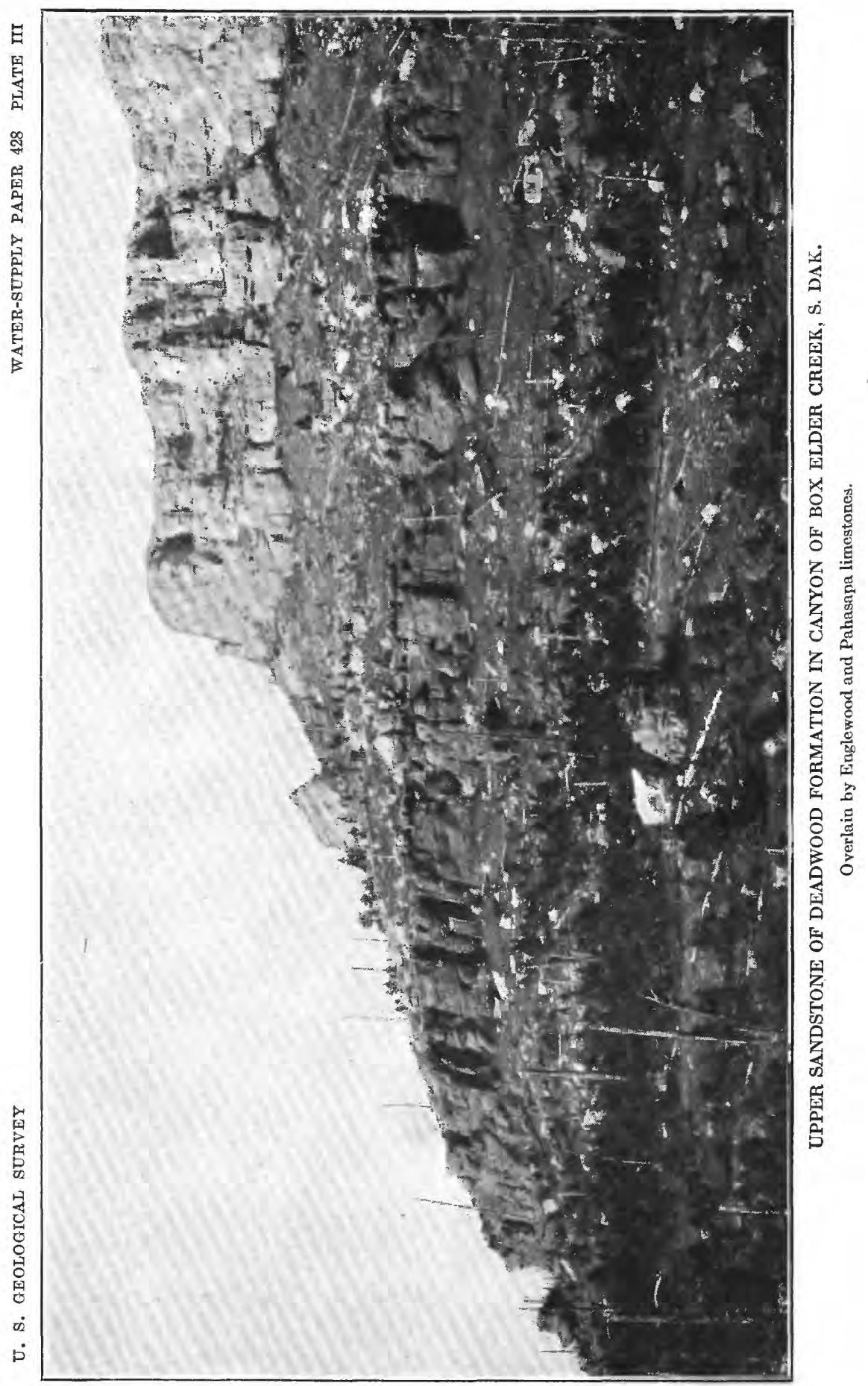


WHITEWOOD LIMESTONE.

The Whitewood limestone is conspicuous in the northern Black Hills, particularly in.Spearfish Canyon and about Deadwood, where it attains a thickness of 60 to 80 feet and crops out extensively in a number of canyons, a typical exposure appearing in Whitewood Canyon below Deadwood. It thins to the southeast and southwest and finally disappears west of Piedmont. The rock is a massive tough limestone of buff color with brownish spots or mottlings.

ENGLEWOOD LIMESTONE.

The Englewood limestone consists of 30 to 60 feet of thin-bedded pale pinkish-buff limestones, which appear to extend continuously around the Black Hills, outcropping in the lower slopes of the limestone escarpment and in canyons, everywhere immediately beneath the Pahasapa limestone. It merges rather abruptly into the overlying Pahasapa, here and there with a few feet of impure buff limestone intervening. Generally it is sharply separated from the Deadwood formation or the Whitewood limestone by an abrupt change in the nature of the materials. It is usually fossiliferous, containing numerous corals and shells of earlier Mississippian age.

\section{PAHASAPA LIMESTONE.}

The Pahasapa limestone is conspicuous in the Black Hills uplift, constituting; much of the high, wide plateau west of the central crystalline rocks and being characteristically exhibited in the great lines of cliffs in the escarpment surrounding that region. It is a thick, massive gray limestone, usually outcropping either in precipitous cliffs, with many picturesque irregularities of form or in wide, flat surfaces. The formation has no noteworthy divisions, but in many places its upper part is siliceous and flinty and more or less stained red by the overlying basal red shale of the Minnelusa.

The most extensive exposures of the Pahasapa limestone are in the wide, high plateau west of Custer. Here the formation begins in a line of high cliffs surmounting slopes of crystalline schists and of relatively thinner sheets of Englewood limestone and Deadwood sandstone. In Pennington County the plateau shows a width of 10 miles of continuous limestone outcrop, constituting the most elevated area in the Black Hills, except the small summit of Harney Peak. To the west the limestone passes beneath the Minnelusa sandstone, but it is exposed again in the arch of the steep anticline near the Wyoming-South Dakota line. East of the area of crystalline rocks the limestone forms many conspicuous knobs or lies on the eastern 
slopes of ridges formed by the quartzite of the Deadwood formation, but it does not attain the high altitude which it has farther west. To the east the steeper dip carries the formation below the surface within a short distance, but it constitutes the walls of many of the canyons from Beaver Creek northward, notably the deep canyon of Spearfish Creek. In it are some extensive caverns, including Wind Cave, Jewel Cave, Crystal Cave, and Onyx Cave.

The thickness of the Pahasapa limestone in the central and southern Black Hills ranges from about 550 feet at the northwest to 300 feet at the east and southeast. Along the southeast side of the hills it measures 300 feet, with slight local variations; it increases to 550 feet or more on Elk Creek and to 600 feet on Bear Butte Creek; and it ranges from 300 to 400 feet in the Deadwood region. In Spearfish Canyon it is 630 feet, at Crow Peak 550 feet, and in the plateau northwest of Custer and Hill City, 500 feet. Fossils indicating lower Mississippian age occur sparingly in the formation.

\section{MINNELUSA SANDSTONE.}

The Minnelusa sandstone extends around the Black Hills uplift in a broad zone of conspicuous exposures. The rocks are mainly thick masses of buff and reddish sandstones, mostly fine grained and massively bedded, which are striking features in the walls of many canyons. In their unweathered condition they contain considerable carbonate of lime. Thin sheets of limestone and of red and gray sandy shales occur in places. At the base is a red shale that contains thin beds of limestone. The formation is thickest on the west side of the uplift, where it attains 500 feet. It thins gradually to the south and east, being 405 feet thick south of Spearfish, 450 feet on Whitewood and Bear Butte creeks, 500 feet on Elk and Boxelder creeks, 400 feet on Rapid Creek, 460 feet on Spring Creek, and about 420 feet west of Hot Springs.

The Minnelusa sandstone does not give rise to very large topographic features but generally occupies extensive elevated slopes surmounted by low hills and ridges formed by its harder layers.

Breccias characterize its middle beds throughout the southern Black Hills. The brecciated material is usually somewhat more calcareous than the matrix, but it is all of local origin. In the region west of Hermosa and thence northward the Minnelusa consists of a thick coffee-colored sandstone (see Pl. II, $B$ ), underlain by a reddish-buff sandstone with some thin interbedded limestone layers, and this in turn by a basal member of gray sandstone, which lies on red shale that contains thin layers of limestone. 
A fow fossils found in the upper beds west of Hot Springs appear to indicate that the formation is of Pennsylvanian (upper Carboniferous) age.

\section{OPECHE FORMATION.}

The red beds of the Opeche formation, which lies between the Minnelusa sandstone and the Minnekahta limestone, crop out continuously around the Black Hills, mostly in the slopes below the escarpments of Minnekahta limestone, with an average thickness of somewhat less than 100 feet. The materials are soft red sandstone and sandy shale, mainly thin bedded and containing variable amounts of clay admixture. The top of the formation, for the first few feet below the Minnekahta limestone, consists of shale, which is invariably deep purple. The basal beds of the formation usually consist of red sandstone in beds 4 to 15 inches thick.

On Spring, Battle, and French creeks the formation averages about 100 feet in thickness, and in Beaver Canyon it attains its maximum thickness of 140 feet. On Cold Brook, 4 miles northwest of Hot Springs, where it is $\mathbf{1 1 5}$ feet thick, it consists of the customary purple clay at the top, 50 feet of red sandy clay next below, and 60 feet of red sandstone at the bottom, in beds 1 to 4 feet thick with redclay partings. Farther down Cold Brook, at a point $1 \frac{1}{2}$ miles from Hot Springs, a thickness of 135 feet is exhibited. On Rapid and Elk creeks it is 90 feet thick. Along the southwest side of the Black Hills the thickness averages from 70 to 90 feet, and on the northern slopes it is about 75 feet.

The age of the formation has not been definitely determined, for so far it has yielded no fossils. It has been assumed to be Permian.

\section{MINNEKAHTA LIMESTONE.}

The Minnekahta limestone, long known as the "Purple limestone," is prominent in the Black Hills region. Though thin, averaging less than 50 feet, it is hard and covers moderately extensive areas on the outer slopes of the Minnelusa sandstone outcrop zone. The prominence of the Minnekahta limestone outcrop is due largely to the deep erosion of the soft red shale of the overlying Spearfish formation, which has left the limestone bare on slopes up which the red shale originally extended. As the underlying Opeche formation is also soft, the limestone nearly everywhere presents an escarpment, and the many canyons which are cut through it have vertical limestone walls. (See Pl. IV.) Its thickness is 45 feet on Rapid Creek, 40 feet on Elk, Bear Butte, and Battle creeks, and 30 feet on Whitewood, Spring, and Spearfish creeks. 
The formation is uniform in character throughout, being a thinbedded light-colored limestone containing magnesia and more or less clay. Its thin bedding is characteristic, although the thin layers are so cemented together that the outcropping ledges present a massive appearance. On weathering, however, it breaks into slabs, most of which are 2 to 3 inches thick. In general it is slightly pinkish, with a tinge of purple, from which the term "Purple limestone" originated. The Minnekahta limestone contains some fossils which are regarded as of probable Permian age, though they may be Triassic.

\section{SPEARFISH FORMATION.}

The Spearfish formation is a conspicuous series of red beds with gypsum deposits that encircles the Black Hills, in most places giving rise to the wide Red Valley. This valley is treeless and for the most part consists of broad, bare red slopes and red buttes, with numerous outcrops of gypsum.

The formation consists of 550 to 695 feet of red sandy shale, with intercalated beds of gypsum in places 30 feet thick. The bright red of the shale and the snowy whiteness of the gypsum are striking features. Were it not for the beds of gypsum the formation would present no noticeable features of stratigraphy. The red shale contains different amounts of sand in different localities, and includes some soft, thin-bedded red sandstones. The gypsum occurs in beds, some of which extend continuously over wide areas. More or less gypsum of secondary deposition, in very small veins, is scattered through the formation.

The continuity of the outcrops of the red beds is considerably broken in the region west of Fairburn and Hermosa by overlaps of the White River deposits, which in some places completely fill the Red Valley. The width of the outcrop is 1 to 3 miles and attains a maximum in the region west of Buffalo Gap and in the broad belt extending from Minnekahta station nearly to the north end of Elk Mountain. Owing to the local steep dip of the formation, the outcrop is very narrow for 5 miles north from Cascade Springs.

The thickness of the Spearfish formation can in few places be determined with any degree of accuracy, owing to the softness of its materials and the numerous variations in its dip. In the deep well at Fort Meade the formation is 695 feet thick and in the Edgemont wells about 600 feet. Along the east side of the Black Hills it appears to be 550 to 600 feet thick, so far as can be estimated from very indefinite observations of dip. In this region the principal bed of gypsum occurs about 100 feet above the base of the formation. West of Hermosa this gypsum bed has a thickness of about 15 feet, but toward the sputh, in the region west of Fairburn, it thins out and 


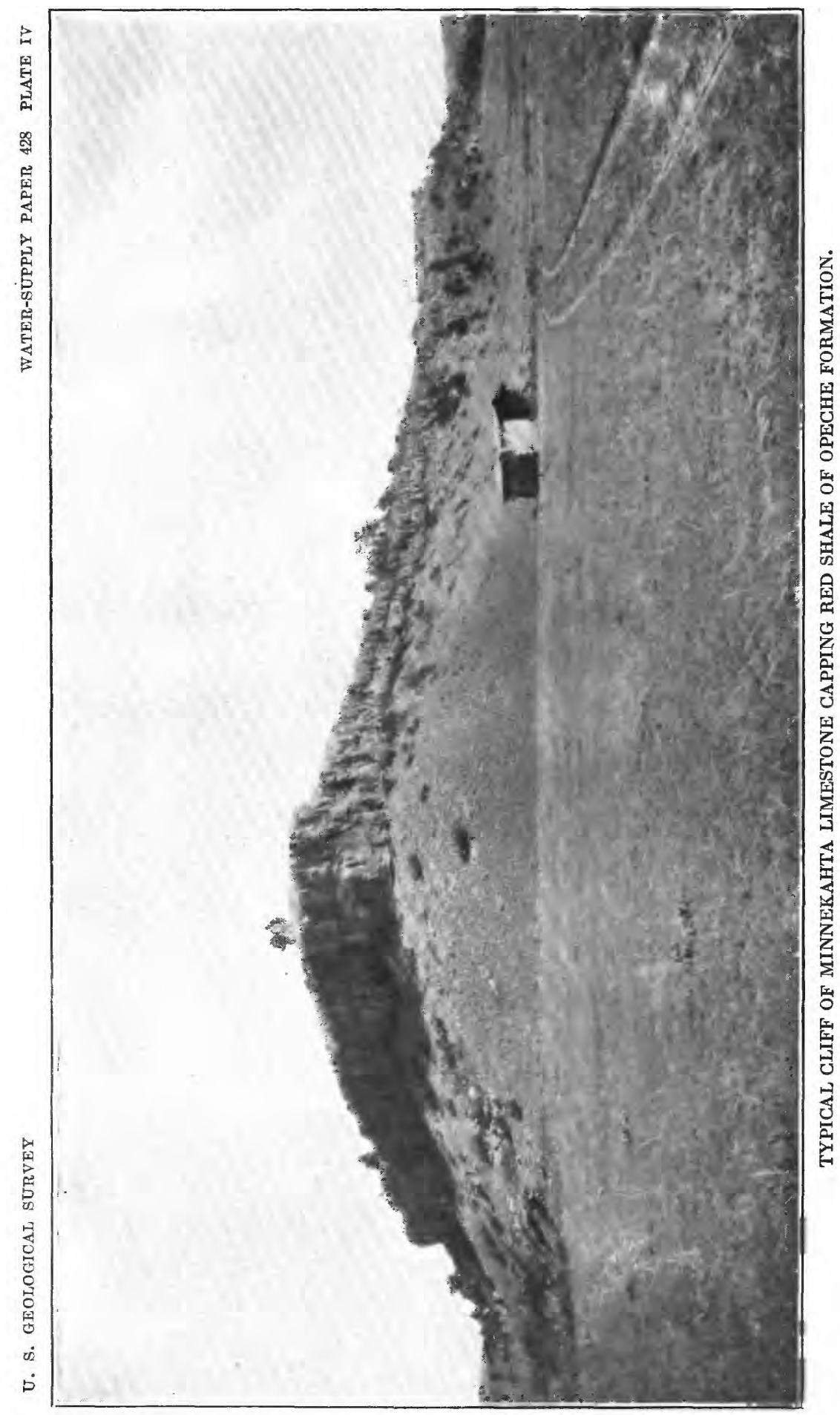




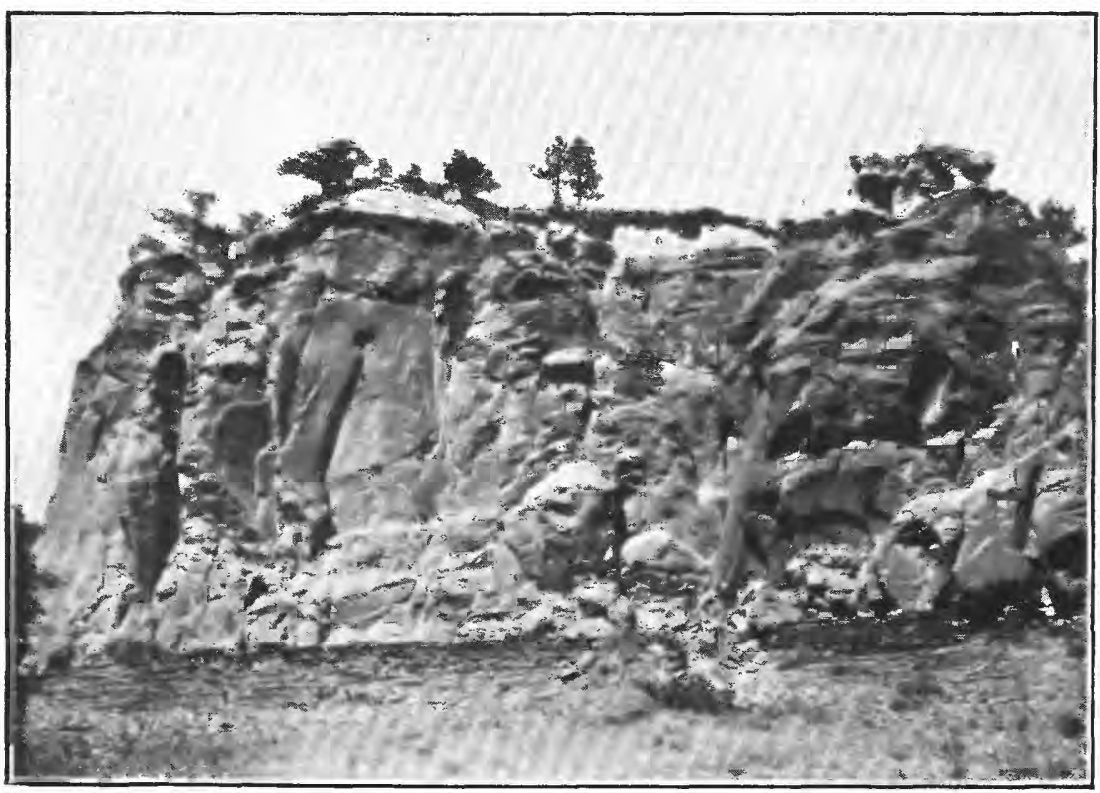

A. EXPOSURE 6 MILES NORTH OF MINNEKAHTA, S. DAK.

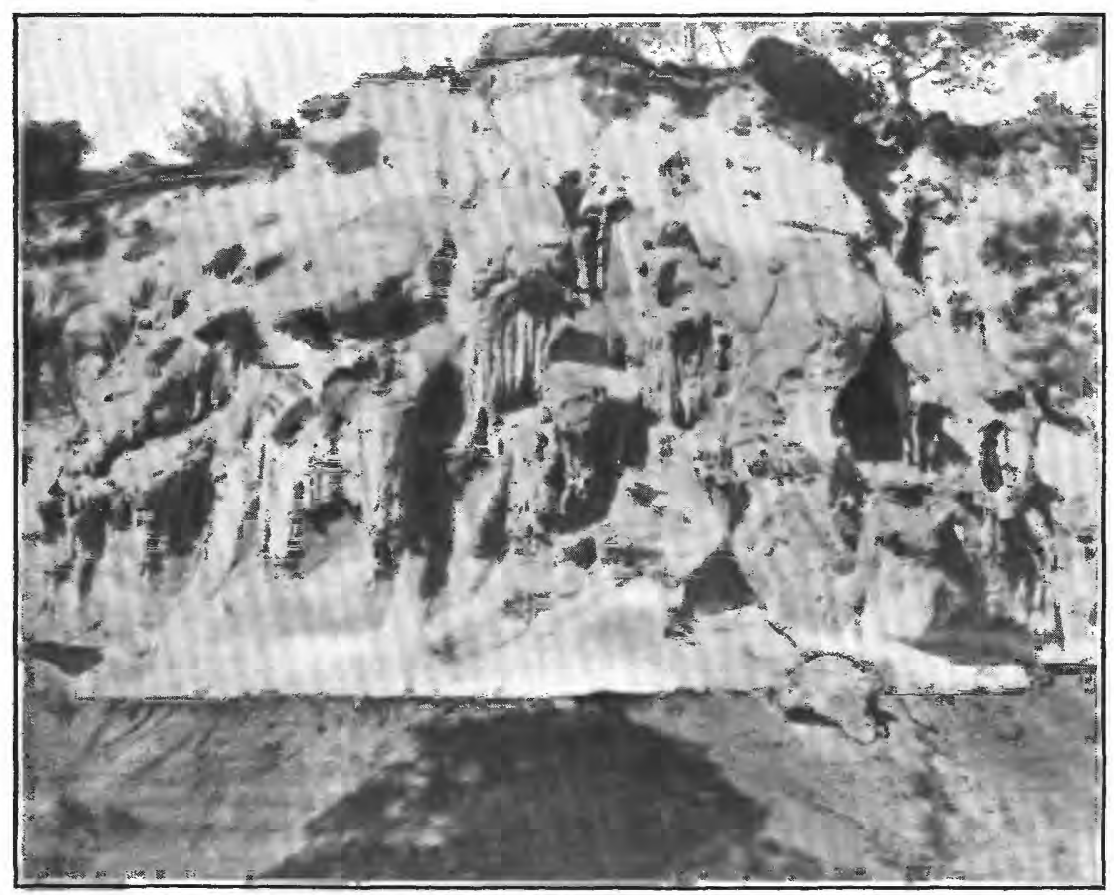

B. EXPOSURE 7 MILES SOUTH OF HOT SPRINGS, S. DAK.

BASAL SANDSTONE OF SUNDANCE FORMATION. 
may at some points be absent. Near Spearfish and Sturgis a thick bed of gypsum lies near the top of the formation and a thinner bed about 120 feet above the base. West of Buffalo Gap the gypsum deposits increase in thickness, and they attain a maximum at Hot Springs, where the principal beds have a thickness of $33 \frac{1}{2}$ feet, with a 10-foot parting of red shale between them. In the wide part of Red Valley, extending southward from Hot Springs to Sheps Canyon, gypsum beds are conspicuous, but they gradually diminish in thickness in that direction.

At Cascade Springs and thence northward on the west side of the anticline the dips are very'steep, and the outcrop of the Spearfish formiation becomes so narrow that the Red Valley is only a few rods in width from the springs northward nearly to, the railroad. Here a measurement was made of the beds from the steep slopes of the Minnekahta limestone to the basal sandstone bed of the Sundance formation, 420 feet in all, but doubtless the strata are considerably squeezed in a steep fold of this sort. At the base of the Spearfish formation in this section is 150 feet of red sandy shales, above which is a bed of gypsum in places 20 feet in thickness, overlain by 250 feet of red sandy shales, with a few thin layers of gypsum.

Throughout the Black Hills the formation is distinctly separated from the underlying Minnekahta limestone and the overlying shales or red sandstone of the Sundance formation. It has been regarded as probably Triassic in age, because it lies unconformably beneath marine Jurassic deposits and is underlain by the Minnekahta limestone of supposed Permian age, but as yet it has yielded no determinable fossils.

\section{SUNDANCE FORMATION.}

The outcrop of the Sundance formation extends continuously around the Black Hills uplift, mainly along the outer slope of the Red Valley, or the lower, inner slope of the hogback ridge. The formation comprises 225 to 300 feet of shales and sandstones, in a series that differs but little in sequence in different portions of the region. The succession includes 50 to 60 feet of lower dark shale, 30 feet of massive buff ripple-marked sandstone, 30 feet of reddish sandy shale, and at the top 100 to 200 feet of green shale that contains thin fossiliferous limestone layers. Some local variation occurs, especially in the massive red or buff basal sandstone, which in many places attains a thickness of 25 feet and lies on the somewhat irregular surface of the red shale of the Spearfish formation. (See Pl. V.) West of Fairburn the formation thins to less than 100 feet for a short distance. The abundant marine fossils are of later Jurassic age. 


\section{UNKPAPA SANDSTONE.}

The Unkpapa sandstone, the next overlying formation, is everywhere clearly separable both from the Sundance formation below and the Morrison shale or the Lakota sandstone above. It is a very massive fine-grained sandstone, which ranges in color from white to purple and buff. Its greatest development is in the hogback ridge east of Hot Springs. Its first outcrops to the south are observed about Cascade Springs, from which it extends continuously past Hot Springs, along the east side of the Black Hills. It is thickest in Sheps Canyon, southeast of Hot Springs, where 225 feet was measured. From Buffalo Gap to French Creek it ranges from 125 to 150 feet, except near Dry Creek, where it is only 90 feet. From Spring Creek nearly to Rapid City it is 40 to 60 feet. At Rapid City it is 125 feet and north of Rapid City 140 feet, but it thins north of Blackhawk and is 40 feet near Piedmont and Tilford. From Sturgis north it is very thin and inconspicuous.

The coloring of some of the exposures east of Hot Springs is very striking, the rocks being brilliant in pink, purple, and pure white. (See PI. VI.) Near Buffalo Gap, where the rock has been quarried to some extent for building stone, portions of it are beautifully banded in different colors, in part along the stratification planes but in places diagonal to them. In the quarry west of Buffalo Gap these banded beds exhibit most instructive minute faulting, affording fine illustrations of block-fault phenomena. Contacts with the overlying buff Lakota sandstone are exposed at many points and are marked by considerable erosional unconformity.

\section{MORRISON SHALE.}

The outcrop of the Morrison shale extends along the upper and inner slopes of the hogback ridge, but is absent in the southeastern part of the uplift, from the vicinity of Hermosa to a point southwest of Hot Springs. Elsewhere the formation is generally from 75 to 150 feet thick and lies between the Unkpapa sandstone, or Sundance formation, and the Lakota sandstone. The maximum thickness observed was 220 feet in slopes 2 miles north of Piedmont. It ranges from 75 to 100 feet between Sturgis and Spearfish. The formation is composed mainly of "joint clay" or massive shale, somewhat darker and more fissile to the east than to the north and west. The predominating color is a very. pale greenish gray, merging into chocolate and maroon. Thin beds of fine-grained white or light-gray sandstone and some thin local layers of impure limestone are included.' A few fresh-water shells were observed, and there is an almost general occurrence of dinosaur bones, which are classed as Jurassic bv some paleontologists and as early Cretaceous by others. 


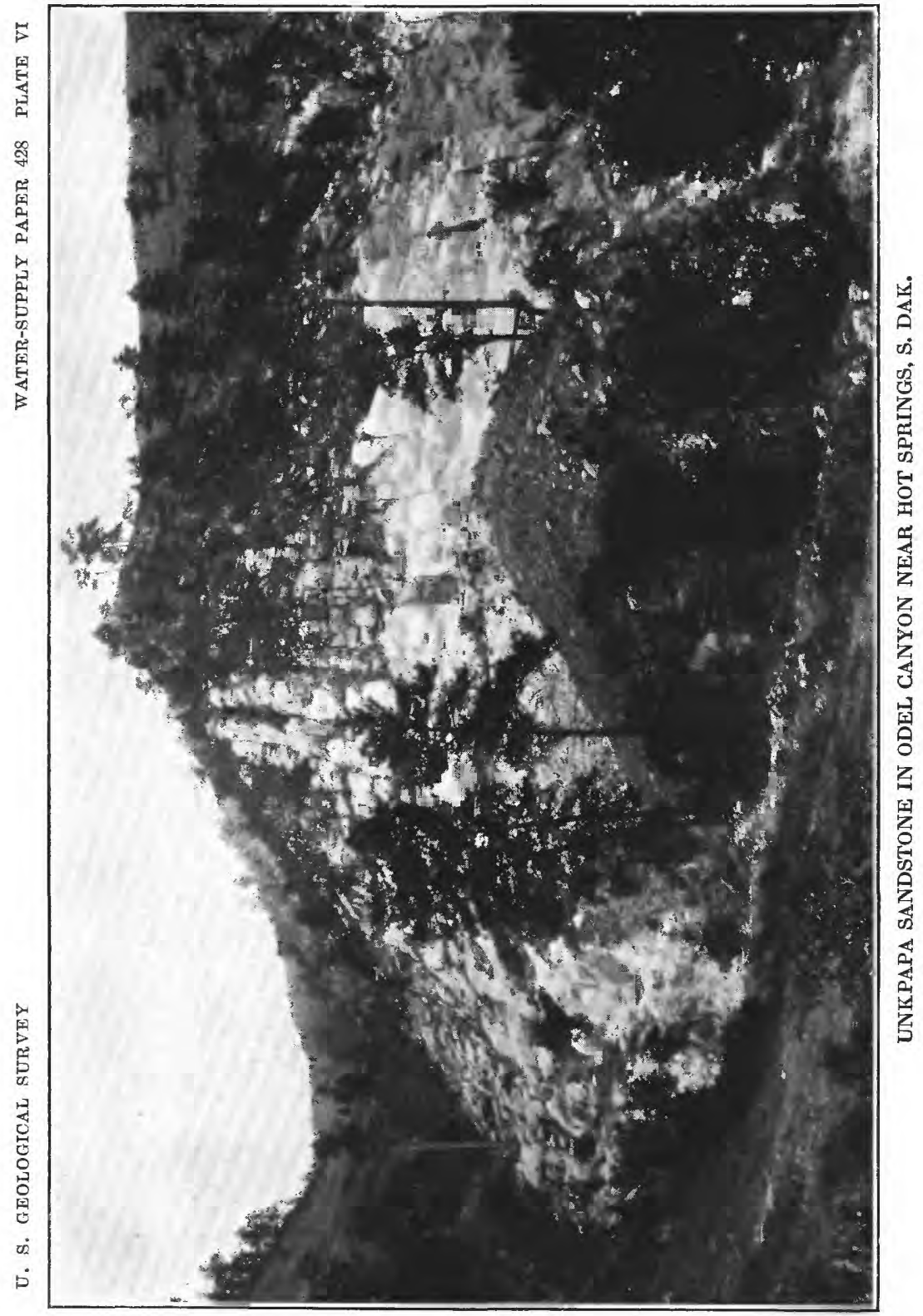




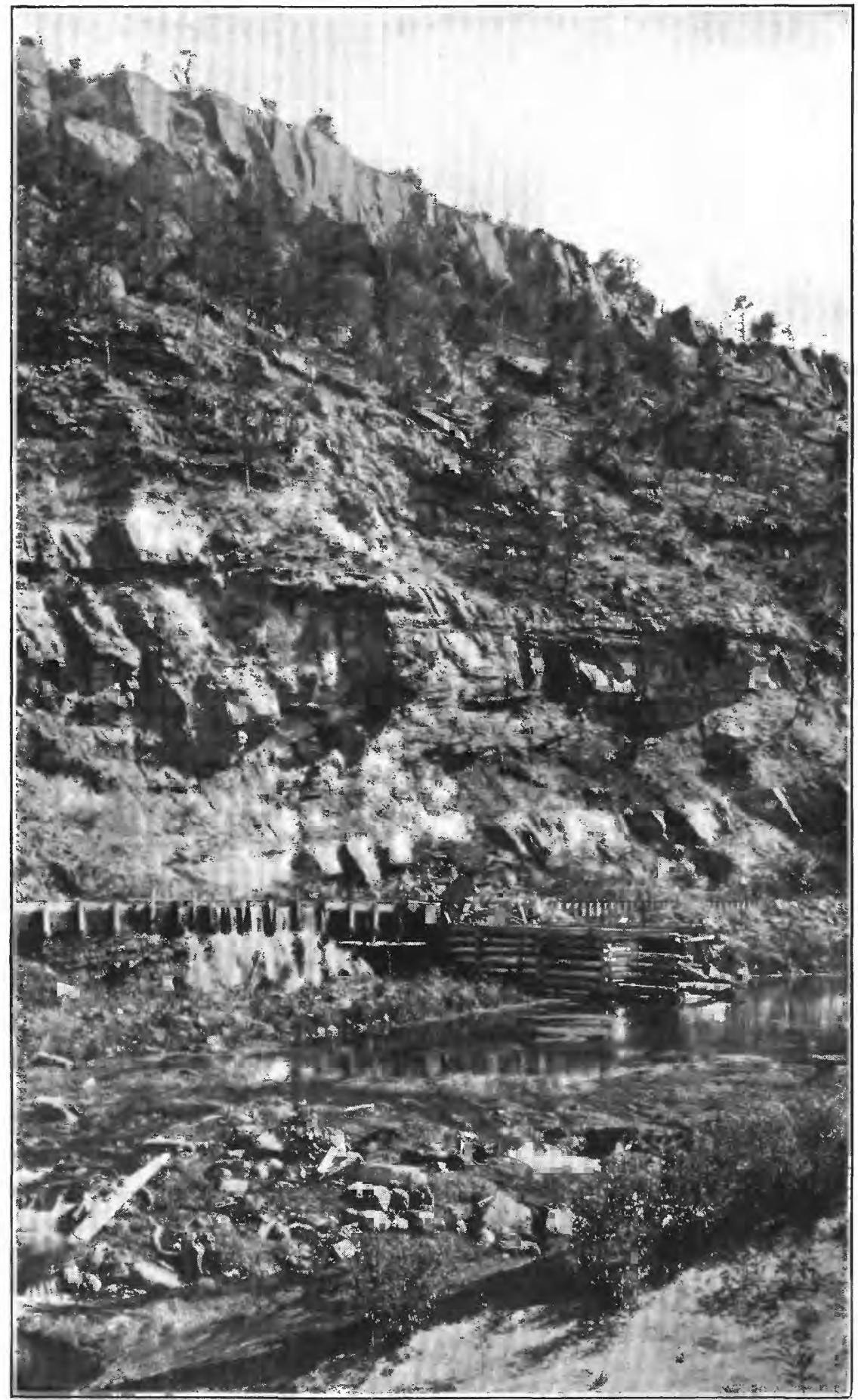




\section{LAKOTA SANDSTONE.}

The Lakota sandstone constitutes the crest and upper slopes of the hogback ridge that forms the outer encircling rim of the Black Hills. Its beds are hard, coarse grained, cross-bedded, and massive, with partings of shale of no great thickness. Local deposits of coal occur in its base about Cambria, on Hay Creek, and east of Edgemont. In the central and southern Black Hills the thickness is usually 200 to 300 feet, though it differs locally; to the north it averages about 100 feet. Its maximum is about 480 feet in Fuson Gap. On French, 'Dry, and Squaw creeks it is about 300 feet, and in Elk Mountain and on Pass Creek 200 feet. The Lakota lies on the Morrison shale, except in the region from Hermosa to a point beyond Hot Springs, where it overlaps unconformably on the Unkpapa sandstone.

The Lakota sandstone shows numerous local variations in the thickness of the beds and in the occurrence of intercalated shales. In the canyon of Fall River, where the formation is 225 to 250 feet thick, the sandstones are very massive and are separated by several beds of greenish-gray shale 15 to 20 feet thick. (See Pl. VII.) The uppermost member, a dull-yellow sandstone, is overlain by the Minnewaste limestone in the region east of Hot Springs. The lower beds are conglomeratic at most localities.

Except petrified wood, which is abundant, few fossils have been found in the Lakota sandstone. A few bones of a stegosaur were obtained near Buffalo Gap; and remains of isopods, Estheria, fish, and crocodile were found 3 miles north of Piedmont. Plants of Lower Cretaceous age occur east of Hot Springs and in the Hay Creek region, and pine needles are abundant in some of the coaly layers. Cycads are found in places, notably in the slopes southwest of Minnekahta and near Blackhawk.

MINNEWASTE LIMESTONE.

The Minnewaste limestone, a nearly pure light-gray limestone of uniform character throughout, overlies the Lakota sandstone from the vicinity of Cascade Springs northward to Buffalo Gap. For the greater part of its course it is only 25 feet thick, but it is conspicuous on the hogback ridges east of Hot Springs, extending far up some of the higher slopes. One of the most extensive exposures is on Cheyenne River 8 miles southeast of Hot Springs, where the water falls over a ledge of it about 20 feet high. Widespread outcrops may be seen in the anticline 2 miles east of Hot Springs, where the strata dips steeply to the west. It thins out rapidly north of Buffalo Gap and appears to be entirely absent in the canyon of Fuson Creek. It is thin at Cascade Springs and disappears a short distance to the west. 
An extended search has failed to detect any fossils in it, but it is of Lower Cretaceous age, as it lies below the Fuson shale.

\section{FUSON SHALE.}

The Fuson shale consists of fine-grained deposits lying between the Dakota and the Lakota sandstones and encircling the Black Hills. Its average thickness is about 65 feet, but it varies considerably and in general is thickest in the northern hills, although it is nearly 150 feet thick in Buffalo Gap. It is 100 feet thick southeast of Cascade Springs, but it thins westward to 30 to 60 feet and measures less than 50 feet in the Pass Creek region. It consists principally of a mixture of clay and fine sand and partly of tire clay, as a rule massively bedded. Some beds of sandstone are locally included. Its predominant color is white or gray, but in many places buff, purple, and maroon tints are conspicuous.

As the formation is relatively soft compared with adjoining sandstones, it usually forms a depression between a low crest of Dakota sandstone on the one hand and the higher summits of the Lakota sandstone on the other. Locally it is covered by talus from the sandstone cliffs above. One of its most extensive exposures is at the falls of Cheyenne River, where the section is as follows:

Section of Fuson shale at falls of Cheyenne River, south of Hot Springs.

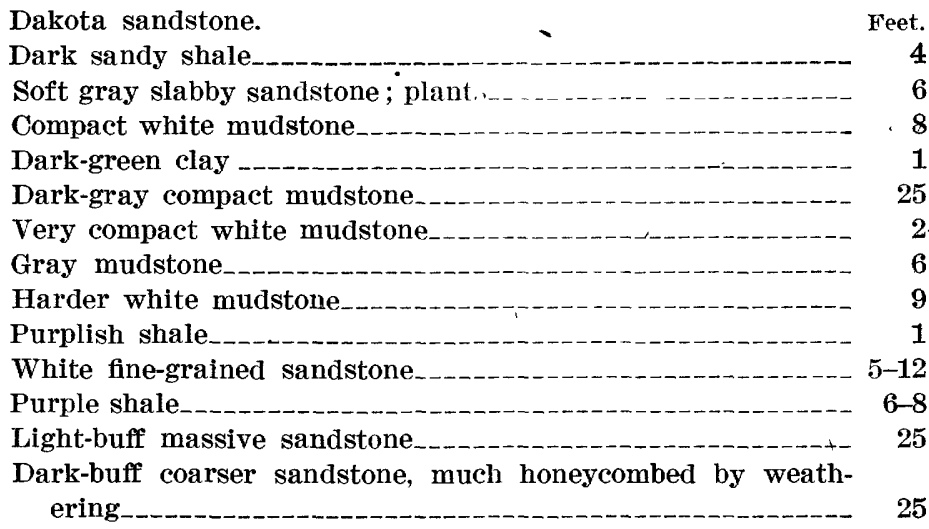

The formation is considerably obscured by talus along the canyon of Fall River but outcrops extensively in the side canyons, notably in one on the steep side of the anticline 2 miles due east of Hot Springs, where much of the material is bright purple and strongly resembles a shale that has been subjected to heat. Fuson Canyon affords some striking exposures of a portion of the formation in cliffs capped by Dakota sandstone. The uppermost bed is a moderately hard sandstone underlain by 10 feet of purplish-gray shales. 
10 feet of white mudstone, and 20 feet of bright-purple shale. On Dry Creek the formation is represented by 50 feet of white massive shale. On Squaw Creek the Lakota sandstone is overlain by about 50 feet of buff and purple shale, grading upward to the Dakota sandstone through several feet of shale and thin sandstone. Northwest of Hermosa shales of bright color prevail, much of the material being purple. Near Rapid City the formation is $\mathbf{1 0 0}$ feet thick, and near Sturgis 65 feet, but a few miles north of Sturgis it thickens to 100 feet or more and consists of white sandy beds of considerable hardness. On the south and north sides of the hills the formation is at many places mixed with considerable sand and sandstone. In the Hay Creek region it has yielded large numbers of fossil plants of Lower Cretaceous age.

\section{DAKOTA SANDSTONE.}

The formation here designated the Dakota sandstone is the uppermost member of the tripartite series formerly designated "Dakota sandstone" in the Black Hills region. It extends continuously around the uplift, but being rarely more than 100 feet thick it constitutes only a small part of the hogback ridge. Nevertheless it is conspicuous, because the foothills to which it usually gives rise slope steeply out of the adjoining valley or level plain formed by the Graneros shale. It consists mostly of gray sandstone, weathering brown, which is hard and massive below but thinner bedded above. South of Fairburn it is 150 to 200 feet thick and at Buffalo Gap 200 feet. (See Pl. VIII.) North of Edgemont it is in few places more than 150 feet thick. From Squaw Creek northward the sandstone thins to less than 50 feet at most places, and locally, south of Fort Meade, to less than 20 feet. Near Whitewood it is 50 to 60 feet thick and on Pass Creek 150 feet thick. The fossil impressions of dicotyledonous leaves dbtained from it are regarded as Upper Cretaceous in age.

\section{GRANEROS SHALE.}

The Graneros shale, the lowest formation of the Colorado group of early Benton age, extends entirely around the Black Hills uplift and is marked by lowlands and valleys. It consists of dark fissile shale 900 to 1,150 feet thick, the maximum being north of Belle Fourche and east of Sturgis. From Edgemont to Rapid City the average thickness is 900 feet.

In some areas the formation contains, toward its base, a thin layer of hard sandstone, which rises in a ridge of considerable prominence near Rapid City, Hermosa, Newcastle, and Belle Fourche. It occurs locally, but apparently at the same horizon, 150 to 300 feet above 
the Dakota sandstone. Its maximum thickness is about 30 feet. At Hermosa, where it is traceable for 4 to 5 miles, it is about 200 feet above the base of the formation and attains a thickness of 15 feet. At Rapid City and southeast of Sturgis it is again conspicuous 275 feet above the base of the formation. Near Belle Fourche it is thin, soft, and in places absent.

Next above this sandstone horizon is a series of hard gray shales known as the Mowry shale member. It is 150 to 200 feet thick and owing to its hardness gives rise to ridges of moderate prominence, many of which bear scattered pine trees. The shales of this member contain large numbers of fish scales and weather to a light silvery color, both characteristic features.

\section{GREENHORN LIMESTONE.}

One of the most prominent features in the plains immediately adjoining the Black Hills is a low but distinct ridge or escarpment, which is due to a hard limestone bed in the middle of shales of Benton age. It usually lies 1 to 4 miles from the hogback ridge of the Dakota sandstone and faces toward the hills. It is thin but persistent and is characterized by many impressions of Inoceramus labiatus, a fossil of rare occurrence in the adjoining formations.

The Greenhorn limestone contains a considerable amount of clay and fine sand. It gains hardness on weathering, for in the outcrops it breaks into hard, thin, pale-buff slabs covered with impressions of the distinctive fossil. Its thickness averages about 65 feet. At its base it is usually distinctly separated from the dark Graneros shale by abrupt change in material (see Pl. IX); and in its upper portion it appears to grade into the Carlile shale through 6 or 8 feet of passage beds.

The most extensive exposures of the Greenhorn limestone are in the prominent escarpments which rise high above the slopes west and northwest of Edgemont along the south side of Cheyenne River. Owing to the low dip the limestone is spread out in plateaus which extend for some distance back from the edge of the escarpment. In the region about Fairburn the formation is traversed by a syncline, which spreads it out into a bifurcated ridge south of the town. On the adjoining divides, notably in those between French Creek and Battle Creek and between Battle Creek and Spring Creek, the formation is buried beneath the overlapping White River deposits. It is well exposed in the banks of Battle Creek $1 \frac{1}{2}$ miles below Hermosa, where, in its only slightly weathered condition in the fresh stream cut, it is seen to be a hard calcareous light-gray shale filled with Inoceramus. East of Sturgis it constitutes a ridge extending to Bear Butte. In the northern Black Hills it is conspicuous about Belle Fourche, notably in a prominent butte known as Susie Peak. 


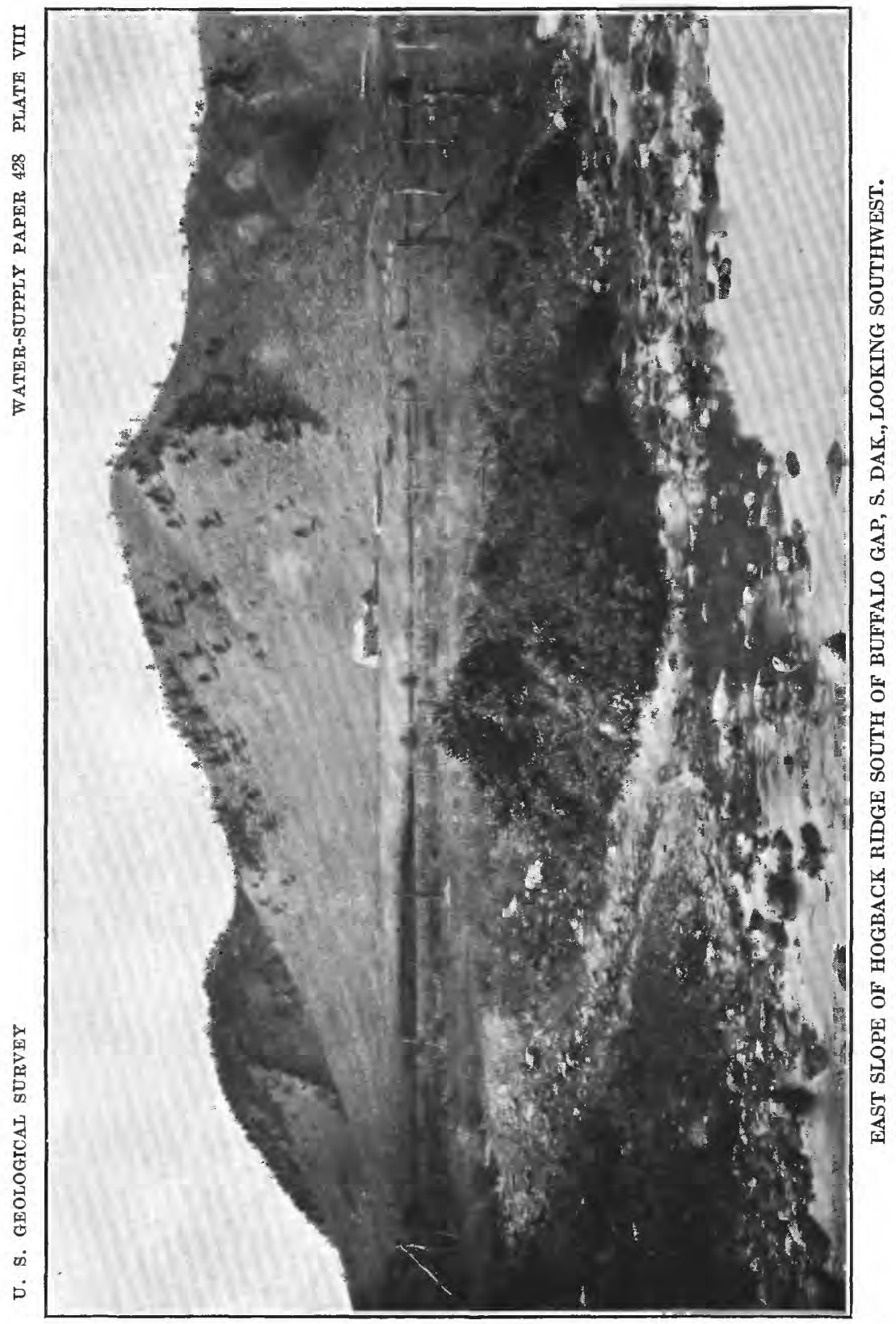




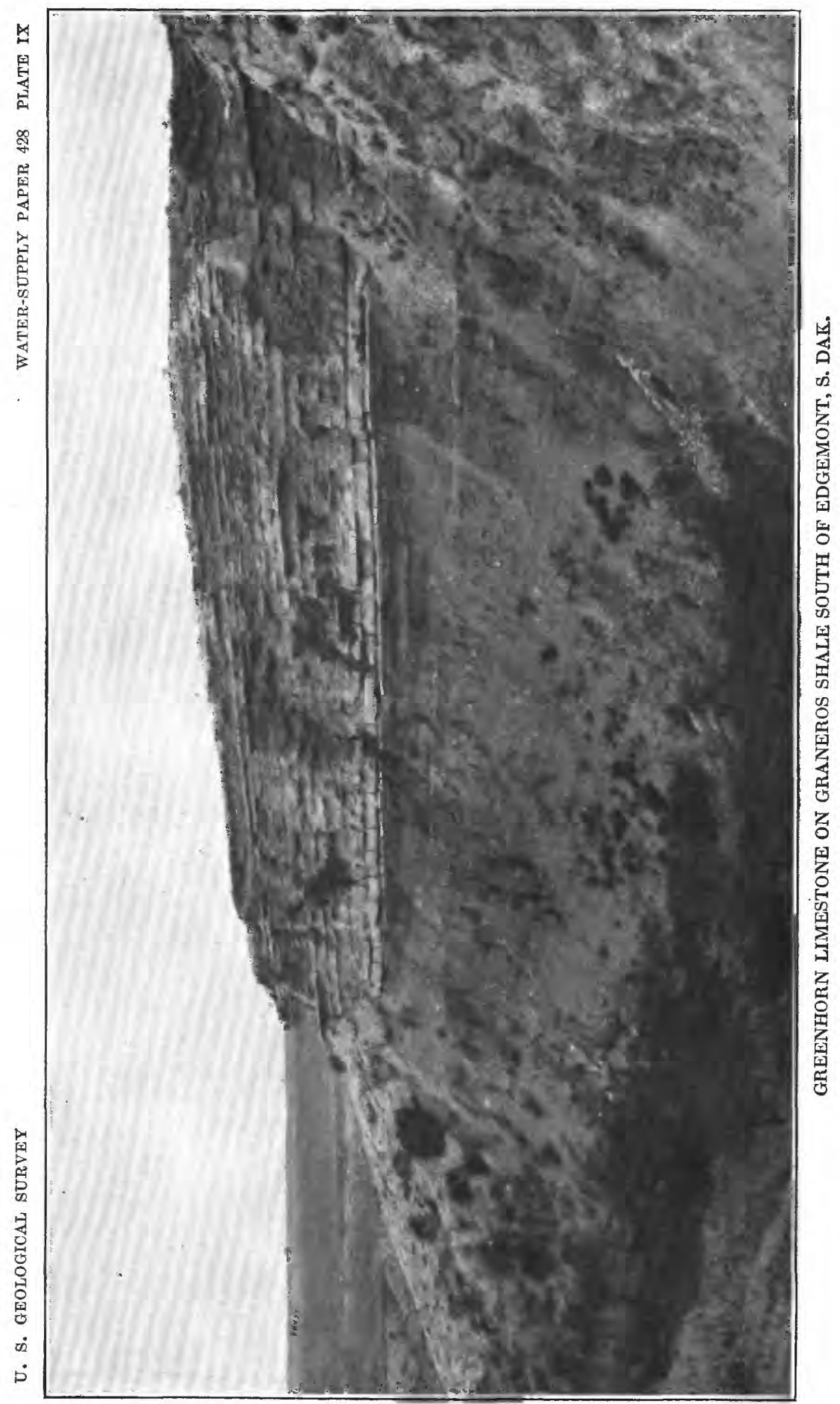




\section{CARLILE SHALE.}

The Carlile shale, the uppermost formation of Benton age, consists of dark fissile shale that contains concretions, thin sandstones, and impure limestone layers lying between the Greenhorn limestone and the Niobrara formation. Near the top of the formation numerous oval concretions contain Prionotropis, Prionocyclus, and other fossils. The thickness ranges from 500 to 600 feet, except in the region north of Belle Fourche, where it is locally slightly more than 750 feet. Some typical sections follow:

\section{Section of Carlile shale near Buffalo Gap.}

Niobrara formation.

Feet.

Shales, with large buff concretions

150

Hard, slabby sandstone.

2

Gray shale 130

Thin coarse sandstone

Gray shale_._._. 75

Concretions in gray shale

Gray shale_-_._- 40

Calcareous sandstone with Ostrea and other fossils_._._._._. 4

Shale and talus_._- 180

Greenhorn limestone.

Section of Carlile shale $1 \frac{1}{2}$ miles southeast of the falls of Cheyenne River.

Niobrara formation.

Feet.

Gray shale, with large buff concretions_-_____- 50

Gray shale_-_._-_._. 70

Light-gray sandstone

Dark-gray shale, with thin sandy layers__________._. 160

Sandstone___._._.

Gray shales_-_-_- 150

Greenhorn limestone.

NIOBRARA FORMATION.

The calcareous deposits of the Niobrara formation completely encircle the Black Hills, presenting distinctive features throughout. The terial is a soft shaly limestone or impure chalk, containing greater or less admixture of clay and fine sand. In unweathered exposures it is generally light gray, but its weathered outcrops have a bright-yellow color which usually renders them conspicuous, although, owing to the softness of the materials, they form few noticeable ridges. The thickness of the formation is about 225 feet in the central and southern Black Hills and 150 to 200 feet on the northern slopes. At many places it includes thin hard layers of shells of Ostrea congesta, a fossil distinctive of the formation. A few hundred feet of dark overlying shales may also belong to this formation. 
Many thousand square miles of the country adjoining the Black Hills are occupied by the Pierre shale, a thick mass of dark shale, weathering light brown and relatively uniform in composition throughout. It gives rise to a dreary monotony of low rounded hills, sparsely covered with grass and not very well adapted to agriculture. The thickness of the formation, so far as it can be ascertained, is 1,200 feet, but owing to the gentleness of the dip it can be measured at only a few places. Fortunately it has been found that the formation includes, about 1,000 feet above its base, scattered lenses of limestone containing numerous shells of Lucina occidentalis. Most of these lenses occur at a definite horizon, and in places, where they occupy the surface over a wide area, they indicate the attitude of the formation and permit estimates to be made as to the depth of the Dakota sandstone in the shale region adjoining the Black Hills.

The limestone concretions carrying Lucina range from 2 to 20 feet in diameter and from 6 to 8 feet in thickness and are commonly of irregular lens shape. Owing to their hardness these lenses, when uncovered by erosion, give rise to low conical buttes resembling very squat tepees (see Pl. XI), and accordingly they have been designated "tepee buttes," a term used for similar forms in the Pierre shale of southeastern Colorado. Large numbers of them rise 10 to 150 feet above the surrounding slopes in the vicinity of Oelrichs, east of Hermosa and Sturgis, and in the Willow Creek valley east and north of Newell. Horizontally the lenses occur at irregular intervals, so that the buttes are scattered very irregularly and some of them are separated by many miles.

Numerous concretions occur in the Pierre shale at various horizons and usually contain many distinctive fossils. Baculites compressus, Inocercamus sagensis, Nautilus dekayi, Placenticeras placenta, and Heteroceras nebrascensis are the more abundant, and Lucina occidentatis is found here and there. The most fossiliferous beds are in the upper part of the formation. The concretions are generally small and calcareous and break into brown pyramidal fragments which are scattered more or less thickly all over the-Pierre surfaces.

In the southern part of the Black Hills region a very distinctive series of black splintery, fissile shales, containing three beds of concretions but no fossils, lies at the base of the formation. These shales have been mapped with the Pierre but may be Niobrara. They are about 150 feet thick in the Edgemont-Oelrichs region, where they give rise to a steep slope, in places rising conspicuously above the lowlands in the Niobrara chalk. 
WHITE RIV̧̨R GROUP.

Extensive areas of clay, sand, and gravel of the White River group cover some of the plateaus along the foot of the hogback ridge from a point near Rapid City to a point 15 miles southwest of Fairburn, and small remnants occur at various other points along the higher slopes of the Black Hills, notably at Lead, Maitland, and west of Argyle. The deposit forms a thick mantle on the divides between Spring and Battle creeks, Battle and French creeks, and French and Beaver creeks. Extensive masses occur in the Red Valley south of Rapid City and west and southwest of Hermosa, and some of these overlap westward through old valleys into the limestones and granites. The maximum thickness is 300 feet. -

The formation consists of fuller's earth, sand, limestone, and calcareous grit; and the courses of old channels are marked by coarse gravel, in places cemented into hard conglomerate by silica or by calcium carbonate. The principal material, especially of the upper beds (Brule clay), is a porous crumbling clay, pale flesh color when dry but light brown when damp. Some portions are very pale green when dry and olive-colored when wet. Much of this fine-grained deposit is fuller's earth. These beds form badlands in many places. The lower beds (Chadron formation) are mostly coarse and, in the vicinity of Hermosa, consist of a coarse sandstone and a dark conglomerate. About Fairburn and to the west there are extensive channels filled with conglomerate of limestone pebbles in a limy matrix. On the higher lands northwest of Hermosa some beds of massive limestone are included that are in places 30 feet thick. Coarse material of White River age is extensively exposed in railroad cuts through the divide south of Fairburn, where the sands are crossbedded. The White River deposits contain many bones of animals typical of the Oligocene.

\section{STRUCTURE.}

\section{GENERAL FEATURES.}

The general monocline formed by the strata dipping away from the central area of crystalline rocks of the Black Hills is interrupted by several local flexures and by many changes in the rate and direction of dip. A few faults exist, and the Bear Butte and other igneous masses break and flex the beds. An understanding of the structure of the beds is of the greatest importance in considering the underground-water problems, especially in determining the depth of the water-bearing sandstones. The principal structural features affecting the artesian conditions are shown in seven sections (see $\mathrm{Pl} . \mathrm{X}$ ), whose location is indicated on the map ( $\mathrm{Pl}$. I, in pocket). 


\section{IIMESTONE RIDGE.}

Except in the northern slope of the hills, where many minor flexures and considerable deformation have been caused by igneous intrusion, the thick sandstones and limestones of the Limestone Ridge dip away from the central area in a general monocline. On the west slope of the uplift the dips are low and the outcrop areas form a broad plateau, which, however, narrows somewhat as the dips steepen slightly west and southwest of Pringle (see sections 6 and 7) and along the east slope from Wind Cave to Rapid City, where the dips are $10^{\circ}$ to $20^{\circ}$. In places the outcrop zone narrows to a steep ridge. (See sections 4, 5, and 6, Pl. X.) Northwest of Rapid City the dips diminish and the limestone plateau widens, but in the vicinity of Piedmont and Sturgis the dips along the east slope of the limestone belt are steep. A marked local arch in the beds 3 miles northwest of Rapid City is shown by the Minnekahta limestone.

\section{ANTICLINE AND SYNCLINE OF WHITEWOOD REGION.}

Northwest of Sturgis a prominent arch rises on the limestone slope and extends to Crook, beyond which it crosses the Red Valley and causes a notable projection of the hogback ridge southeast of St. Onge. The further extension of this arch northward is well marked in the shale region about Haystack Butte, and in Susie Peak it causes a great deflection in the outcrop and ridge of Greenhorn limestone. The arch is therefore an important feature of the artesian problem, lifting the water-bearing sandstones several hundred feet in the region east of Belle Fourche.

West of this anticline is a syncline (see sections 2 and $3, \mathrm{Pl} . \mathrm{X}$ ), which holds Spearfish red beds in Boulder Park and down the valley to Crook and causes the southward deflection of the'Lakota and Dakota sandstones in the hogback ridge west of Whitewood. It also underlies the shale valley followed by the railroad at St. Onge and extends north a short distance east of Belle Fourche, where the waterbearing sandstones descend more than 900 feet below the surface.

\section{RED VALLEY IN SPEARFISH REGION.}

In Centennial Prairie and the Red Valley about Spearfish, in a very broad area of northerly and northeasterly dips; the strata are nearly horizontal in places and rarely show noticeable dip. At Elkhorn Peak these beds are sharply arched by a dome bringing up a small circular mass of Minnelusa sandstone. 
BEAR BUTTE.

Bear Butte, northeast of Sturgis, is due to an igneous intrusion which has faulted up a large mass of Pahasapa and overlying strata on its east and northeast sides and which exposes the red beds of the Spearfish formation in a dome on its west slope. The disturbance of the beds is very great but relatively local, affecting an area 6 miles long from west to east and 3 miles from north to south, on all sides of which the usual monoclinal structure continues.

\section{HOGBACK RIDGE AND RED VALLEY SOUTH OF STURGIS.}

From Sturgis for many miles southward the Red Valley and the hogback ridge present great uniformity of structure with general dip to the east. (See sections $3,4,5$, and 6, Pl. X.) Many variations in rate occur from place to place, and northeast of Piedmont and southwest of Fairburn there are small branch anticlines in the Dakota and associated sandstones. A small anticline in limestone and red beds lies northwest of Rapid City (p. 24), and another small anticline in the Greenhorn limestone and associated shales lies just south of Fairburn.

Along the hogback ridge the dips are moderately steep, near Sturgis $12^{\circ}$ to $15^{\circ}$, but they diminish to the south and in the shale area to the east. On the east slope of Piedmont Butte the Dakota sandstone dips $4^{\circ}$, on Elk Creek $8^{\circ}$, and on Rapid Creek $22^{\circ}$. On the west side of the anticline southeast of Piedmont a local dip of $60^{\circ}$ is exhibited. East of Rapid City the Greenhorn limestone dips $10^{\circ} \mathrm{E}$., a slope considerably steeper than in the region to the north and the south. Along the outcrop zone of the Carlile and Niobrara formations dips of $2^{\circ}$ to $3^{\circ}$ are numerous and some of $5^{\circ}$ or $6^{\circ}$ are found.

From Spring Creek southward past Hermosa the Red Valley and hogback ridge have no notable structural features, the strata dipping $5^{\circ}-12^{\circ} \mathrm{E}$. in a uniform monocline. On Squaw Creek the Dakota sandstone dips $9 \frac{1}{2}^{\circ} ; 5$ miles northwest of Hermosa $10^{\circ}$. On the divide south of Spring Creek the Red Valley is filled with White River deposits for some distance, and these also partly bury the hogback ridge. In the southeast corner of T. $3 \mathrm{~S}$., R. $7 \mathrm{E}$., 8 miles southeast of Hermosa, the Dakota sandstone presents a small syncline and anticline in the midst of the White River beds.

\section{PASS CREEK REGION.}

In the region west of Minnekahta and north of Argentine the formations dip southwest at very low angles and are exposed in broad outcrops. Near the junction of Hell Canyon and Pass Creek a low irregular dome in the Red Valley widens the outcrop of Spear- 
fish red shale and gives rise to an outlying ridge of Minnekahta limestone. Where the dome is cut through by 'Tepee and Hell canyons the top of the Minnelusa sandstone is revealed. A small minor dome brings up the Minnekahta limestone in a small knoll just north of the mouth of Hell Canyon. It is due in part to the influence of this doming that the hogback ridge has a crescentic course on either side of Pass Creek Canyon. On the north side of the canyon is Elk Mountain, in which the strata dip $10^{\circ}$ to $25^{\circ} \mathrm{W}$. In the ridge east of the creek the dips are low and give rise to a wide southward-sloping plateau of Lakota and Dakota sandstones.

PLAINS EAST OF THE BLACK HILLS.

The representation of the structure of the plains east of the Black Hills in cross sections 2 to $6(\mathrm{PI} . \mathrm{X})$ and the determination of the depth to the Dakota sandstone as shown on the map (Pl. I, in pocket) are based largely on the relation and distribution of the Greenhorn limestone, Niobrara formation, and the tepee buttes in the Pierre shale. It is believed that the principal horizon of the limestone concretions causing these buttes is about 1,000 feet above the base of the Pierre shale. The region is one of low dips, the rate of inclination gradually diminishing toward the east.

In portions of the outcrop zone of the Graneros shale and the Greenhorn limestone the strata dip $5^{\circ}$ to $10^{\circ}$; in the Niobrara area they rarely dip as much as $5^{\circ}$; in the area southeast of Hermosa they dip less than $2^{\circ}$. In the Pierre area the dip is difficult to determine in surface outcrops of the shale, but the general structure is indicated by the tepee buttes. It is found that the strata are nearly horizontal a few miles east of Buffalo Gap and bend into a shallow syncline on Cheyenne River about Mohler post office. On Battle Creek they slope eastward about 250 feet to the mile, gradually steepening to about 400 feet in the region east of Brennan. Northward about Bend post office the dip decreases again to 125 feet to the mile. North and northwest of Alkali post office the strata are nearly horizontal, but they rise in a long, low anticline along Belle Fourche River and probably in a faint anticline northeast of that stream.

\section{UNDERGROUND WATER.}

\section{GENERAI CONDITIONS.}

The slopes of the Black Hills and the plains adjoining them are underlain by 6,000 feet of sedimentary rocks, including several thick beds of water-bearing sandstone which receive their water supplies from rainfall on the higher ridges and slopes. The principal beds are the Lakota and Dakota sandstones, Minnelusa sandstone, and 
Deadwood sandste, , These sandstones pass underground in consequence of the general net i dip on the sides of the uplift, and therefore in the adjoinin "

Northern

Sou

Black Hills

\section{Black Hills}

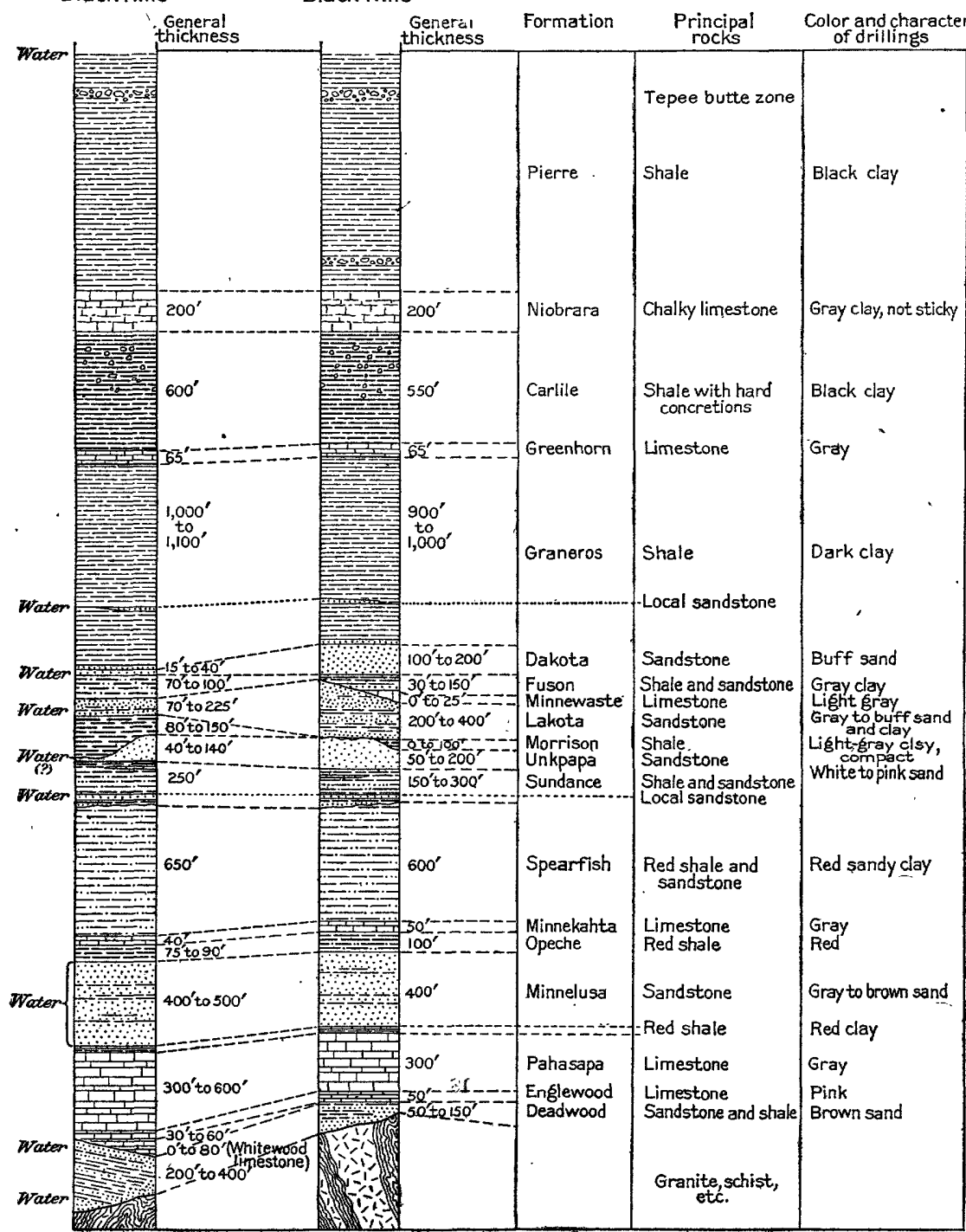

FIGURE 1.-Columnar sections of rocks in the Black Hills and vicinity, showing thickness of beds, relation of water-bearing sandstones, and color of drillings.

under a thick body of relatively impermeable shales. The steep dip along the foothills (see p. 25) carries them to a considerable depth, but in most portions of the foothills and plains one or more of them 
are within reach of the well borer. As this region is somewhat arid, with surface waters inadequate or of bad quality in most localities,

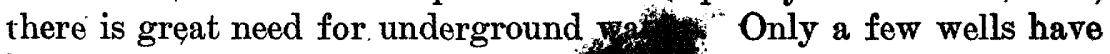
been sunk, but most of these have so satisfactory that they greatly encourage drilling for large water supplies throughout the region. The relations of the water-bearing beds in the succession of sedimentary rocks in the Black Hills region are shown in figure 1. The principal water-bearing sandstones rise to the surface on the slopes of the Black Hills in regular order, as shown in the cross sections. (See Pl. X.) They crop out in wide zones encircling the uplift, and receive a large amount of water not only from the rainfall on their surface but from streams, which at many localities sink into them wholly or in part in crossing their outcrops. This sinking is observed in almost every valley leading out of the central area. Few of the streams carry into Belle Fourche or Cheyenne River more than a small portion of the original run-off of their drainage basins, for much of it sinks underground in crossing the Minnelusa, Lakota, and Dakota sandstones. The water thus absorbed by the sandstone passes far beneath the surface as the water-bearing beds descend the slopes of the uplift. Water also passes underground in caves and crevices in the limestone, some of it coming out again in springs and some of it sinking into underlying sandstone. (See PI. XII, A.)

Some of the artesian water also leaks to the surface in springs, as in the warm springs at Hot Springs, at Cascade Springs (Pl. XII, $B$ ), and in the upper part of Buffalo Gap. This warm water comes from a considerable depth.

\section{DEPTHS TO ARTESIAN WATER.}

The depths to the water-bearing sandstones (see map, Pl. I, in pocket, and sections, $\mathrm{Pl}$. $\mathrm{X}$ ) have been ascertained by careful measurements of the thickness of the several formations at many places throughout the Black Hills and adjoining plains. The structure and distribution of these formations have been considered in preparing the underground-water maps of the region. An important guide to the structure in part of the plains is furnished by the horizon of limestone lenses in the Pierre shale that give rise to tepee buttes. (See Pl. XI.) The thickness of the beds differs somewhat from place to place in the outcrops and doubtless varies underground, especially in the lower sandstones and limestones, which show a general thinning to the east. (See fig. 2.) These older rocks are absent under central-eastern South Dakota and the position of their eastern margins has not been ascertained. 


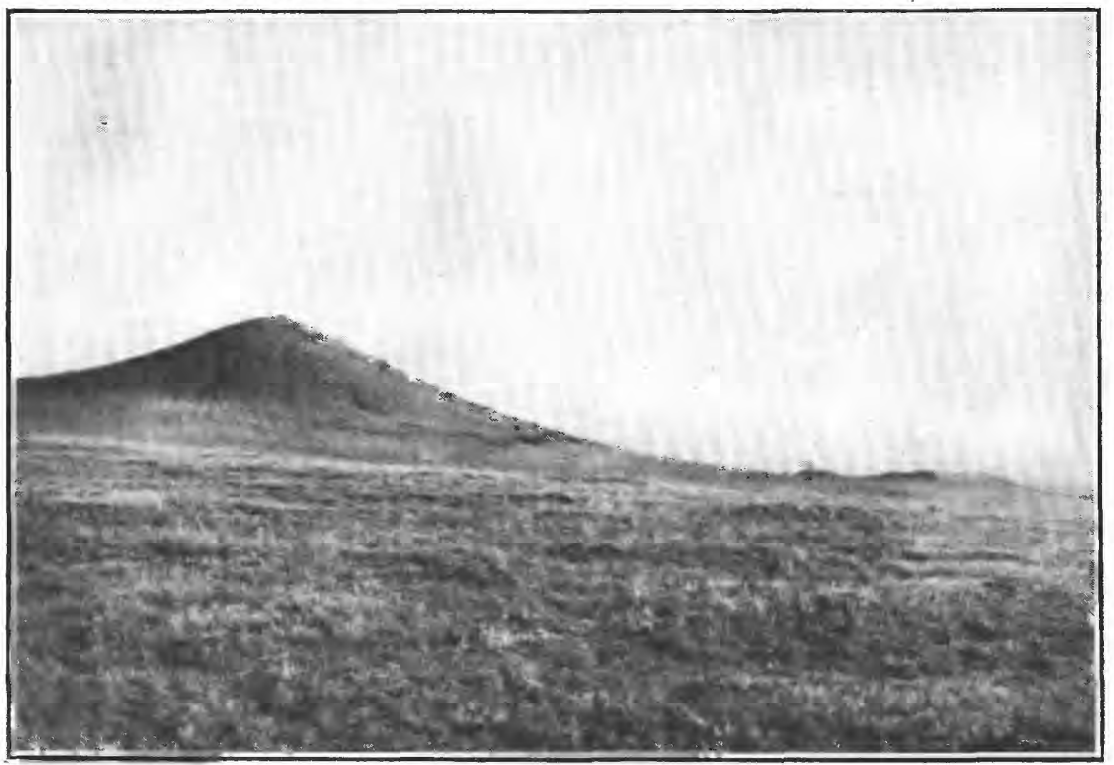

A. GROUP OF TEPEE BUTTES.

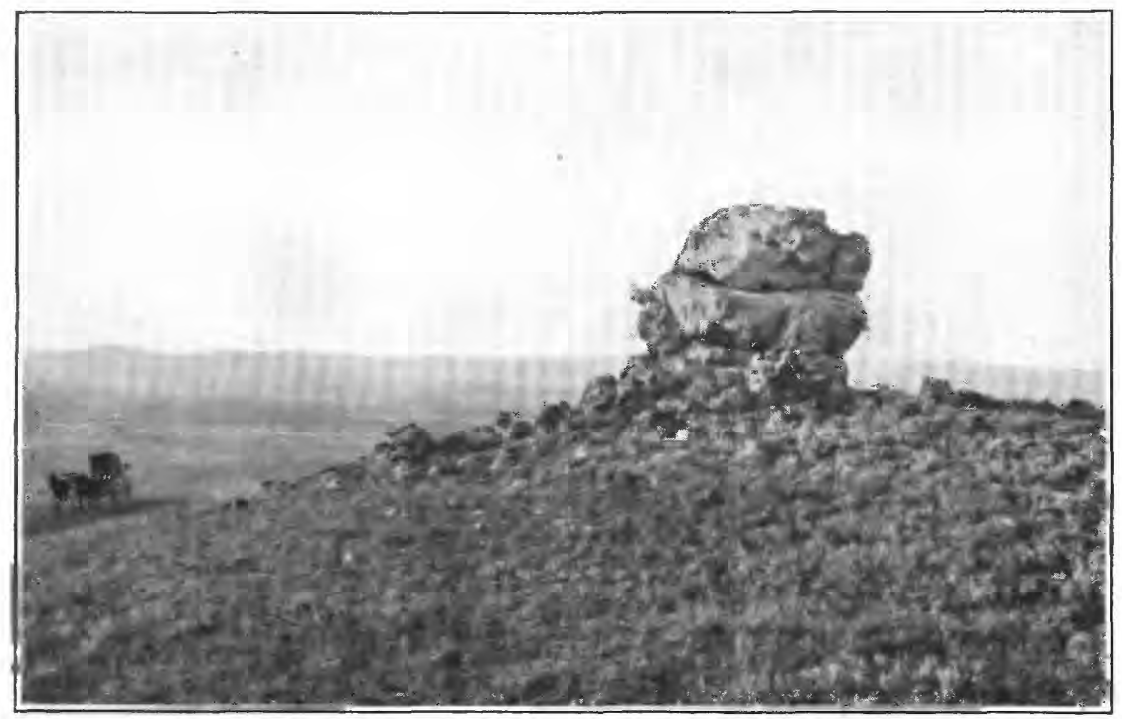

B. LIMESTONE CORE SUCH AS CAUSES TEPEE BUTTES.

TEPEE BUTTES DUE TO LIMESTONE LENS IN PIERRE SHALE. 


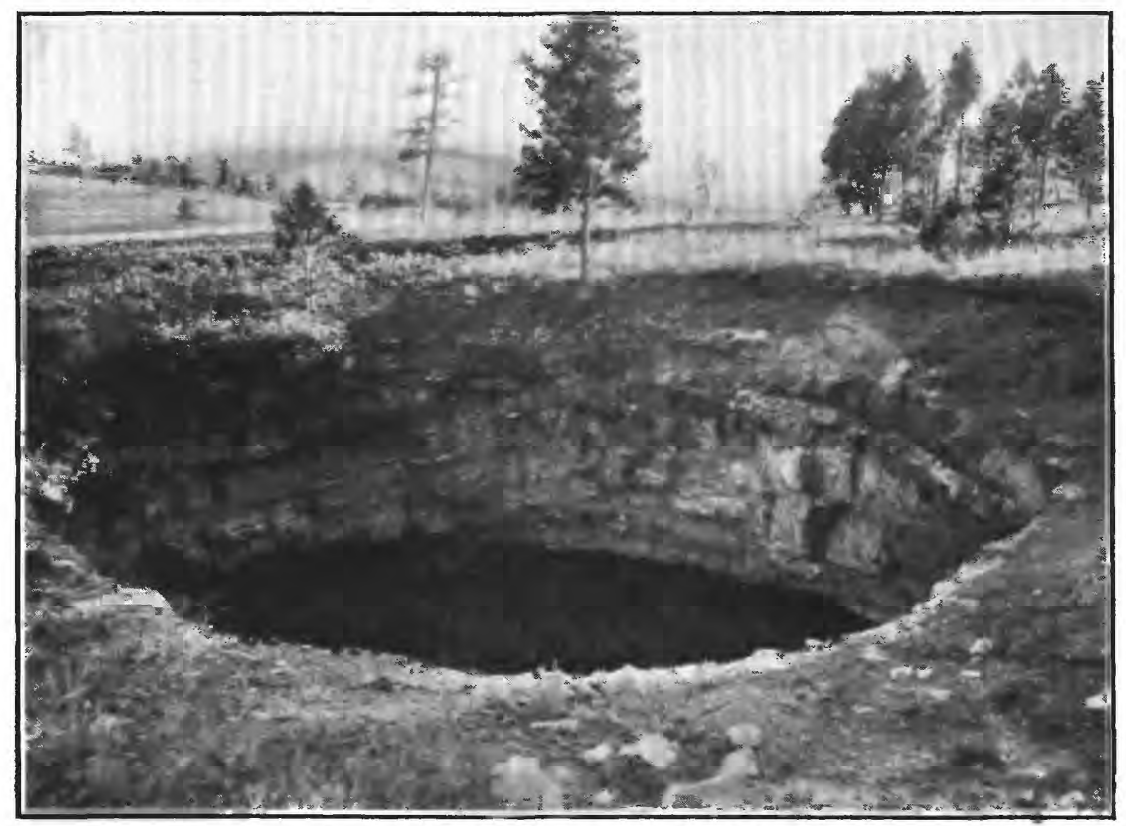

A. SINK HOLE IN MINNEKAHTA LIMESTONE.

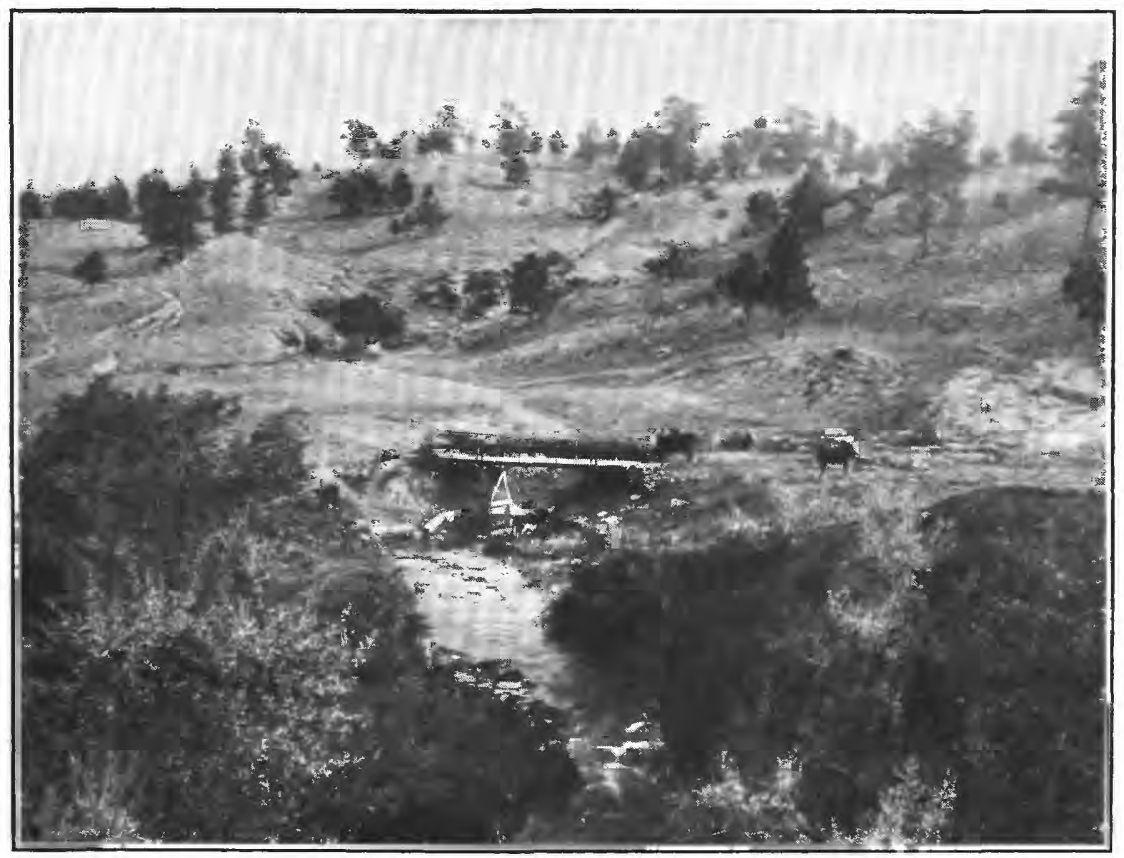

B. SPRING AT CASCADE SPRINGS, S. DAK. 


\section{WATGR-BEARING SANDSTONRB.}

\section{DAKOTA AND LAKOTA SANDSTONES.}

The Dakota and Lakota sandstones are the principal beds in which artesian water is to be expected in the wide area of plains adjoining: the Black Hills. The greatest volume of water is in the Lakota sandstone, but in some districts the Dakota sandstone contains a moderate supply.

Both sandstones outcrop in a wide zone in the hogback ridge, where by direct absorption and by the sinking of water from streams they receive a considerable proportion of the rainfall. This water flows slowly through the permeable sandstones and finally passes far below the surface of central South Dakota and emerges in great springs and general seepage in the outcrops of Dakota sandstone in the Missouri Valley in the southeastern corner of the State.

As the water enters the Dakota and Lakota sandstones in land mostly from 3,100 to 3,500 feet above sea level and passes in them beneath a thick body of relatively impermeable shale, it should be expected to have great pressure or head in the plains to the east, which finally slope down to 1,200 feet above sea level near Missouri River. This pressure, which is found in many wells in central and eastern South Dakota, is conclusive evidence that the water flows underground for many hundreds of miles. Some wells show surface pressures of 175 to 200 pounds to the square inch, the 200 pounds indicating a pressure of 780 pounds to the square inch at the bottom of the well. Such pressures can be explained only by the hydrostatic influence of a column of water extending to a high altitude on the west. There, is, howerer, considerable escape of water from the Dakota'sand-

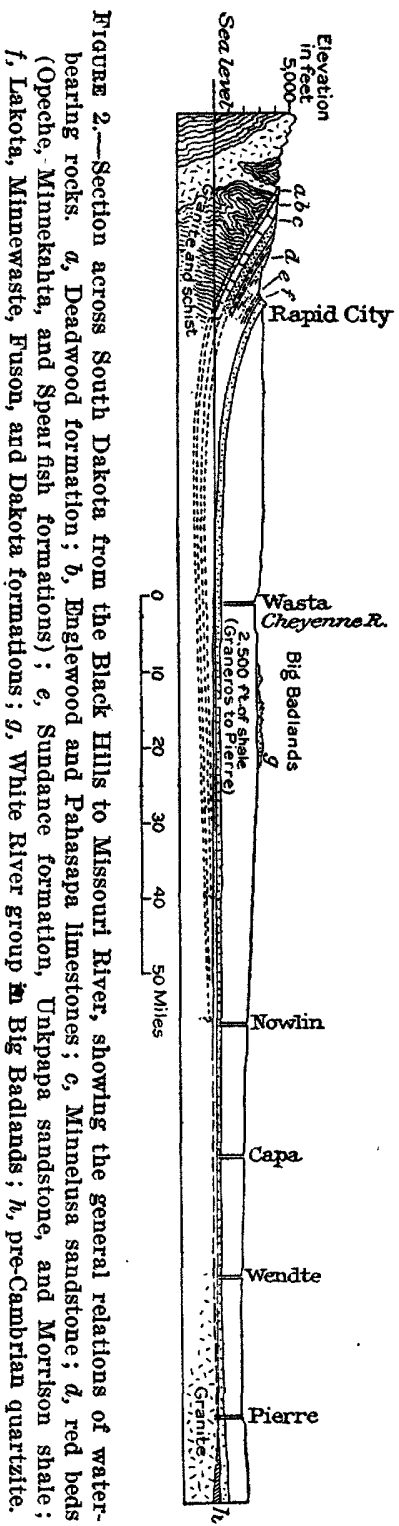
stone in its outcrops in the Sioux City region and southward, and some must seep through the overlying shale, so instead of 
the original head of the intake being sustained there is gradual diminution to the east and it dies out in the outcrop zone. There is therefore a grade in the head or altitude to which water can rise, a slope sustained by the friction or slowness of passage of water through the strata. A simple apparatus (see fig. 3) illustrates conditions closely similar to those in the Dakota and Lakota sandstones, which are the principal water-bearing strata under the Great Plains. The accompanying cross section (fig. 4) shows the head observed along a line from the intake zone west of Rapid City to the outlet in the Sioux City region.

From the altitude of the outcrop of the Dakota sandstone and the pressures observed in wells in central and eastern South Dakota, contour lines (see fig. 5) have been constructed to indicate the head of artesian water in the State, and it is on this basis that the " head" lines have been spaced on the map ( $\mathrm{Pl}$. I, in pocket). The spacing of these lines necessarily is in part theoretical, but they are required in delimiting the flowing from the nonflowing areas.

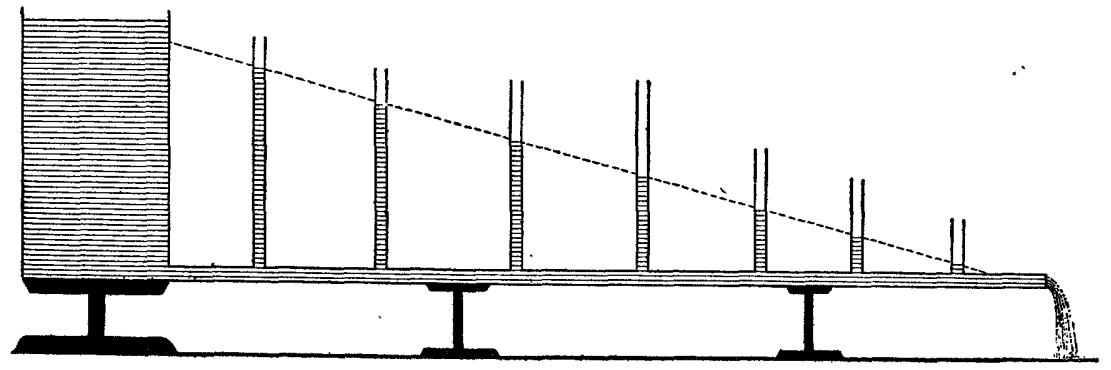

Figure 3.-Apparatus for illustrating the declivity of head of liquid flowing from a reservoir. The shaded portions are water.

This diminution of head (termed hydraulic grade) is shown on the map by lines indicating the height, at intervals of 100 feet, to which the underground water may be expected to rise above sea level. These lines also afford a means for estimating the pressure of the water in the area of flow, the pressure in pounds' at any point being ascertained by subtracting the altitude of the land from the altitude of the head and dividing by 2.3 (the height in feet of a column of water 1 inch square, weighing 1 pound). The depth below the surface at which water would stand in a well in the area too high for a flow may be found by subtracting the altitude of head from the altitude of the land, as shown by the brown contour lines on the base map. The interval of these contour lines is 100 feet. Intermediate figures for both may be obtained by estimating proportionate distances between the lines. For instance, at Smithwick, which has an altitude of 3,225 feet and is not far above 
the 3,100-foot line of head, the water should be expected to rise within about 100 feet of the surface, and, as is shown by the pattern indicating depths, it would be necessary to sink a well about 2,400 feet to reach the top of the Dakota sandstone. It is possible that it might be necessary to sink 150 to 200 feet deeper through the Fuson shale and Minnewaste limestone into the Lakota sandstone before a large volume of water could be obtained.

The areas in which the head of water is sufficient to afford surface flow and areas in which a flow is not available are shown in different colors. The areas of flow as deduced from the calculated head of the water comprise the valleys of Cheyenne River, Beaver, Lame Johnny, French, Dry, Battle, Spring, Rapid, Box Elder, Elk, Alkali, Bear Butte, Volunteer, Whitewood, False Bottom, Hay, Elm, and Willow creeks, and Belle Fourche River, but, owing to lack of precise data in most of the region, the limits are only approximate. It will be noticed that the altitudes to which the water may be expected to rise decrease regularly toward the east, for it is in that direction (away from the source of supply) that the altitude of head gradually diminishes.

The water from the Dakota and Lakota sandstones is the source of supply for numerous wells 400 to 2,000 feet deep. which furnish large volumes of water in eastern and central South Dakota and about Belle Fourche, and it is believed that this water is also available under the extensive plains lying immediately east of the Black Hills. On the map (Pl. I, in pocket) the depths to the top of the Dakota sandstone are shown

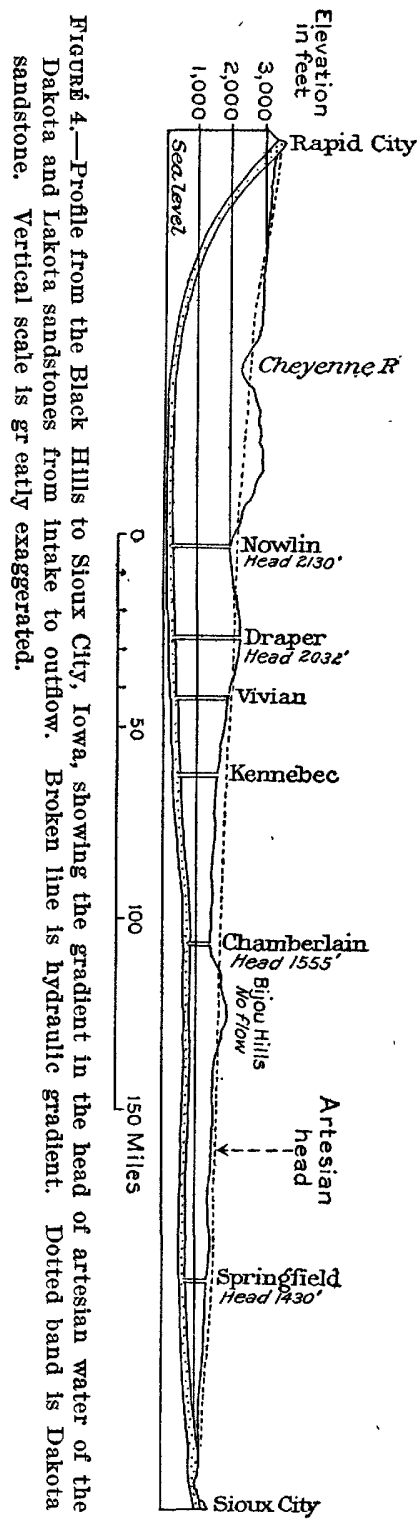
by patterns in color, each of which includes between its limits a difference of 500 feet; thus, one represents depths less than 500 feet, the next from 500 to 1,000 feet, and so on. 
On the columnar section (fig. 1, p. 27) are shown the beds which have to be penetrated in drilling. These can be recognized by their characteristics and relations as shown in this section and described in the table (p. 9). Two fossils, Ostrea congesta and Inoceramus labiatus (Pl. XIII), are important guides in determining the identity of two prominent formations which underlie the plains area. The Ostrea congesta occurs crowded together and constituting thin shelly layers in the upper portion of the Niobrara chalky shale, which although bright yellow when exposed on the surface, is pale bluegray when first brought out by the well boring. The Inoceramus is characteristic of the Greenhorn limestone, which is hard and

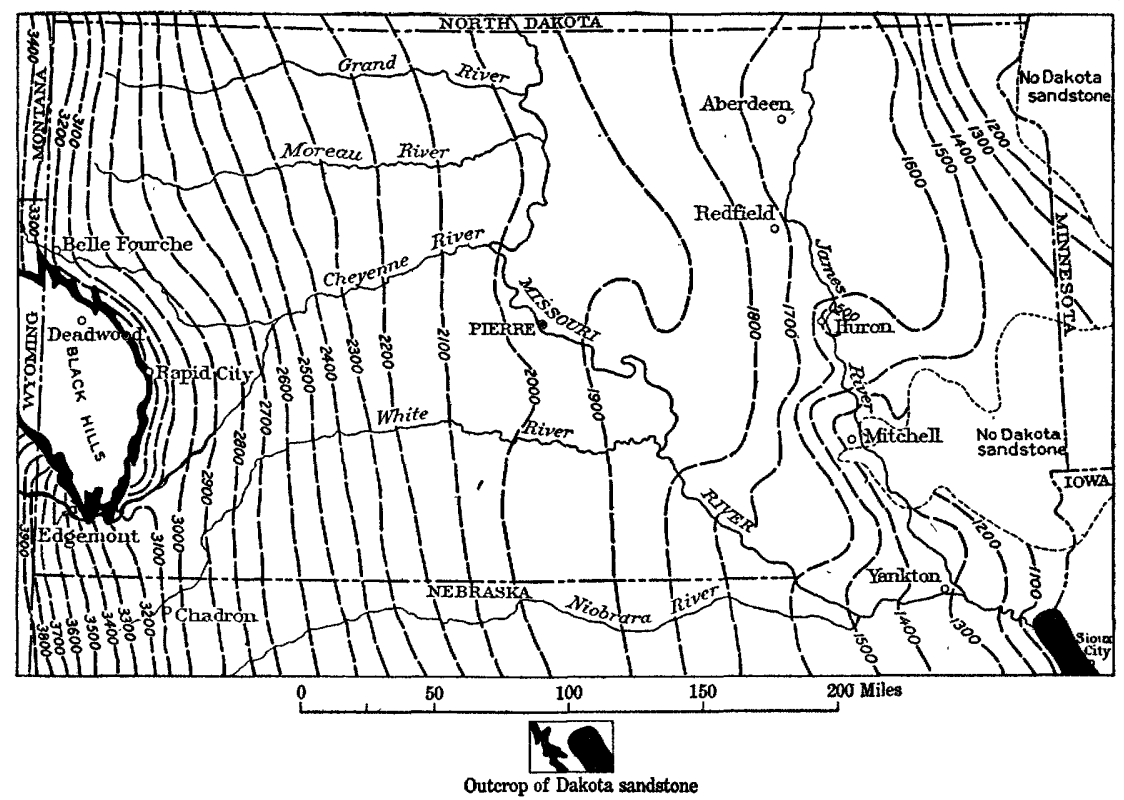

FraURE 5.-Outline map of South Dakota showing hydraulic gradient by contour lines of head.

buff-colored on the surface, as seen in the many outcrops in the escarpment just east of the hogback ridge, but is dark gray and soft textured underground. The zone of concretions and the thin layers of sandstone in the Carlile shale will be encountered by the well borer and recognized by their hardness and their relations to adjoining beds. (See fig. 1, p. 27.)

\section{FORMATIONS BETWEEN THE LAKOTA AND MINNELUSA SANDSTONES.}

In the Morrison and Sundance shales underlying the Lakota sandstone there are no prospects for water, but in the sandstone members in the lower portion of the Sundance formation there is a small 

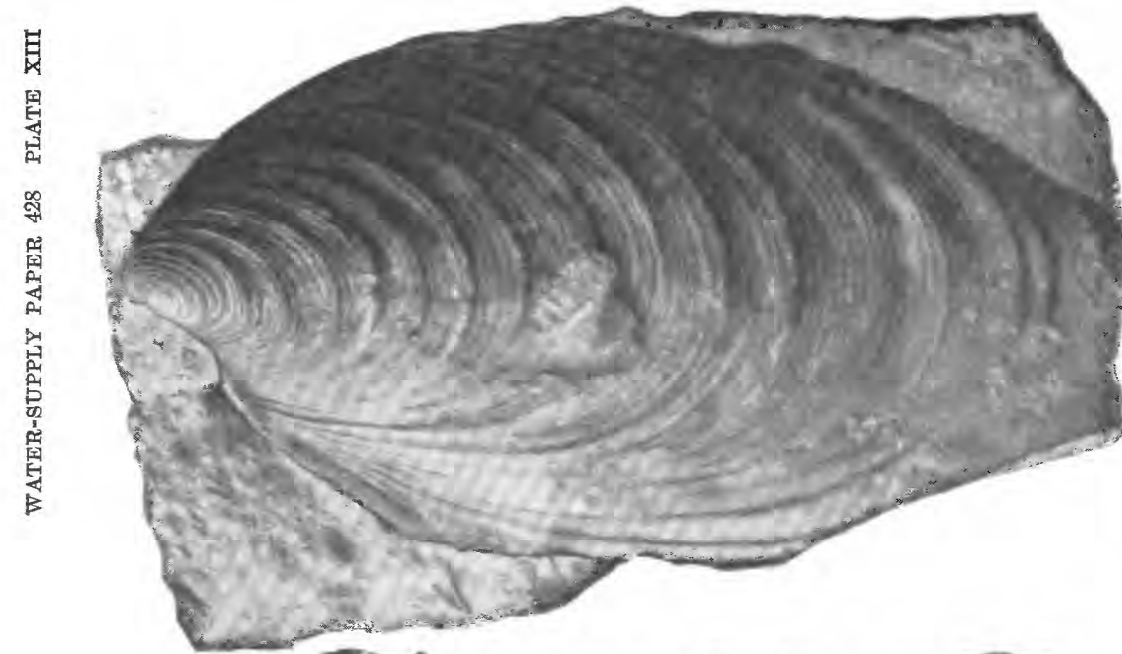

ต่

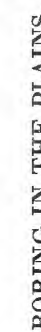

要

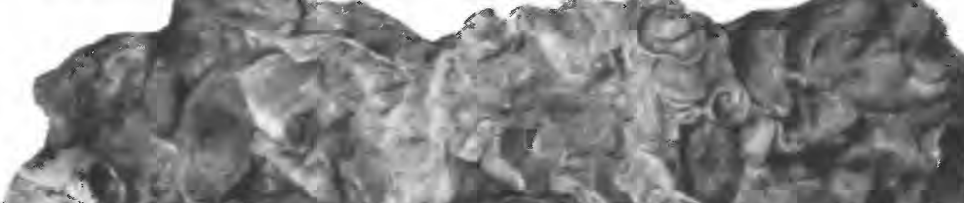

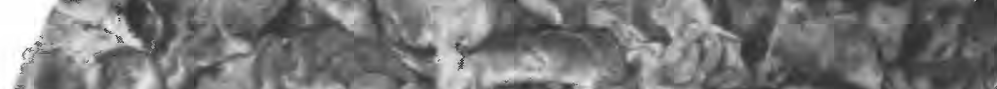

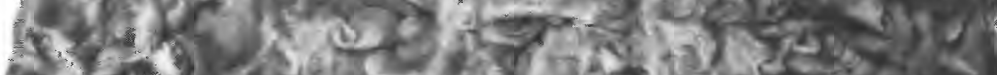

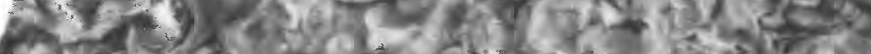

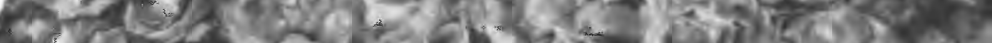

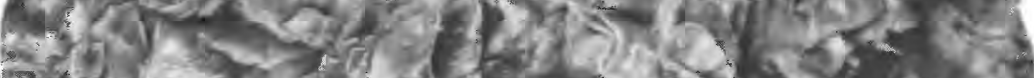

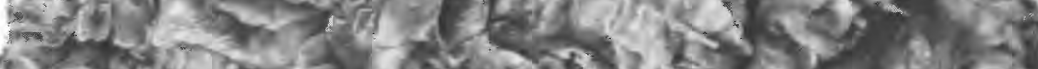

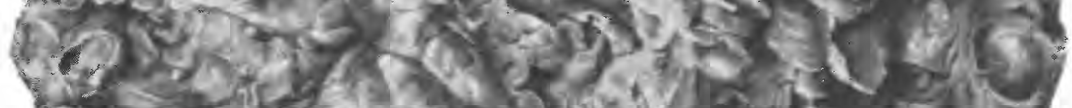

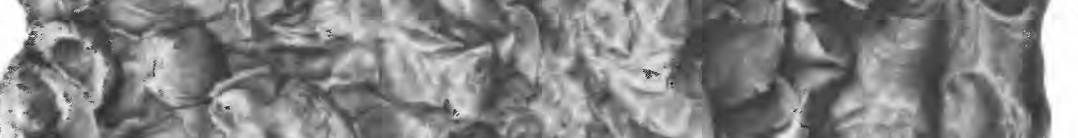

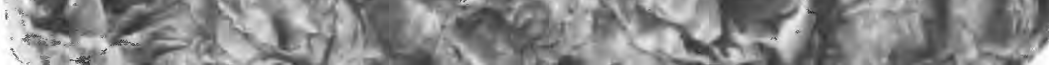

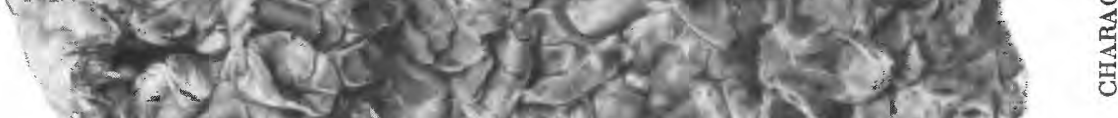

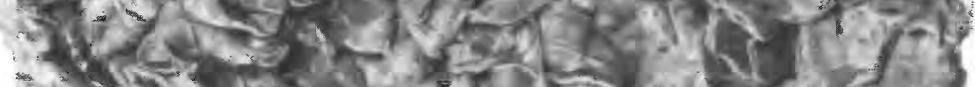

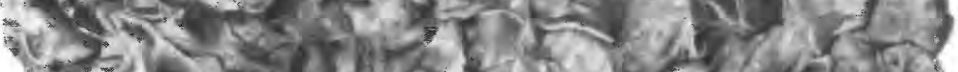

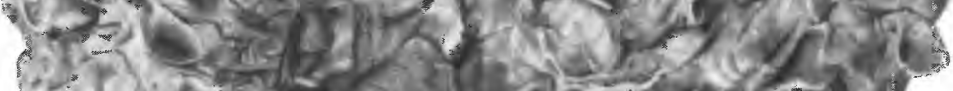

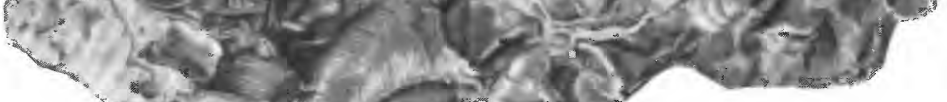

$\dot{p}$

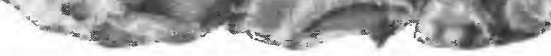



amount, as illustrated by the well at the Bowman ranch, 6 miles north of Sturgis. At this place the water had somewhat greater head than that in the Lakota sandstone and therefore gave a flow, though one of small volume: At Fort Meade and Chambers ranch it did not flow. Possibly at some places these sandstones will yield more satigfactory results.

The Unkpapa sandstone, between the Sundance shale and Morrison formation in the eastern and southeastern part of the Black Hills, may prove to be water bearing, but apparently it is too fine grained or compact to carry a great volume of water. The great mass of gypsiferous red shale of the Spearfish and Opeche formations is not likely to yield much water, and if a small volume is obtained it will probably be highly mineralized. The absence of water in these formations was demonstrated at the deep borings at Edgemont, Spearfish, near Belle Fourche, and Minnekahta, and also at Fort Meade, a short distance east of Sturgis, where the Opeche red beds were reached and no supply was found below a small flow from the Dakota sandstone. It is possible that the shallower wells near Spearfish draw from sandstones in the red beds, for they are not deep enough to reach the Minnelusa sandstone, but it is more likely that they tap upward seepage from the Minnelusa. The Minnekahta limestone is too dense to earry water, notwithstanding its: cavernous character in some places near the surface.

\section{MIN NELUSA SANDSTONE.}

As shown in the sections the outer slopes of the Black Hills and the adjoirning plains (see Pl. X, p. 26, and fig. 2, p. 29) are underlain by the Minnelusa sandstone, which lies at great depth along the eastern side of the area but rises to the surface in the region of the limestone foothills. In its outcrops this formation appears to consist mostly of very porous sandstone, likely to imbibe much surface water and to constitute a water-bearing stratum available for deep wells. The numerous springs which emerge in places from the upper sandstone furnish a further indication of its properties in this regard. In wells at Cambria on the west side and at Edgemont and Minnekahta on the sonth side of the Black Hills the sandstone is very fine textured and the sand grains are so closely cemented by lime that the interstices are filled up, leaving little room for water. In the northern part of the Black Hills region, however, the sandstone is much coarser grained and appears to be less calcareous, especially the upper member of massive white to buff sandstone (see Pl. II, $B$, p. 10), which supplies flowing wells near Rapid City and Spearfish and would probably yield flowing water in most other portions of the

$45726^{\circ}-18-$ wSP $428-3$ 
region on the north and east sides of the Black Hills. As shown on the map (Pl. I, in pocket) this upper sandstone lies at moderate depth in the Red Valley, but to the east its depth gradually increases to several thousand feet near Cheyenne and Belle Fourche rivers.

In the boring at Fort Meade the red beds of the Spearfish formation are about 695 feet thick, and as the Minnekahta limestone and Opeche red beds are only about 130 feet thick the maximum depth to the top of the Minnelusa sandstone is only about 800 to 1,000 feet along the outer margin of the Red Valley and much less as the slopes of Minnekahta limestone are approached. Possibly in places it would be necessary to sink 300 to 400 feet through the Minnelusa beds to reach the water in the lower sandstone, but the prospects are fairly good that a sufficient supply will be found in the upper sandstone, as at Rapid City and Spearfish. As the formation outcrops high on the slopes of the ridges west and southwest of the Red Valley the Minnelusa water may be expected to show considerable head when tapped by wells on the lower lands.

PAHASAPA AND UNDERLYING LIMESTONES.

The Pahasapa limestone, which underlies the Minnelusa sandstone, appears to be too dense to yield water except possibly along some higher slopes where caverns may be penetrated. The same conditions prevail in the thin Englewood and Whitewood limestones which underlie the slopes of the northern hills.

DEADWOOD FORMATION.

The upper and lower sandstones of the Deadwood formation contain water and are the sources of springs along their outcrop or its vicinity. Doubtless these sandstones also contain water throughout their underground extension and could be reached by wells of moderate depth in portions of the area, but unfortunately, as shown in the cross sections (Pl. X, p. 26, and fig. 2, p. 29), they are very deep on the outer slopes of the Black Hills and in the adjoining valleys. The two deep borings at Edgemont and the one at Cambria are believed to draw from this source, and in other parts of the region where the Dakota, Lakota, and Minnelusa waters are unsatisfactory it will be desirable to sink to the Deadwood sandstone. The depth to this sandstone is indicated on the map (PI. I, in pocket) and also in the sections ( $\mathrm{Pl} . \mathbf{X}$ and fig. 2). Its relations to overlying rocks are shown in the sections and also in figure 1 (p. 27). It will be seen that in the Red Valley the depth ranges from 900 to 2,000 feet; along the Dakota-Graneros contact, or outer edge of the hogback ridge, it is about 2,300 feet; at Edgemont it is 2,516 feet; and it gradually increases as the distance from the Black Hills increases, prob- 
ably to 4,200 feet near longitude $103^{\circ} \mathrm{W}$. How far east the sandstone extends is not known. (See fig. 2, p. 29.) The area in which flows may be expected from the Deadwood sandstone is probably great, for the altitude of intake is mostly above 5,000 feet, or higher than all of the lands east of the limestone ridges. The pressure at Edgemont of 75 pounds to the square inch is sufficient to raise the water 240 feet above the mouth of the well, or to an altitude of 3,690 feet. This is high enough to afford a flow in most portions of the Red Valley, especially as the rate probably increases somewhat toward the elevated outcrop or intake zone.

\section{BORINGS AND ARTESIAN PROSPECTS.}

BELLE FOURCHE REGION.

General features.-There are many artesian wells in the Belle Fourche and tributary valleys at and near Belle Fourche. They draw from the Dakota and Lakota sandstones and range in depth from 240 to 2,019 feet, the depths increasing gradually with distance from the foot of the Black Hills. Generally there are two or more flows, the uppermost from the Dakota sandstone, small in volume but relatively soft, and the second and lower flows, much greater in volume and harder in quality, from the Lakota sandstone 100 feet or more below. The head is sufficient to afford flows in a wide area of the lower lands, but a few borings on higher slopes have failed to obtain flows.

Artesian wells and deep borings in the Belle Fourche region.

\begin{tabular}{|c|c|c|c|c|c|}
\hline & Depth. & $\begin{array}{l}\text { Depth } \\
\text { to main } \\
\text { water- } \\
\text { bearing } \\
\text { bed. }\end{array}$ & $\begin{array}{l}\text { Diame- } \\
\text { ter. }\end{array}$ & $\begin{array}{c}\text { Reported } \\
\text { natural } \\
\text { flow. }\end{array}$ & $\begin{array}{l}\text { Pres- } \\
\text { sure. }\end{array}$ \\
\hline $\begin{array}{l}\text { Belle Fourche city wells: } \\
\text { No. } 1 \ldots \ldots \ldots \\
\text { No. } 2 \ldots \ldots \\
\text { No. } 3 \ldots \ldots\end{array}$ & $\begin{array}{r}\text { Feet. } \\
550 \\
525 \\
881\end{array}$ & $\begin{array}{l}\text { Feet. } \\
525 \\
560\end{array}$ & $\begin{array}{l}\text { Inches. } \\
\cdots \\
\ldots\end{array}$ & $\left|\begin{array}{r}\text { Gallons } \\
\text { per min. } \\
2000 \\
30\end{array}\right|$ & $\begin{array}{c}\text { Pounds } \\
\text { per sq.in. } \\
55 \\
45 \\
4\end{array}$ \\
\hline $\begin{array}{l}\text { Belle Fourche, many small w } \\
\text { Belle Fourche, Craft's additio }\end{array}$ & & $\begin{array}{c}(a) \\
b 560\end{array}$ & $1-2$ & $\begin{array}{r}1 \\
45\end{array}$ & \\
\hline Land \& Cattle Co., NW. $\frac{1}{4}$ sec. 11, T. 8 N., R. 2 & 635 & $c 635$ & & Many. & 55 \\
\hline 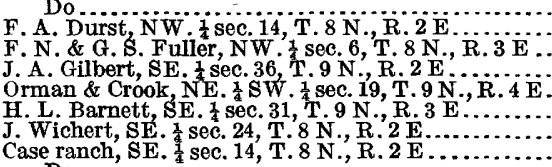 & $\begin{array}{r}745 \\
550 \\
835 \\
836 \\
1,417 \\
935 \\
381 \\
241\end{array}$ & $\begin{array}{c}d 680 \\
500 \\
a 800 \\
e 836 \\
f 1,325 \\
(a) \\
a 360+ \\
(a)\end{array}$ & $\begin{array}{r}4 \frac{1}{2} \\
2 \\
2 \\
3-2 \\
2\end{array}$ & $\begin{array}{r}15 \\
100 \\
30 \\
15 \\
50 \\
5 \\
2 \\
2\end{array}$ & 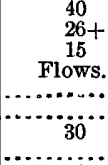 \\
\hline 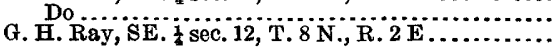 & $\begin{array}{l}355 \\
818\end{array}$ & $(g)$ & $\frac{4}{2}$ & $\begin{array}{r}40 \\
5\end{array}$ & 20 \\
\hline
\end{tabular}

$a$ First flow; soft water.

$b$ Second flow; small flow at 340 feet.

$c$ Second flow; hard water; first flow at 450 feet. In valley.

$d$ Second flow; water also at 450 and 650 feet.

e Soft water; some water at 600 feet.

$f$ Flow also at 1,345 feet.

$g$ Soft water.

$h$ Hard water; water also at 500 feet. 
Artesian wells and deep borings in the Belle Fourche region-Continued.

\begin{tabular}{|c|c|c|c|c|c|}
\hline & Depth. & $\begin{array}{c}\text { Depth } \\
\text { to main } \\
\text { waterr } \\
\text { bearing } \\
\text { bed. }\end{array}$ & $\begin{array}{c}\text { Diame- } \\
\text { ter. }\end{array}$ & $\begin{array}{c}\text { Reported } \\
\text { naturel } \\
\text { flow. }\end{array}$ & $\begin{array}{l}\text { Pres- } \\
\text { sura. }\end{array}$ \\
\hline 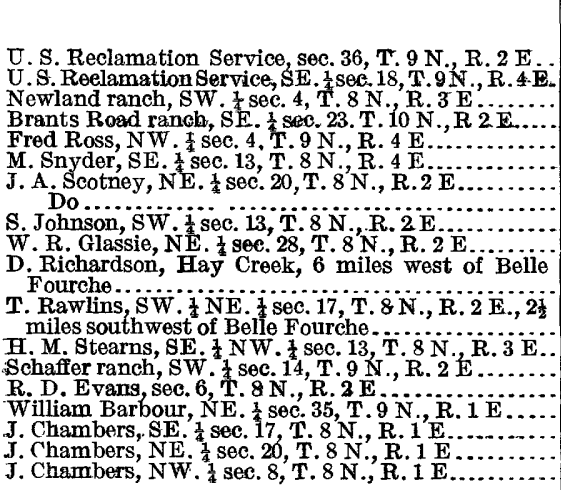 & $\begin{array}{c}\text { Feet. } \\
627 \\
1,388 \\
1,033 \\
2,019 \\
1,858 \\
1,096 \frac{1}{2} \\
330 \\
225 \\
330 \\
320 \\
\\
220 \\
\\
535 \\
600 \\
f 900 \\
900 \\
350 \pm \\
280 \\
i 356 \\
700\end{array}$ & 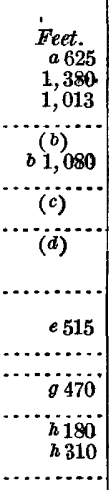 & $\begin{array}{c}\text { Inches. } \\
2 \\
2 \\
2 \\
2 \\
11 \frac{1}{4} \\
2 \\
4 \\
6\end{array}$ & \begin{tabular}{|c|} 
Gallons \\
per min. \\
20 \\
1 \\
15 \\
$3 \frac{1}{2}$ \\
69 \\
25 \\
15 \\
\hdashline$\ldots \ldots$
\end{tabular} & \begin{tabular}{c} 
Pounds \\
per sq.in. \\
$\cdots$ \\
$\mathbf{9 +}$ \\
15 \\
Flows. \\
Elows. \\
30 \\
\hdashline$\ldots$ \\
15 \\
5
\end{tabular} \\
\hline
\end{tabular}

a First flow at 567 feet.

$b$ First flow; soft water.

$c$ Hard water.

d Socond flow.

$e$ First flow at 330 feet.

$f$ In prograss, in shale.

$g$ Soft water; water also at 274 feet.

hu Hard water within 9 feet of surface; ahandoned.

$i$ Water within 100 feet of surface; into red beds 120 feet; abandoned.

Belle Fourche and vicinity.-Since 1904 Belle Fourche has been supplied by water from artesian wells which penetrate the Dakota or underlying Lakota sandstone. The water in the deeper wells has sufficient pressure to flow into a tank 75 feet above the ground on. a knoll just south of the railroad depot. Shallower. wells afford supplies at a number of residences. The first well had a depth of $525 \frac{1}{2}$ feet and flowed 60 gallons a minute, and originally the pressure was considerably more than 55 pounds to the square inch. The well finally got out of order, apparently owing to a break in the casing, and other wells were sunk, which obtained additional supplies. The materials penetrated in the first well were as follows:

Record of first well at Belle Fourche.

Feet.

Q-207

Shale - 207-307.

Sandstone (Dakota), yielding a small flow at 245 feet

Soft clay (Fuson), containing a thin layer of sand yielding

a small second flow:-

$307-425$

Sandstone (Lakota) $425-525 \frac{1}{2}$

- The Lakota sandstone contained water at several horizons, the volume and head gradually increasing with depth, and the maximum flow being at a depth of about 510 feet, in the lower part of the formation. 
The second well, on somewhat lower land near the center of the village, had the following record:

Record of second well at Belle Fourche.

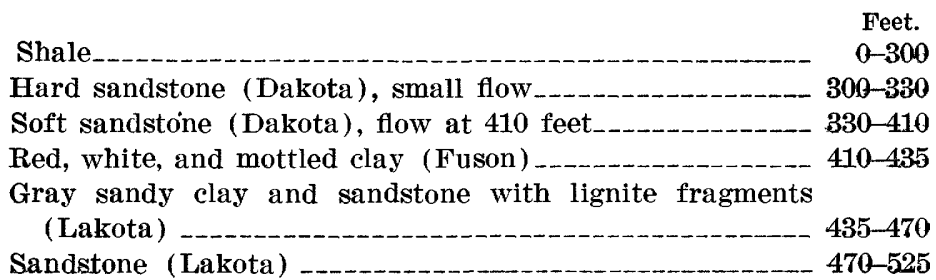

A pressure of 45 pounds was reported in this well.

A third well, bored in 1903 to a depth of 881 feet, found waterbearing strata at intervals from 297 to 560 feet. This well is 4 inches in diameter and has a flow of 30 gallons a minute. Several small wells in the village are supplied by the first flow at depths of 300 to 400 feet.

A well in Craft's addition, three-fourths of a mile east-southeast of well No. 1, obtains water with a pressure of 55 pounds from the second flow at a depth of 560 feet. This well was drilled to 897 feet, with no increase of flow below 560 feet.

There are two artesian wells on property of the Belle Fourche Land \& Cattle Co. in the NW. $\frac{1}{4}$ sec. 11, T. 8 N., R. 2 E., a mile north of Belle Fourche. The first, which was sunk in 1904, has a depth of 650 feet. It draw from the second flow at 635 feet. The water is somewhat hard and the pressure is 55 pounds. A flow of softer water was found at a depth of 450 feet, which is the first flow. The following recard is given:

Record of artesian well 1 mile north of Belle Fourche.

Shale _- $\begin{array}{r}\text { Feet. } \\ 0-350\end{array}$
Sandstone (Dakota)
Shale and clay (Fuson)
Sandstone (Lakota)

A second well on a small knoll north of the river in the northwest quarter of the same quarter section has a depth of 744 feet. It yields a 15-gallon flow of soft water under a pressure of 40 pounds. A small flow was found at a depth of 650 feet in this well.

F. Durst has a well in the NE. $\frac{1}{4}$ NW. $\frac{1}{4}$ sec. 14, T. 8 N., R. 2 E., on a hill about 70 feet above Belle Fourche. It was sunk in 1906 and has a diameter of $4 \frac{1}{2}$ inches and a depth of 550 feet. The main flow was reached at 500 feet and minor flows at 350 and 400 feet. The pressure is sufficient to raise the water 60 feet above the surface, 
with a volume of 100 gallons a minute. The water is fairly soft. The following record is supplied by the driller:

Record of Durst artesian well, south of Belle Fourche.

Sand and gravel
Black shale
Gray shale
Sandstone
Shale
Clay and shale
$20-220$

Two wells on the Case ranch, a mile farther south, have depths of 241 and 355 feet and yield good flows of soft water. The deeper well shows a pressure of 26 pounds.

Another shallow well just south of Minnesela, 381 feet deep, has a 2-gallon flow of soft water under a pressure of 30 pounds.

The Gilbert, Barrett, and Fuller wells, on the south side of Belle Fourche River 2 to 3 miles below Belle Fourche, range from 835 to 935 feet in depth. They have large flows of soft water from the Dakota sandstone or "first flow." The well on the Newland ranch in the SW. $\frac{1}{4}$ sec. 4 , T. 8 N., R. 3 E., with a depth of 1,033 feet, reaches this flow at 1,013 feet. This well is in the deeper part of the syncline that crosses Belle Fourche River 5 miles below Belle Fourche and had to penetrate nearly the entire thickness of Graneros shale.

Belle Fourche project.-The United States Reclamation Service drilled two artesian wells in connection with the Belle Fourche project-one at the dam site on Owl Creek, in the SE. $\frac{1}{4} \mathrm{SE} . \frac{1}{4}$ sec. 18, T. 9 N., R. 4 E., the other at the intake of the diversion canal $1 \frac{1}{2}$ miles below Belle Fourche.

The well at the dam site is 1,386 feet deep and 2 inches in bore and has a 1-gallon flow under pressure sufficient to raise the water 20 , feet or more above the surface. The boring was in Carlile and Graneros shales, with hard streaks at $250,540,640,790,900$, and 1,300 feet, the one at 250 feet probably representing a portion of the Greenhorn limestone. The Dakota sandstone was entered near the bottom, so the well is supplied by the first flow. A partial analysis of the water from this well shows that it contains about 700 parts per million of total solids, about 60 parts per million of sodium, a smaller amount of calcium and magnesium, and no sulphate.

The well at the intake of the diversion canal is on the north bank of Belle Fourche River, in the SW. $\frac{1}{4}$ sec. 36, T. 9 N., R. 2 E. It is 627 feet deep and 2 inches in diameter, and obtains its supply from a depth of 625 feet. A first flow was found in the Dakota sandstone at 
a depth of 567 feet; shale (Fuson) separates the two flows. The following analysis of the water was made by F. M. Eaton:

Analysis of water of Reclamation Service artesian well at intake $1 \frac{1}{2}$ miles below Belle Fourche.

Parts per
million.

Hay Creek valley.-There are deep wells at intervals up Hay Creek valley, most of which yield flows. At the Scotney ranch, in the northeast corner of sec. 20, T. 8 N., R. 2 E., there are two artesian wells, one 225 feet deep which flows 15 gallons, and another on slightly higher ground 330 feet deep which has a 28-gallon flow under a pressure of 30 pounds. The water is hard. At the Rawlins ranch, in the NE. $\frac{1}{4}$ sec. 16 of the same township, a boring 535 feet deep yields a 5-gallon flow and had a small first flow at 330 feet. The pressure is 10 pounds or more. At the Richardson place at the crossing 6 miles above Belle Fourche a well 220 feet deep has a 25-gallon flow. It begins in the Fuson formation and reaches water in the basal portion of the Lakota sandstone.

Chambers ranch.-On the Chambers ranch, in the SW. $\frac{1}{4}$ NW. $\frac{1}{4}$ sec. 8 , T. 8 N., R. 1 E., on the hogback ridge 9 miles west of Belle Fourche, a boring was made in 1899 to a depth of 700 feet. It obtained no flow and was finally abandoned. The record is shown in figure 6 (p. 40 ).

The boring began at the top of the Dakota sandstone and penetrated that formation and the underlying liuson and Lakota formations within the first 200 feet. The water at a depth of 180 feet was in the Lakota sandstone, which affords the large flows in the valleys about Belle Fourche, but the boring was on land more than 100 feet too high for a flow. The reddish sandstone at 490 to 540 feet was in the Sundance formation, and the water at 540 feet was in the sandstone near the lower portion of that formation. The Spearfish red beds were entered at a depth of 580 feet and penetrated 120 feet. It is unfortunate that this hole was not deep enough to reach the Minnelusa sandstone.

Two borings 280 and 356 feet deep were sunk on the north side of Hay Creek in the southeast corner of sec. 17 and the NE. $\frac{1}{4}$ sec. 20 , T. 8 N., R. 1 E. They penetrated Sundance beds and found some water rising within 9 feet of the surface. Both wells were abandoned. 
Orman.-The Orman well is in the NE. $\frac{1}{4}$ SW. $\frac{1}{4}$ sec. 19, T. 9 N. R. 4 E., at the south end of the Owl Creek dam. It was finished in October, 1906. The diameter of the well is 3 inches and its depth is 1,417 feet. The water-bearing bed was entered at a depth of 1,325 feet and is a very coarse sandstone 40 feet thick. The flow at an altitude of 3,017 feet, or 18 feet above the ground, is 50 gallons a minute; 26 feet higher it is 32 gallons. The temperature of the water is $94^{\circ}$. Another well 6 inches in diameter was drilled on ground

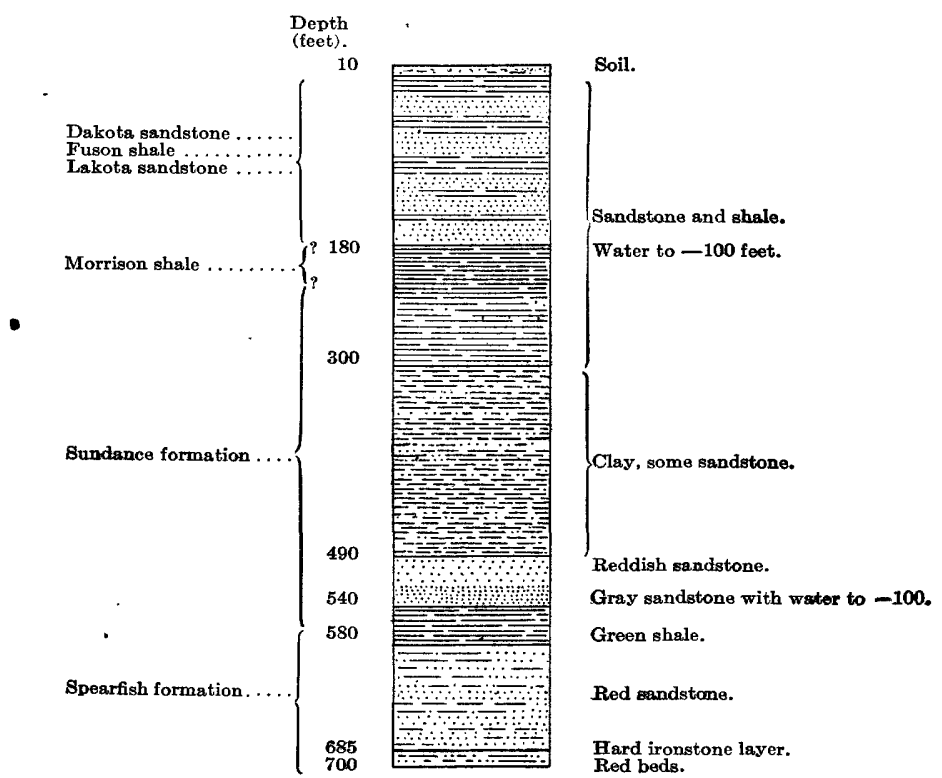

Figurw 6. - Section of boring at Chambers ranch, 9 miles west of Belle Fourche, s. Dak. 45 feet higher a few rods farther south. An analysis of the water from the 3-inch well by W. A. Converse is as follows:

Analysis of water from 3-inch well at Orman.

\begin{tabular}{|c|c|}
\hline \multirow{2}{*}{ Silica $\left(\mathrm{SiO}_{2}\right)$} & $\begin{array}{l}\text { Parts per } \\
\text { million. }\end{array}$ \\
\hline & 1.3 \\
\hline Oxides of iron and aluminum $\left(\mathrm{Fe}_{2} \mathrm{O}_{3}+\mathrm{Al}_{2} \mathrm{O}_{3}\right)$ & 2. 7 \\
\hline alcium (Ca) & 183 \\
\hline Magnesium $(\mathbf{M g})$ & 57 \\
\hline Sodium and potassium $(\mathrm{Na}+\mathrm{K}) \ldots$ & 86 \\
\hline Bicarbonate radicle $\left(\mathrm{HCO}_{3}\right)_{-}$ & 248 \\
\hline Sulphate radicle $\left(\mathrm{SO}_{4}\right)_{\ldots} \ldots$ & 640 \\
\hline Chloride radicle $(\mathrm{Cl})_{-\ldots}$ & 3.5 \\
\hline Nitrate radicle $\left(\mathrm{NO}_{3}\right)$ & .00 \\
\hline rganic and volatile matter & .5 \\
\hline
\end{tabular}

Snoma.-A well on the Stearns ranch, a mile northwest of Snoma, near Fruitdale post office, is 600 feet deep and yields a flow reported to be 450 gallons a minute under a pressure of 125 pounds. 
Area of flow.-The map (Pl. I, in pocket) shows the area in which flowing wells may be expected. The representation is based on the pressures reported in a number of wells and on the theoretical head which should be expected from the altitude of the outcrops of the water-berring sandstone in the hogback ridge. Owing to the small amount of evidence available the boundaries of the area are only approximately known, and it should be borne in mind that they differ somewhat for the different flows. Ordinarily the water from the basal beds of Lakota sandstone has the greatest pressure, so that it will flow at higher altitudes than the water from the Dakota sandstone, or "first flow." The pressures in the wells in Belle Fourche indicate that the head of the water is sufficient to raise it to an altitude of about 3,150 feet, and the pressure in wełls on higher lands to the south indicate a somewhat higher head, although these wells have less surface pressure. The head. indicated by the reported pressure . in the Stearns well near Snoma is 3,220 feet. The head diminishes toward the east, and in the valley of Indian Creek it is less than 3,000 feet. The well at the Ross ranch, however, indicates that the head would afford a flow at altitudes of somewhat more than 2,885 feet. The flow at Brant's road ranch, in the Owl Creek valley north of Belle Fourche, indicates that in that vicinity the water would rise to an altitude of more than 3,060 feet. Unfortunately the pressure of this well was not ascertained, so that the maximum altitude of head can not be calculated. The flowing well 2 miles south of St. Onge adds confirmatory evidence to the belief that flows may be obtained up to the base of the hogback ridge. Doubtless also the flow area will be found to extend up some of the valleys part way across the hogback ridge, to the line along which the base of the Lakota sandstone pasees underground.

It is probable that artesian flows may be obtained from the upper part of the Mimnelusa sandstone in the Red Valley area and adjoining slopes. (See p. 24.)

\section{ST. ONGE AND WHITEWOQP REGION.}

At St. Onge a 617-foot well yields a good supply of water from the Lakota sandstone. The diameter of this well is 2 inches, the flow 125 gallons a minute, and the pressure is stated to be 20 pounds to the square inch. Another well of the same size, three-fourths mile east of St. Onge, is 653 feet deep and has a 150-gallon flow. The same artesian conditions extend up the shale valley southeastward for 6 to 8 miles and the beds gradually come nearer the surface. A 175-foot well on False Bottom Creek, 2 miles due south of St. Onge, yields an excellent flow from the Lakota sandstone. White- 
wood is in the Red Valley.near the line of contact of the red shales and the overlying Sundance formation. It is probable that the Minnelusa sandstone would yield a flow at this place, for the conditions are closely similar to those at Spearfish and Rapid City, where good flows are obtained. The depth to the top of the Minnelusa sandstone is greater, however, because 550 to 600 feet of red shale of Spearfish formation have to be penetrated, 35 feet of Minnekahta limestone, and 90 feet of Opeche red beds; probably 700 feet in all. Possibly it would be necessary to sink some distance into the Minnelusa sandstone to obtain a flow. About 1,100 feet deeper is the upper sandstone of the Deadwood and 1,400 feet deeper the basal Deadwood sandstone, both of which offer good prospects for artesian flows.

The same conditions exist in the Red Valley southeastward to Sturgis and also up the narrow valley past Crook into Boulder Park, where there is a shallow basin holding 200 to 300 feet of Spearfish red beds.

VALE AND NEWELL REGION.

The artesian area of the Belle Fourche district extends for several miles down the valley and some distance up the larger branch valleys in the Vale and Newell region. An artesian well was sunk at Vale in 1909 and still furnishes a flow of good water. Its depth is 2,215 feet and it flows somewhat less than 1 gallon a minute. According to one statement shale was penetrated for 2,100 feet, at which depth some sandstone was found. This was underlain by a thin coaly layer, 25 feet of hard gray shale, and about 15 feet of white chalky clay, alternating with blue and red chalky material. At 2,200 feet sandstone was entered and at the bottom the boring was in fine black sand, which yielded the flow. The identity of the first sandstone is not clear; presumably the top of the Dakota sandstone was reached at a depth of 2,200 feet. The good quality of the water and the light flow also indicate a source near the top of this sandstone. Doubtless if the boring had been continued into the Lakota sandstone, 150 feet or more below, a large volume of water would have been obtained and under greater head. It might, however, contain more mineral matter, like the water in most wells in the Belle Fourche region and at Fruitdale. It is reported that the well is cased with $4 \frac{1}{2}$-inch casing at the top, 900 feet of 3 -inch casing, and $1 \frac{1}{4}$-inch casing at the bottom. The pressure is stated to be 22 pounds to the square inch, sufficient to lift the water 50 feet above the surface in a pipe, or to 2,824 feet above sea level.

The area in which flowing wells may be expected in the ValeNewell area and southeastward is shown on the map (P1. I, in pocket), as indicated by the pressures reported in wells in regions 
to the west and southwest and by the slope of the head toward wells in the central part of the State. Owing to the great distance between these sources of data the head can only be approximated and the boundaries of the area in which flowing wells may be obtained can be only approximately delineated. Those indicated are based on the probable head of water from the basal beds of Lakota sandstone, which has considerably greater pressure, and accordingly affords flows at higher altitudes than the water from the Dakota sandstone, or "first flow." The low pressure in the artesian well at Vale is believed to be that of the first flow, and the pressure of lower flows at that place doubtless will be found to be considerably greater, probably representing a head of more than 2,900 feet, as shown on the map. The head undoubtedly diminishes toward the east and northeast; at the mouth of Willow and Horse creeks it is probably less than 2,850 feet and may be only 2,800 feet, but this is sufficient to afford flows in all the lower lands. Flowing wells are to be expected from the second flow some distance up the slopes about Newell and in all of the lower lands about.Vale, Empire, Horse Creek, Reed, and Volunteer post offices. It is likely that a flow may be obtained at Newell, altitude 2,850 feet, for the head of the second flow at that place probably will suffice to raise the water to 2,875 feet. Possibly, however, the head will be slightly less than 2,850 feet, in which event the water would come near enough to the surface to be pumped. The depth to the.Dakota sandstone, or first flow, at Newell is about 2,450 feet, and the Lakota sandstone, which carries the second flow, is 150 to 200 feet deeper.

The higher ridges of the divides in the region about Newell and Vale and south and southeast of those places, as indicated on the map (Pl. I, in pocket), are probably too elevated for flows, but the limits of flow areas on these slopes can only be approximated. Apparently the prospects for flow also are fairly good in a wide area in Fourmile and Elk Creek basins, north and northeast of Volunteer.

The Minnelusa sandstone, which probably contains a large volume of water under high pressure, underlies the Vale-Newell region at depths of 3,500 to 4,000 feet, too deep for ordinary well drilling.

\section{STURGIS AND BEAR BUTTE REGION.}

List of wells.-Artesian waters from the Dakota and Lakota sandstones have been developed at places north of Sturgis, and some unsuccessful attempts have been made to test lower water-bearing sandstones. The following is a list of borings within 7 miles of Sturgis: 
Deep wells in the sturgis region.

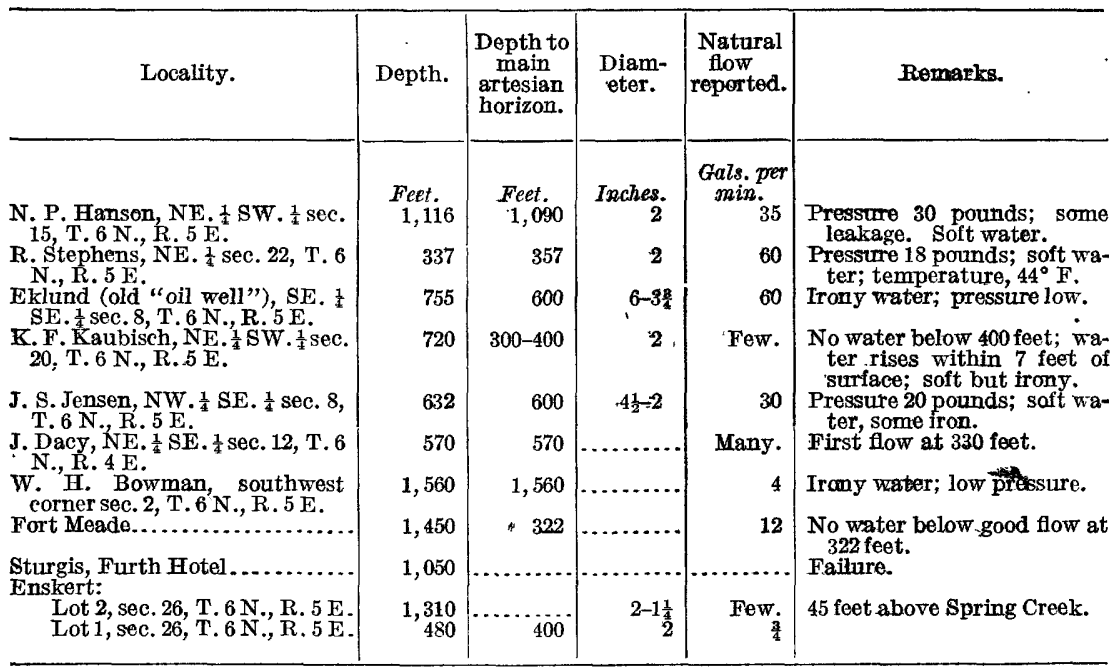

Sturgis.-The principal wells which tap the Lakota and Dakota sandstones are in the region north and northwest of Sturgis not far east of the foot of the hogback ridge. Here the Dakota sandstone lies less than 1,000 feet deep under a region of considerable extent, but the easterly dip carries it deeper to the east. The Lakota sandstone, which contains the principal water supplies, lies 100 to 200 feet deeper. The large igneous mass of Bear Butte locally interrupts the continuity of the water-bearing sandstones. These sandstones have been penetrated by several wells, most of which yield large flows of excellent water. One well sunk for oil at the Eklund ranch, 6 miles northwest of Sturgis, in the southeastern part of sec. 8 , T. 6 N., R. 5 E., is 755 feet deep, but obtains its principal water supply at a depth of 600 feet in a bed of soft sandstone (Lakota) 85 feet thick. The flow is estimated at 60 gallons a minute, and the pressure was reported to be 20 pounds to the square inch, but a test in 1910 showed a very low figure, 5 pounds or less. A small flow was also found in the Dakota sandstone at a depth of 440 feet. The following record is given:

Record of artesian well 6 miles north by west of Sturgis, S. Dak.

Feet.

Dark shale (Graneros)

Shale and sandstone, small flow at 440 feet (Graneros and

Dakota) $275-445$

Red clay (Fuson) $445-505$

"Rocks" (probably Lakota sandstone in part) $505-585$

Soft sandstone, with main flow at 600 feet $585-670$

Coal, 1 inch at

Dry sand $670-685$

Black shale, with 2 inches of coal (basal Lakota) 685-705

Green shale, with thin limestone layers (Morrison) $705-755$ 
The Lakota sandstone appears to begin at 505, feet in this boring and to continue to the top of the Morrison shale at 705 foet, including the coaly shale at base, as in the Aladdin and Cambria areas. The Jansen. well, about one-third of a mile northwest, has a 39 -gallon flow from the same depth, 600 feet, and is used for irrigating several acres of orchard and garden. It is reported to have passed through 40 feet of surface material, 250 feet of shale, 10 feet of sandstone, 240 feet of hard shale, and 92 feet of sandstone- $a$ total of 632 feet.

Another deep well (on the Kaubisch ranch), in sec. 20 of the sandstone passes beneath the Graneros shale, is 720 feet deep, but obtains its main supply from beds between 300 and 400 feet. The water rises within 7 feet of the surface, but by digging a trench it has been made to flow to the adjoining lower ground in small volume. The water is soft but contains considerable iron. The first sandstone at a depth of about 200 feet yielded water which overflowed, and the next sandstone at 400 feet yielded additional volume. At the bottom the boring was in Sundance beds containing Belemnites. The Dacey well, 2 miles west of the Eklund well, is 570 feet deep and obtained two flows, the first at 330 feet and the second at the bottom of the boring. The volume is large and the pressure 15 pounds to the square inch.

The Bowman well, in the southwest corner of sec. 2 , T. 6 N., R. 5 E., was sunk in 1907 to a depth of 1,560 feet and flows 4 gallons a minute with low pressure. Very little information is available as to the record or other features of this well. Samples from 1,000 to 1,200 feet were all light-gray clay, apparently from the Sundance formation. Doubtless the Dakota sandstone was entered at a depth of about 700 feet and the Lakota sandstone at 850 feet, but presumably the water which they contained did not have sufficient head to afford a flow on the high table-land on which the well is situated. Probably the flow is from the basal sandstone of the Sundance formation. This well apparently shows that the altitude of head of the DakotaLakota water in this area is somewhat less than 3,200 feet, the height of the land on which the well is sunk. However, flowing wells may be expected throughout the lower lands to the north.

In the Hansen well, 5 miles due north of Sturgis, a depth of 1,116 feet was atained. Sandstone began at 700 feet, but no flow was obtained until the boring reached a depth of 1,090 feet, doubtless in the lower part of the Lakota sandstone. The pressure at the mouth of the well was reported to be 30 pounds, indicating a head of 69 feet, equivalent to an altitude of 3,220 feet, or somewhat higher than the altitude of outcrops of Dakota sandstone a mile to the east.

The Stephens well, a mile southeast of the Hansen well, or 4 miles north-northeast of Sturgis, is 377 feet deep. The first 250 feet consists of blue shale (Graneros), which is underlain by 25 feet of sand- 
stone (Dakota), followed by 80 feet of gray shale (Fuson) and 22 feet of sandstone (Lakota), containing water. The pressure was 18 pounds on a pipe 10 feet lower than the well, with some slight loss by leakage. The water is said to rise 48 feet at the well, which indi-

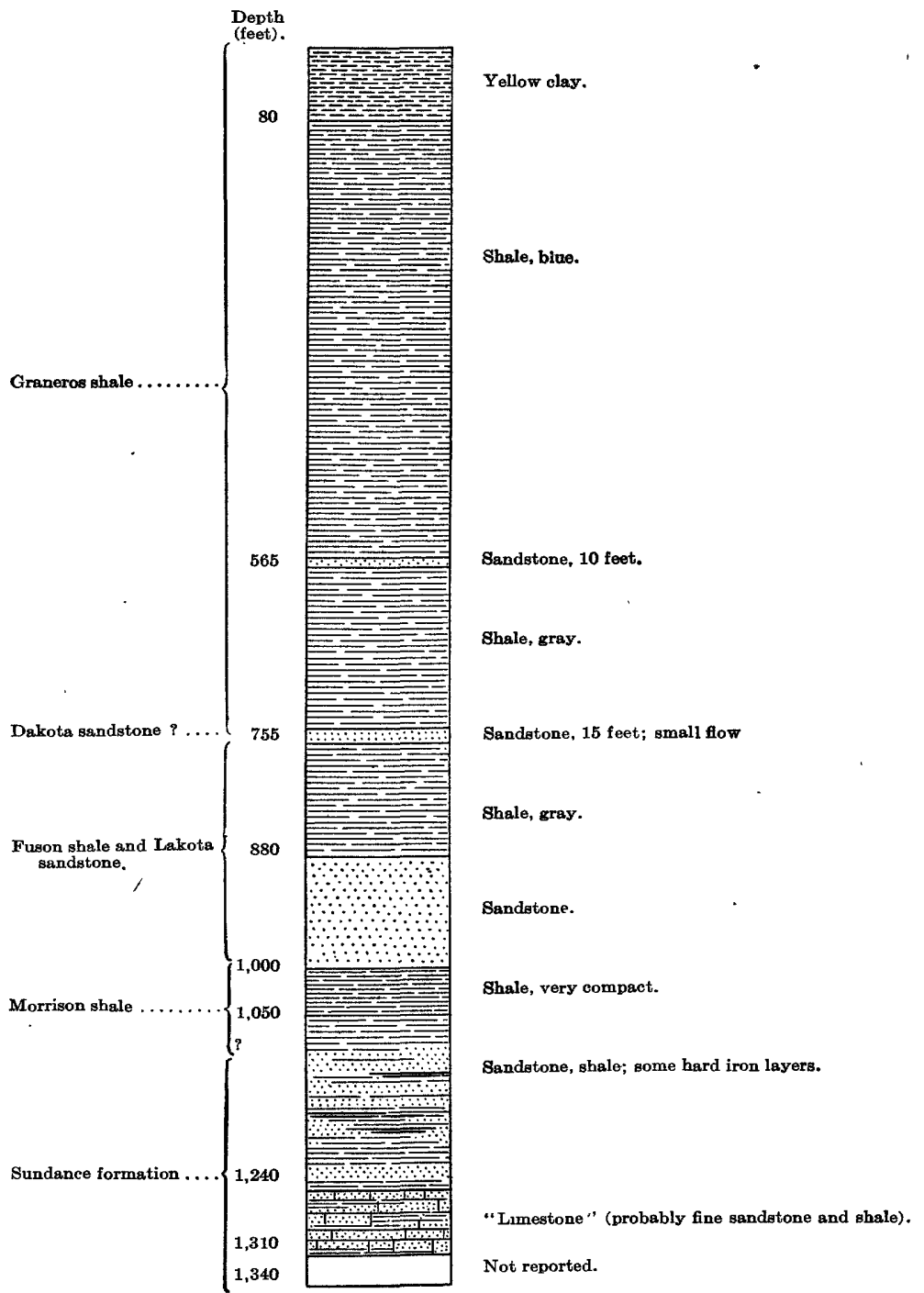

Figure 7.-Section of boring at Enskert ranch, lot 2, sec. 26, T. 6 N., R. 5 E., 3 miles northeast of Sturgis, S. Dak.

cates a pressure of nearly 21 pounds and a head sufficient to rise to an altitude of 3,250 feet.

A 1,340-foot boring on the Enskert ranch, 3 miles northeast of Sturgis, penetrated Dakota and Lakota sandstones and nearly reached the bottom of the Sundance formation, where, on account of its small 
bore ( 2 inches), drilling had to cease. It obtained a 1 to 2 gallon flow of very hard water from sandstone, presumably Dakota, at a depth of 740 to 755 feet. The section shown in figure 7 was supplied by the driller.

A well completed in 1912 on the next lot east is 480 feet deep, a depth beyond which drilling could not proceed on account of caving of soft material. A three-fourths gallon flow of irony water (slightly alkaline) was obtained from 400 to 450 feet. Sandstone (Dakota) was entered at 345 feet. Below 450 feet were found 12 feet of white shale and 20 feet of red shale. As this well is some distance northeast of the deep one in lot 2 , the shales are deeper.

It is difficult to understand why these borings did not have better success, but apparently the Lakota sandstone is choked with fine sediment at this place. If this explanation is correct, it indicates a most unusual condition, which is probably local.

Fort Meade.-Several years ago a well sunk by the Quartermaster's Department, United States Army, at Fort Meade, just east of the ridge of Dakota sandstone, developed a 12-gallon flow of good water at a depth of 322 feet. With the expectation of finding an additional supply it was continued deeper and penetrated the red shale of the Spearfish formation to the Minnekahta limestone, where, unfortunately, it was discontinued without testing the prospects for obtaining water in the Minnelusa sandstone 100 feet or more below. The record, based mainly on samples furnished by the quartermaster, is given in figure 8 .

The boring at the Furth Hotel in Sturgis is reported to have reached a depth of 1,050 feet, where the tools stuck and work was abandoned without obtaining any water. As the boring began some distance below the top of the Spearfish formation, it should have passed through nearly all, if not all, of the Minnelusa sandstone at the depth reported and obtained a flow of water. It is stated that at about 200 feet a crevice was entered and "nothing came out of the hole" below that depth. This statement probably indicates some misunderstanding as to the depth, for the existence of such a crevice is impossible, and progress from 200 to 1,050 feet could not have been made without producing borings. It is therefore believed that the Minnelusa sandstone was not penetrated and the boring did not test the water conditions.

The wells in T. 6 N., R. 6 E., a few miles north of Sturgis, show that flowing water may be expected from the Dakota and Lakota sandstones, especially the Lakota, in a wide area of the valley lands north and east of Sturgis. Bear Butte causes a local interruption in the regular uniform dip to the eastward and deflects the "head" lines somewhat, but the general relations in most of the area are 
those shown in section 3 on Plate $X$ (p. 26).. In the valley of Bear Butte Creek, for example, the top of the Dakota sandstone reaches a depth of about 1,500 feet due south of the end of Bear Butte

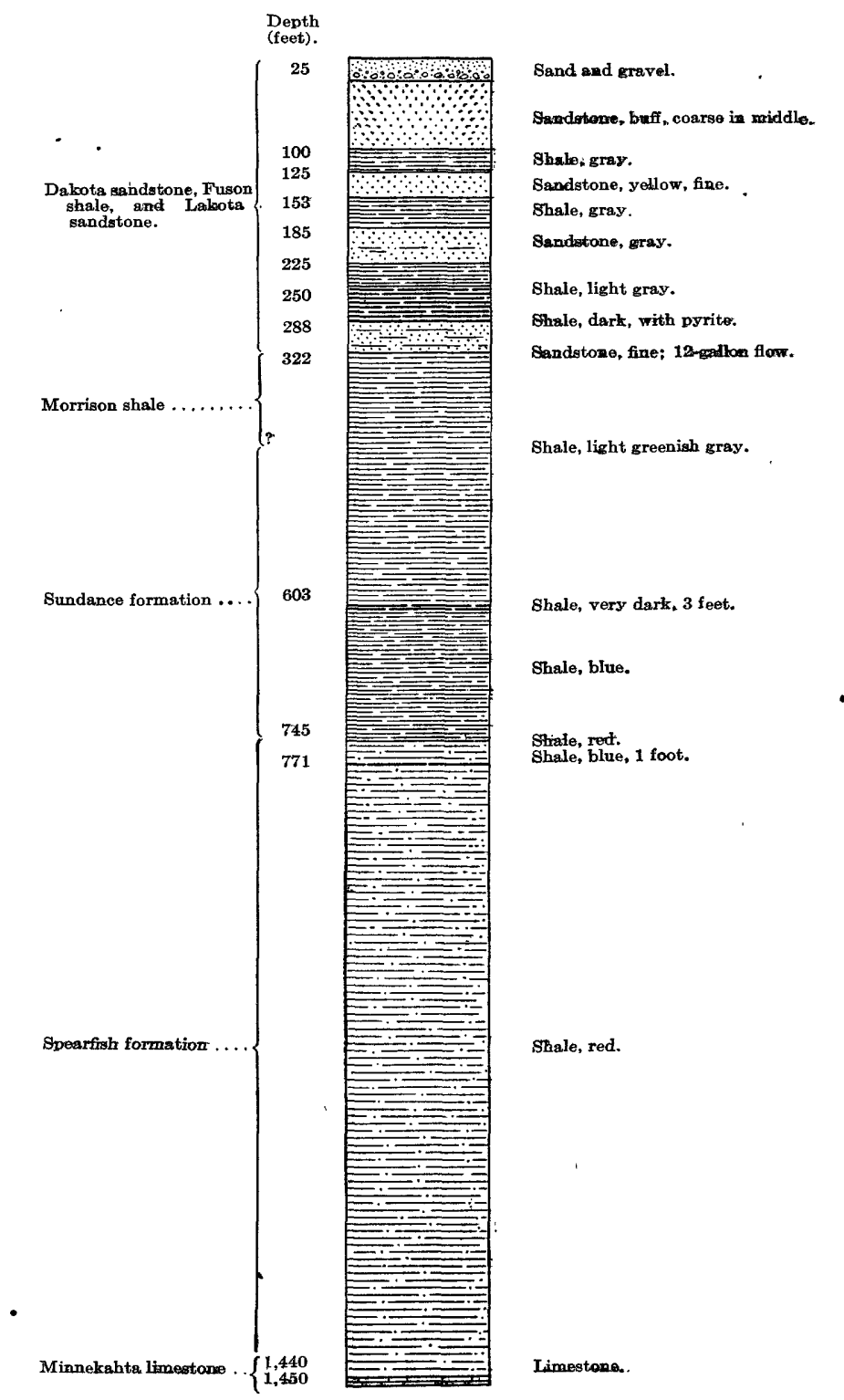

FIGURe 8.--Section of boring at Fort Meacte, east of Sturgis, S. Dak.

and of 2,000 feet in the east line of R. $6^{\circ} \mathrm{E}$. The flow area from Fort Meade eastward for a few miles is restricted to the bottom and lower slopes of the valley. In R. $7 \mathrm{E}$. the eastward dip of the beds 
diminishes in rate and probably the flow area widens greatly, especially over the low table-land south of the Bear Butte Valley. At Volunteer the Dakota sandstone is about 2,400 feet below the surface, and at Alkali and Hereford about 2,700 feet. In this region the area of flow is a wide belt adjoining the Belle Fourche Valley. (See PI. I, in pocket.) ' Its limits, however, are not very accurately determined, for the probable head of the artesian water can only be approximated.

Notwithstanding the failure of the boring at the Furth Hotel in Sturgis, it is believed that the Minnelusa sandstone will yield artesian water in the Sturgis region and far up and down the Red Valley north and south, but possibly it will be necessary to sink to its lower part. The depths are indicated on the map and also in section 3 in Plate X (p. 26). About 1,100 feet deeper is the top sandstone of the Deadwood, and about 1,400 feet deeper is the basal sandstone, in which there are excellent prospects for artesian flows.

\section{SPEARFISH REGION.}

A few borings in and near Spearfish have demonstrated the waterbearing capabilities of the Minnelusa sandstone on the northern slope of the Black Hills. They indicate that flows may be expected from this source at moderate depth in a wide area of the Red Valley extending north to Redwater Creek and eastward down the Centennial Prairie. The area over which the depth is less than 500 feet is shown on the map (Pl. I, in pocket).

Wells in vicinity of Spearfish, S. Dak.

\begin{tabular}{|c|c|c|c|c|c|}
\hline $\begin{array}{l}\text { Location with reference to } \\
\text { Spearfish. }\end{array}$ & Depth. & $\begin{array}{l}\text { Depth to } \\
\text { primcipal } \\
\text { artesian } \\
\text { horizon. }\end{array}$ & $\begin{array}{l}\text { Diam- } \\
\text { eter of } \\
\text { well. }\end{array}$ & $\begin{array}{l}\text { Natural } \\
\text { flow re- } \\
\text { ported. }\end{array}$ & Remarks. \\
\hline 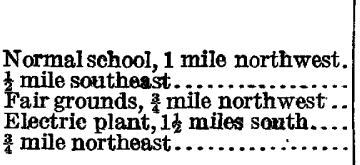 & $\begin{array}{r}\text { Feet. } \\
411 \\
275 \\
300 \\
415 \\
701\end{array}$ & $\begin{array}{r}\text { Feet. } \\
300 \\
215 \\
260 \\
323+398 \\
660\end{array}$ & $\begin{array}{c}\text { Inches. } \\
6 \frac{1}{1} \\
6 \frac{1}{2} \\
5 \\
4\end{array}$ & $\begin{array}{r}\text { Gals. per } \\
\text { min. } \\
160 \\
312 \\
115 \\
50 \\
\text { Few. }\end{array}$ & $\begin{array}{l}\text { Pressure } 20 \text { pounds or more. } \\
\text { Pressure } 31 \text { pounds. } \\
\text { Pressure } 15 \text { pounds. } \\
\text { Flaws. } \\
\text { Some water within } 150 \text { feet }\end{array}$ \\
\hline $\begin{array}{l}2 \frac{1}{2} \text { miles northwest....................... } \\
\text { Sommers ranch, } 3 \frac{1}{3} \text { miles north. }\end{array}$ & $\begin{array}{l}312 \\
\mathbf{3 7 0}\end{array}$ & $\begin{array}{l}305 \\
370\end{array}$ & & $\begin{array}{l}15 \\
15\end{array}$ & $\begin{array}{l}\text { Pressure } 20 \text { pounds. } \\
\text { Elows. }\end{array}$ \\
\hline
\end{tabular}

The water is soft and ample in volume for ranch use. The first well sunk was 415 feet deep at the electrie-light plant in Spearfish Canyon, $1 \frac{1}{2}$ miles south of Spearfish. This well begins near the top of the Minnelusa sandstone and penetrates about 17 feet into the underlying Pahasapa limestone. A 32-gallon flow, found at a depth $45726^{\circ}-18-$ WSP $428-4$ 
of 323 feet in yellow sandstone, increased to 50 gallons as the remaining 75 feet of the lower Minnelusa sandstone was penetrated. The flowing well at the fair grounds, a short distance northwest of Spearfish, is 300 feet deep, but draws its principal supply from a depth of 260 feet, probably from a top member of the Minnelusa sandstone. The pressure is 15 pounds, and the flow is 115 gallons. A similar well at the normal school is 411 feet deep and has a 160-gallon flow from a depth of 300 feet and a pressure of 20 pounds or more. A well in the NE. $\frac{1}{4}$ NW. $\frac{1}{4}$ sec. 4 , T. 6 N., R. 2 E., $2 \frac{1}{2}$ miles northwest of Spearfish, is 312 feet deep, and its flow is under sufficient pressure to rise 45 feet above the surface. The bed that is the principal source of water lies at a depth of 305 feet. The water is medium soft and flows 15 gallons a minute. Red beds are reported to a depth of 203 feet, below which lies 2 feet of limestone, underlain by a foot of water-bearing sanḑ. Probably the water comes up through crevices from Minnelusa sandstone far below, but may possibly come from a sandstone bed in the Sundance formation. The Harriman boring, three-fourths mile east of Spearfish, reached a depth of 701 feet. It began in the upper part of the Spearfish formation and is reported to have penetrated limestone (Minnekahta) from 453 to 483 feet. The characteristic purple clay at the top of the Opeche formation was reported at 483 to 586 feet. The record is somewhat indefinite as to underlying beds; but water which rises within 150 feet of the surface was found at a depth of 660 feet, presumably in the upper part of the Minnelusa sandstone.

A well at the Sommers ranch, $3 \frac{1}{2}$ miles northwest of Spearfish, is 370 feet deep and has a 15-gallon flow. It begins just above the top of the Minnekahta limestone and at a depth of 50 feet passes into Opeche shale. The water is from the lower part of the upper member of the Minnelusa sandstone.

Undoubtedly the head of water in the Minnelusa sandstone is sufficient to give flows throughout the Red Valley, except in the higher slopes and ridges. Apparently in places there is some leakage into overlying beds. Artesian water may also be expected in Deadwood sandstone in two beds, one about 1,100 feet below the top of the Minnelusa sandstone and a lower one 250 feet deeper. The lower bed has the best prospects for water, which would have a head sufficient to afford flows under high pressure in all parts of the Red Valley, except, perhaps, the highest parts of the adjoining slopes or the ridge culminating in Lookout Peak.

RAPID CITY REGION AND EASTWARD.

Three flowing wells in the Red Valley, 2 miles northwest of Rapid City, indicate that water is obtainable from the Minnelusa 
sandstone in that district. The first well, which is at the lime plant in the SE. $\frac{1}{4}$ sec. 28 , T. 2 N., R. 7 E., begins on top of the Minnekahta limestone and is 250 feet deep, reaching the middle of the upper sandstone of the Minnelusa. The main flow of 100 gallons a minute began at a depth of 215 feet and did not increase below that point. Another well in the northeast quarter of the next section south obtains a similar supply from the same source at a depth of 205 feet. The third well is in the SW. $\frac{1}{4}$ sec. 34, nearly a mile southeast of the second. It is 500 feet deep and flows about 60 gallons. It was necessary to go 500 feet at this place to reach the same stratum as in the other wells, for the beds pitch steeply to the southeast, as shown by an outlier of the Sundance formation at the road forks, less than half a mile southeast.

A few borings of moderate depth have been made east of Rapid City, but none sufficiently deep to reach the Dakota sandstone. Owing to the relatively steep dip of the rocks, the depth to this sandstone increases rapidly east of the hogback ridge. In the eastern part of Rapid City the depth is 500 feet, and along the eastern margin of R. $8 \mathrm{E}$. it is probably considerably more than 2,500 feet. Doubtless flowing wells could be obtained at depths of 500 to 1,500 feet along the valley of Rapid Creek west of the center of R. 8 E., and at a depth of 1,500 feet in the wide flats west of Box Elder Creek, 2 miles northeast of Rapid City. At Brennan the sandstone probably lies at a depth of about 1,300 feet, but whether it would yield a flow is somewhat doubtful, for the limit of the area in which flows may be expected is in the vicinity of the railroad at Brennan.

A boring made at Wasta, a few miles east of the border of the area shown on the map (P1. I, in pocket), is 2,287 feet deep. At 2,208 feet a 3 -foot bed of sandstone was penetrated and yields water that rises within 300 feet of the surface, here 2,315 feet above sea level. The supply is $\mathbf{4 0}$ gallons a minute, and is obtained with a 4-inch pump barrel at a depth of 900 feet. The sandstone evidently is included in either the Carlile or Graneros shale, probably the Graneros; and if so the Dakota sandstone is not far below.

HERMOSA REGION.

In the valleys of Spring and Battle creeks conditions are similar to those in the Rapid City region. Probably flowing wells can be obtained in all the bottom lands and lower slopes of the larger valleys. The area in which flows of water from the Dakota and Lakota sandstones may be obtained is somewhat uncertain, for the boundaries shown on the map (Pl. I, in pocket) are constructed from head lines that are only approximately located. It is probable that 
Hermosa station is near the edge of the area and that a flow might be obtained there from the Dakota or Lakota sandstones. The Dakota is probably not more than 700 feet below the surface. The Iakota lies 850 feet below, and from it the greatest head and largest flow are to be expected. On the east line of R. 8 E. the depth to the Dakota sandstone is between 1,600 and 1,700 feet on Battle Creek and also on Spring Creek. It gradually deepens to the east, probably to 2,600 feet on the east line of R. $9 \mathrm{E}$.

In the Red Valley west of Hermosa the Minnelusa sandstone is within reach for ordinary well boring and is likely to yield a flow in the lower and middle slopes. The depth is 150 feet to the top sandstone at the foot of the limestone slopes and 750 to 800 feet along the eastern edge of the red beds of the Spearfish formation. At Hermosa it is about 2,200 feet below the surface, and the top or lower sandstones are likely to afford a flow under considerable pressure. The Deadwood sandstone is about 1,000 feet below the top of the Minnelusa sandstone in this region.

\section{FAIRBURN REGION.}

The artesian conditions in the Fairburn region (see Pl. I, in pocket, and section 5, P1. X, p. 26) are similar to those all along the east slope of the Black Hills. No wells have been sunk, and the water resources are therefore untested, but there is every probability that water is obtamable. Flows may be expected along the valleys of Dry Creek and French Creek, from the foot of the hogback ridge eastward, with gradual increase in depth and diminution of head. At Fairburn the head of the first flow is probably sufficient to raise the water to about 3,300 feet above sea level (Fairburn station is 3,310 feet), or sufficiently high to afford $a$ ffow in the lower lands near by. Somewhat greater head may be expected from lower flows. The depth to the top of the Dakota sandstone is 900 to 1,000 feet at Fairburn. It increases steadily to the east, and in the northeast corner of T. 5 S., R. 8 E., it is 2,500 feet, east of which it increases but slightly, for the strata fie nearly horizontal.

At Fairburn the Minnelusa sandstone is about 2,500 feet bclow the surface and the Deadwood sandstone 800 to 900 feet deeper, but in the Red Valley the depth to the Minnelusa is only 140 to 1,200 feet, and to the Deadwood sandstone 1,000 to 2,000 feet. Both probably contain artesian watex under considerable pressure.

BUFFALO GAP AND SMTTHWTCK REGION.

Several deep borings have been made in and near the bown of Buffalo Gap, but nome of threm was sufficiently deep to be successful. One was on a hill just west of the town. Another, on the principal 
street, was 800 foet deep, entirely in black shale. It began in the lower part of the Carlile shale, above the Greenhorm limestone, and passed far down into the Graneros shale. Probably the Dakota sandstone would have been entered at a depth of about 1,100 feet and a flow obtained.

The most recent attempt to obtain water was by a deep well a mile west of town, which was drilled in 1910 , but it was located too high to have a flow. The depth was 884 feet. No record was obtainable as the well was sunk by jetting, but it is reported that the base of the shale was between 500 and 600 feet. The well was cased with $4 \frac{1}{2}$ to 2 inch pipes and the 2 -inch pipe was perforated from 654 to 784 feet. Water that could be pumped was obtained at 654 to 784 feet, and though at first it came to the top it settled back to 725 feet. However, after two years this afforded a small flow which has continued since.

All the conditions appear to be favorable for obtaining flows in all of the lower lands of the valleys of Lame Johnny, Dry, and Beaver creeks and Cheyenne River, north, south, and east of Buffalo Gap. (See map, PI. I, in pocket.) Owing to the relatively steep dips of the rocks near the hogback ridge the depths to the water-bearing sandstones increase rapidly to the east for some distance. At Buffalo Gap station the depth is about 1,300 feet, and in the next 2 or 3 miles it increases to 2,300 feet. The dips flatten in R. 8 E. (see section $6, \mathrm{Pl} . \mathrm{X}$, p. 26), and the strata rise slightly in a low dome in the next two ranges east. The Dakota sandstone lies, however, at a depth of 2,300 to 2,600 feet in this region. The area in which flows may be obtained undoubtedly extends up the valley of Cheyenne River past Oral to the mouth of Fall Creek and possibly also to the mouth of the gorge in which the river crosses the hogback ridge a few miles above Cheyenne Falls.

Artesian water will perhaps be found in the Minnelusa sandstone also, unless the rock becomes too fine grained, as at Edgemont and Minnekahta. It lies from 500 to 800 feet below the surface in the lower parts of Martins Valley. Probably the water in the large springs in the upper part of Buffalo Gap rises from this sandstone through the Opeche beds, and if so, there is much encouragement for believing that the sheet of water may be widespread. About 1,100 feet below the surface is the Deadwood sandstone, which undoubtedly carries a large water supply, as in deep wells at Edgemont.

\section{HOT SPRINGS AND MINNEKAHTA REGION.}

The town of Hot Springs extends nearly all the way across the Red Valley and is underlain by the Minnelusa sandstone at depths ranging from about 200 feet in the western part of the town to 800 feet or more in the eastern part of the "old town." It is likely that this 
sandstone contains water throughout the Red Valley and that additional supplies are obtainable in the Deadwood sandstone about 1,000 feet below. Probably the warm water of the noted springs above Hot Springs is from this source and thus rises 1,000 feet or more through crevices in overlying rocks. Otherwise it is difficult to ac-

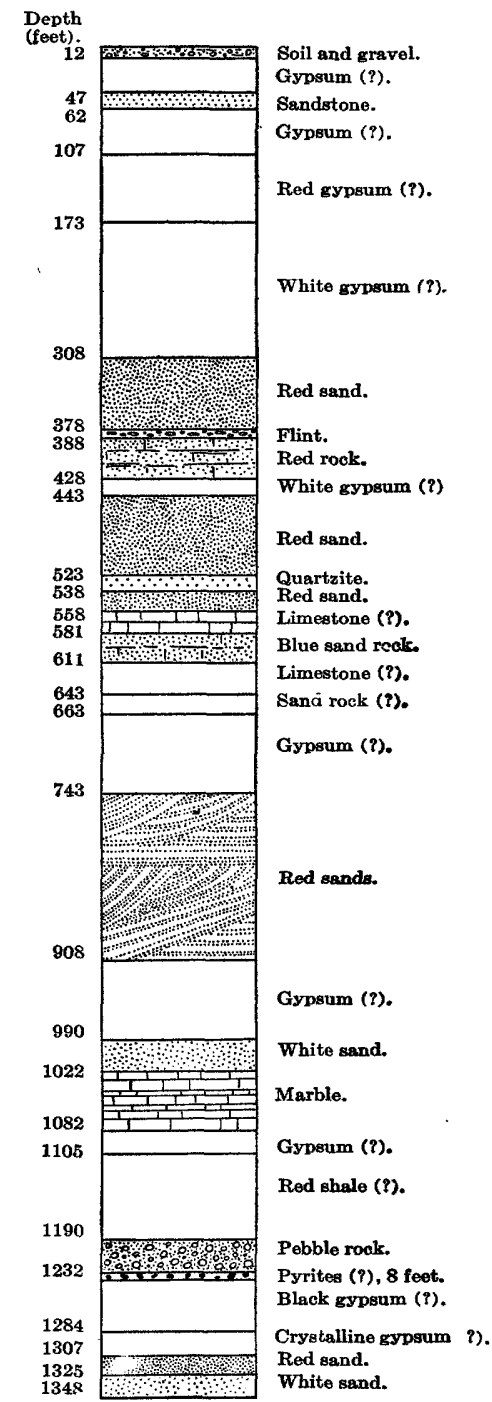

FigURe 9.--Section of deep boring at Minnekahta, S. Dak.

count for their temperature, which is about $45^{\circ}$ higher than the mean annual temperature of the locality. The water of the tepid springs at Cascade doubtless comes from the same horizon. At the Soldiers' Home, a short distance west of Hot Springs, a well, sunk several years ago to a depth of 223 feet, begins just above the top of the 
Minnekahta limestone and obtains a moderate water supply from the Minnelusa sandstone.

Several years ago the Chicago, Burlington \& Quincy Railroad Co. made a deep boring at Minnekahta station to obtain a water supply for locomotives. A depth of 1,348 feet is said to have been attained, but no satisfactory amount of water was found. The section shown in figure 9 is clearly unreliable and very unsatisfactory for the identification of the rocks penetrated. The reference to gypsum, except those near the top, are mistakes as to the identity of the material. No clue is given as to the position of the Minnekahta limestone, which lies about 500 feet below the surface. The red sands from 743 to 908 feet are doubtless part of the Minnelusa sandstone. At a depth of 1,348 feet the boring should be in or near the Deadwood sandstone, for the thickness of the beds from the upper part of the Spearfish red shale, in which the boring was started, to the top of the Deadwood sandstone is not much more than this in the surface exposures in the region to the.north. Possibly the red sand reported from 1,307 to 1,325 feet is from the top of the Deadwood sandstone, and if so the boring would have found the water-bearing strata of the deep Edgemont wells at no great depth below. As the Minnekahta station is at an altitude of 4,163 feet, and as the altitude of intake of the Deadwood sandstone near Pringle is at about 5,000 feet, it is probable that the water would flow throughout this portion of the Red Valley.

\section{EDGEMONT REGION.}

Edgemont.-Two deep artesian wells afford a large water supply for Edgemont. One, in the northern edge of the town, sunk by the Chicago, Burlington \& Quincy Railroad in 1905, reached a depth of 2,980 feet in 1907 , and the other, sunk by the city in 1912 a few rods south of the depot, is 2,983 feet deep. They both yield large flows of warm water $\left(122^{\circ}\right.$ and $126^{\circ} \mathrm{F}$.) under pressure of about 75 pounds to the square inch, probably derived from Deadwood sandstone. (See section 6, Pl. X, p. 26.) Several shallower wells penetrate the Dakota and underlying sandstones, but the head of the water in these beds is too low to afford a flow. The flow in the deep railroad well began at 2,920 feet and finally it was' 300 gallons a minute as boring progressed. At first the water contained much mineral matter, evidently derived from red sandstone in higher beds, for the boring was not cased between 1,850 and 2,111 feet, but a 5-inch casing inserted to the latter depth cut off this water and the main supply was. then found to be satisfactory for locomotives. (See analysis, p. 57.) The following is the record furnished by the company, with slight modifications based on examination of samples sent by the drillers and others: 


\section{Record of artesian well of Chicago, Burlington \& Quincy Railroad Co. at Edgemont, S. Dak.}

Clay and sand, with gravel at base

Feet. $0-33$

Shale, dark

Sandstone

Shale, with 3-inch bed of hard sandstone at 297 feet_-

"Limestones" separated by 2 feet and 9 feet of lightcolored shales (probably top of Dakota)

Shale, dark, compact

Sandstone, hard, with 6 feet of dark shale near top.Pyrites (?)

Shale, gray, with 2-foot hard layer

Sandstone, with dark shale near base

Shale, mostly light and soft

Sandstone ("limestone" in middle; 4 feet hard shale at 489 feet)

Shale, compact, light

Sandstone, hard, and sandy "limestone"

Shale, sandy

Sandstone, red

Shale, sandy, compact

Sandstone, with water

Shale, sandy, compact, with 24 feet of "limestone" at 740 feet.

Sandstone, light-colored (Unkpapa)

Sandy shale, compact (probably top of Sundance) --Shale, blue

Sandstone

Shale, red, sandy (probably red member of Sundance formation)

Sandstone, dark red, compact (probably red member of Sundance formation)

Shale, white, sandy $1,040-1,051$

Shale, blue

$1,051-1,060$

Sandstone, white; water rose to surface $1,060-1,080$

Shale, blue $1,080-1,098$

"Hardpan," black $1,098-1,157$

Sandstone, white, some water (low in Sundance) _.-.- 1, 174-1, 223

Shale, gray, limy (reported as black hardpan; probably at base of Sundance)

$1,223-1,230$

Red shale and sandstone (Spearfish)

Red sandstone (Minnekahta limestone, not reported) _ 1, 850-1,955

Limestone, light colored (probably fine Minnelusa sandstone)

$1,955-2,140$

Limest $d$ e, pale brown (probably fine Minnelusa sandstone)

$2,140-2,198$

Red sandstone ( 5 feet compact at top, then very soft for 24 feet)

$2,198-2,292$

Limestone

$2,292-2,303$

Sandstone, red and gray

$2,303-2,325$

Limestone, white

$2,325-2,352$

Sandstone, some lime (reported as limestone)

$2,352-2,440$

Limestone, white (Pahasapa)

$2,440-2,516$

Sandstone, red; dark brown below 
Sandstone, light brown; no lime $2,572-2,641$

Pyrites, dark 2, 641-2, 648

Red rock, soft above, light in middle, darker below 2, 648-2, 878

Sandstone, first flow between 2,920 and 2,948 feet_ $2,878-2,890$

Red sandstone, very hard 6-inch layer at 2,964 feet

$2,890-2,980$

The identity of some of the rocks given in this record is questionable, especially the so-called limestones, and the limits of the different beds are by no means accurate. Apparently the Dakota sandstone was reached at a depth of 297 feet, and presumably the base of the Lakota sandstone is the water-bearing sand from 669 to 672 feet. The Morrison, Unkpapa, and Sundance formations lie next below, with the sandstone in the lower part of the Sundance extending from 1,174 to 1,223 feet. The Spearfish began at 1,230 feet (according to another authority, at 1,255 feet, capped by 15 feet of coarse gray sand), and red beds continued with great uniformity to 1,955 feet, presenting a thickness of more than 700 feet. It is probable, however, that the Minnekahta limestone was penetrated at about 1,850 feet, and the Opeche red sandstone is included in the 700 feet of red beds. Possibly, also, some of the top sandstone of the Minnelusa is ineluded on account of its red color. The identity of the lower beds is difficult to establish. Many feet of the sandstones and limestones are Minnelusa. The base of the Pahasapa (and Englewood) limestones appears to be at the bottom of the thick body of limestane at a depth of 2,516 feet. The beds below this limestone to 2,920 feet are mostly sandstones and shales, largely red, but some of the sandstones are snuff-colored and very like the upper part of the Deadwood sandstone. No samples were obtained from the "sands" at 2,920 to 2,980 feet on account of the heavy flow of water.

An analysis of the water made for the railroad company 10 days after the well was cased is as follows:

\section{Analysis of water from Chicago, Burlington \& Quincy Railroad Co.'s artesian vell at Edgemont. S. Dak. ${ }^{a}$}

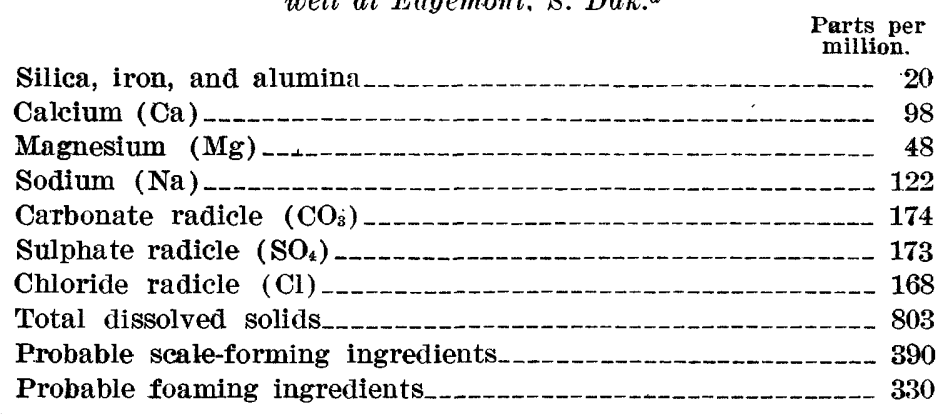

a This analysis was reported by the railroad company in grains per gallon and has been recalculated into ionic form and parts per million by the United States Geological Survey. The total contents in grains per gallon were given as 45.88 , of which sodium chloride was 16.19, sodium carbonate 1.69 , calcium sulphate 14.29 , calcium carbonate 3.85 , magnesium carbonate 9.86 , silica and insolublé matter 1.18 . 
In 1910 another deep well was sunk in Edgemont to supply water for city use. A flow of 575 gallons a minute was found at 2,970 feet. The pressure is 94 pounds to the square inch, and the temperature is $126^{\circ} \mathrm{F}$. The following record was supplied by the drillers:

Record of artesian well sunk in 1910 for city of'Edgemont, S. Dak.

\begin{tabular}{|c|c|c|}
\hline & $\begin{array}{l}\text { Thick- } \\
\text { ness. }\end{array}$ & Depth. \\
\hline & Feet. & Feet. \\
\hline $\begin{array}{l}\text { Clay, sand, and gravel.............. } \\
\text { Shale, mostly dark............... }\end{array}$ & $\begin{array}{r}60 \\
270\end{array}$ & $\begin{array}{r}60 \\
320\end{array}$ \\
\hline Sand; water rose to 20 feet below the surfa & 7 & 337 \\
\hline $\begin{array}{l}\text { Shale, gray to red, sandy near base. } \\
\text { Sand. } \ldots \ldots \ldots\end{array}$ & $\begin{array}{r}86 \\
6\end{array}$ & $\begin{array}{l}423 \\
429\end{array}$ \\
\hline Shale, biue...................... & 6 & 435 \\
\hline 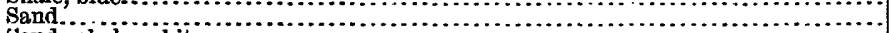 & 3 & 438 \\
\hline 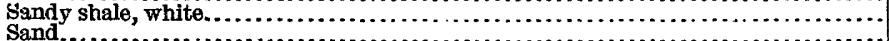 & $\stackrel{8}{9}$ & 446 \\
\hline Shale & $\mathbf{5}$ & $\begin{array}{l}400 \\
460\end{array}$ \\
\hline 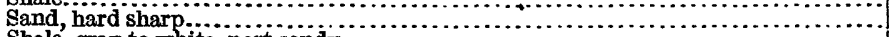 & 15 & 475 \\
\hline "Shale, gray to white, part sandy.... & $\overline{55}$ & 530 \\
\hline 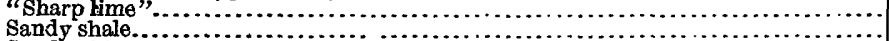 & 20 & 550 \\
\hline Sand, white.......... & 17 & 590 \\
\hline 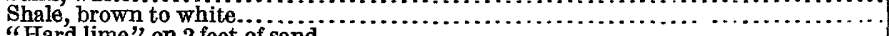 & 52 & 642 \\
\hline "Hard lime" on 2 feet of sand................... & $\begin{array}{r}36 \\
6\end{array}$ & 678 \\
\hline Shale, lower half soit and white....... & 71 & 755 \\
\hline "Lime" and shale................... & 10 & 765 \\
\hline 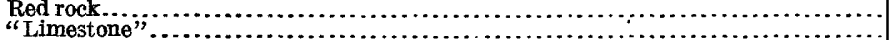 & $\begin{array}{l}8 \\
6\end{array}$ & $\begin{array}{l}773 \\
779\end{array}$ \\
\hline Sand, white...... & 18 & 797 \\
\hline 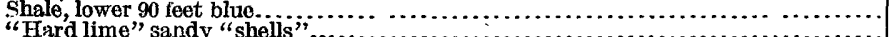 & $\begin{array}{r}161 \\
9\end{array}$ & 958 \\
\hline Shale, white and pink & 21 & 988 \\
\hline Red rock & & 994 \\
\hline Shale, part hard and white............ & 31 & 1,025 \\
\hline $\begin{array}{l}\text { Red rock, hard ..... blue below......... } \\
\text { Shale, white at top, }\end{array}$ & $\begin{array}{l}17 \\
54\end{array}$ & $\begin{array}{l}1.042 \\
1,096\end{array}$ \\
\hline Sand with water....................... & $\begin{array}{r}4 \\
78\end{array}$ & 1,100 \\
\hline Sand with 5 -gallon il & $\begin{array}{l}78 \\
67\end{array}$ & $\begin{array}{l}1,178 \\
1,245\end{array}$ \\
\hline Shale, hard.. & & 1,254 \\
\hline Red rocks, bard to soft. & 372 & 1,626 \\
\hline Lime, white, hard........ & 16 & $\begin{array}{l}1,654 \\
1,670\end{array}$ \\
\hline Red rocks, mostly soft, flow at 1,845 feet. & 185 & 1,855 \\
\hline 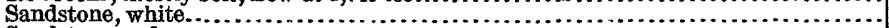 & 45 & 1,900 \\
\hline (n............... & 30 & 1,930 \\
\hline Iinestone, mostly white $\ldots \ldots \ldots \ldots$ & 152 & 2,082 \\
\hline$\theta$, red, gray, and white, very & 62 & 2,144 \\
\hline Red rock; caves easily................ & 111 & 2,255 \\
\hline $\begin{array}{l}\text { Sand, gray... } \\
\text { Shale, blue.. }\end{array}$ & $\begin{array}{r}21 \\
9\end{array}$ & $\begin{array}{l}2,276 \\
2,285\end{array}$ \\
\hline "Iime".. & 15 & 2,300 \\
\hline Red rock.. & 25 & 2,325 \\
\hline Sand, gray, soft be & 24 & 2,349 \\
\hline Sand, white, soft. ä.... & $\begin{array}{r}31 \\
145\end{array}$ & $\begin{array}{l}2,380 \\
2,525\end{array}$ \\
\hline ly "and blue shale. $\ldots \ldots \ldots \ldots \ldots \ldots$ & 90 & 2,615 \\
\hline 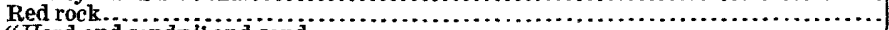 & 20 & 2,635 \\
\hline 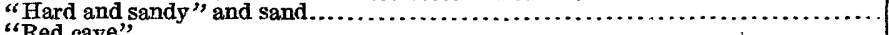 & 25 & 2,660 \\
\hline "Red cave".. & 12 & 2,697 \\
\hline Red rock. & 28 & 2,725 \\
\hline Limestone layer, white; bas hard red streaks. & 30 & 2,755 \\
\hline Red rock... & $\begin{array}{r}156 \\
39\end{array}$ & 2,911 \\
\hline 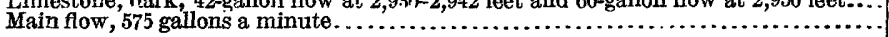 & 33 & 2,983 \\
\hline
\end{tabular}

This record corroborates the previous one in most respects, certainly as to the great flow of warm water at the bottom. Owing to the slight northward dip of the strata the beds are slightly deeper in the new well than in the old one. 
Apparently the Dakota sandstone was entered at 330 feet and probably the white sand at 779 to 797 feet is basal Lakota. The "red rocks," at 988 to 1,042 feet, suggest the red member in the middle of the Sundance formation, and the water-bearing sand 200 feet below is the lower sandstone of that formation. The red beds of the Spearfish formation begin at 1,254 feet, or 24 feet deeper than in the railroad well. The sand and lime reported at 1,626 to 1,670 feet are probably gypsum; and the "white sandstone," at 1,855 to 1,900 feet, may be gypsum or may be Minnekahta limestone, which is $\mathbf{4 5}$ feet thick at its outcrops $\mathbf{1 5}$ miles to the north. The overlying red beds are 601 feet thick, which is the estimated amount of the Spearfish formation in its outcrops to the north. The red beds at 1,900 feet are probably Opeche, but only 30 feet are reported. The sandstones below are the Minnelusa, which doubtless extends to 2,380 feet. According to the record the Pahasapa limestones are less characteristic than might be expected, and their lower limit is not indicated. Undoubtedly the lower sandstones are Deadwood and yield the flow. A small showing of oil was reported at 2,200 feet.

The well is cased with 34 feet of 16-inch pipe, 1,275 feet of 10 -inch pipe, 2,290 feet of 8 -inch pipe, and 2,912 feet of 6 -inch pipe.

It is interesting to compare the Edgemont well sections, or at least the portions of them from 850 to 2,300 feet, with the record of a boring recently made for oil on Old Woman Creek 25 miles southwest of Edgemont.

Record of boring for oil on old Woman Creek anticline, in the NW. $\frac{1}{4}$ sec. 9 , T. 36 N., R. 62 W., in Wyoming, 25 miles southwest of Edgemont, S. Dak.

\begin{tabular}{|c|c|c|c|}
\hline Formation. & Material. & $\begin{array}{l}\text { Thick- } \\
\text { ness. }\end{array}$ & Depth. \\
\hline 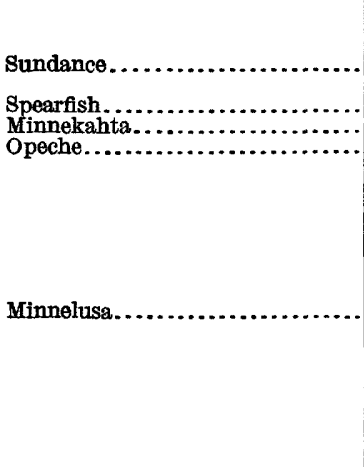 & 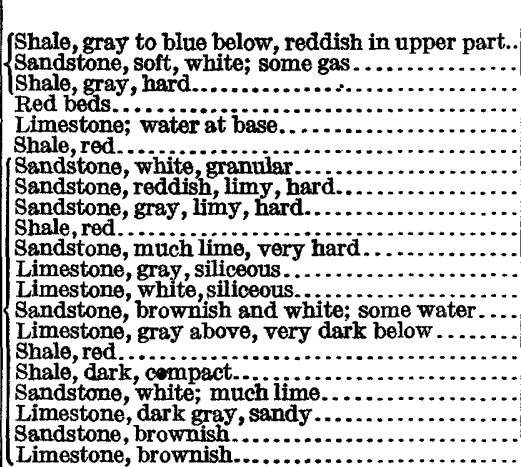 & $\begin{array}{r}\text { Feet. } \\
255 \\
80 \\
20 \\
415 \\
70 \\
80 \\
100 \\
18 \\
12 \\
10 \\
100 \\
30 \\
140 \\
20 \\
91 \\
9 \\
30 \\
20 \\
18 \\
26 \\
12\end{array}$ & $\begin{array}{r}\text { Feet. } \\
255 \\
335 \\
355 \\
770 \\
840 \\
\mathbf{9 2 0} \\
1,020 \\
1,038 \\
1,050 \\
1,060 \\
1,160 \\
1,190 \\
1,230 \\
1,250 \\
1,341 \\
1,350 \\
1,380 \\
1,400 \\
1,418 \\
1,444 \\
1,456\end{array}$ \\
\hline
\end{tabular}

In Edgemont and its vicinity a number of wells were sunk several years ago for water from the Dakota sandstone. Nearly all obtained supplies for pumping, but, owing to the low level of the outcrops 
of the Dakota sandstone in the vieinity, the water did not have sufficient head to flow. The water did not prove satisfactory for use in locomotives, and all the wells except the one 1,125 feet deep at the railroad roundhouse have been abandoned.

Sections of two wells are shown in figures 10 and 11. One of the wells at the roundhouse (fig. 10) had a depth of 1,125 feet but is now filled to the depth of 700 feet. Water of bad quality was found in

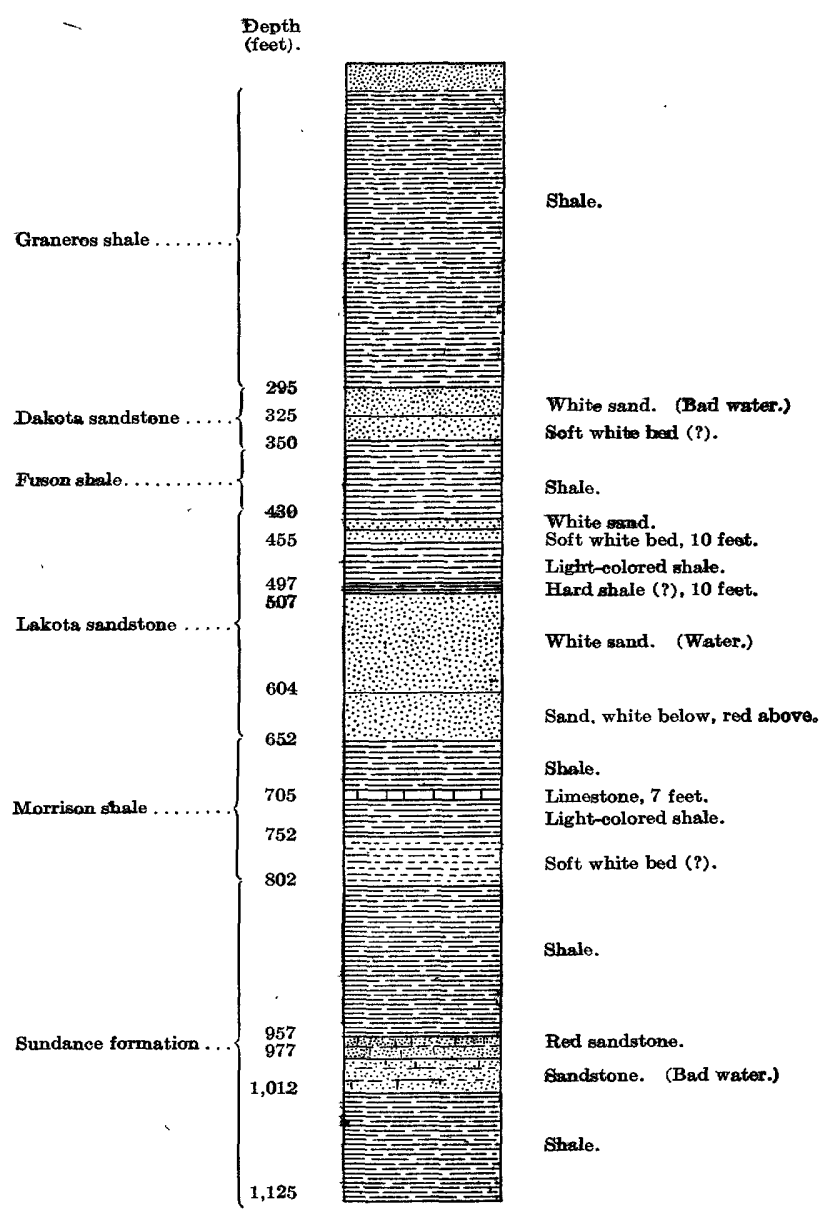

FIgUR日 10.-Section of nonflowing well at Edgemont, S. Dak.

the white sand at 295 feet and in the sandstone at 977 feet. Fairly good water, ${ }^{1}$ rising within 60 feet of the surface, is obtained from the sandstone which begins at a depth of 509 feet. It contains 4,080 parts per million of solid matter (239 grains per gallon), of which 159 parts is lime. The record appears to be fairly reliable; it indicates Dakota sandstone from 295 to 350 feet, Fuson shale from

${ }^{1}$ Darton, N. H., Geology and underground waters of South Dakota : U. S. Geol. Survey Water-Supply Paper 227, p. 95, 1909. 
350 to 430 feet, Lakota sandstone from 430 to about 652 feet, Morrison shale from 652 to 802 feet, Sundance shales and sandstones with the characteristic red series from 957 to 977 feet, and the bed of buff sandstone 977 to 1,012 feet, with the basal dark shales thence to 1,125 feet, which is probably not more than 40 feet above the top of the red beds of the Spearfish formation.

The well at the north end of the railroad $Y$ across the river from Edgemont (fig. 11) has a depth of 960 reet, and probably ends in shale of the Sundance formation, but the record appears not to be reliable in its details. Some water was found in the white sand at

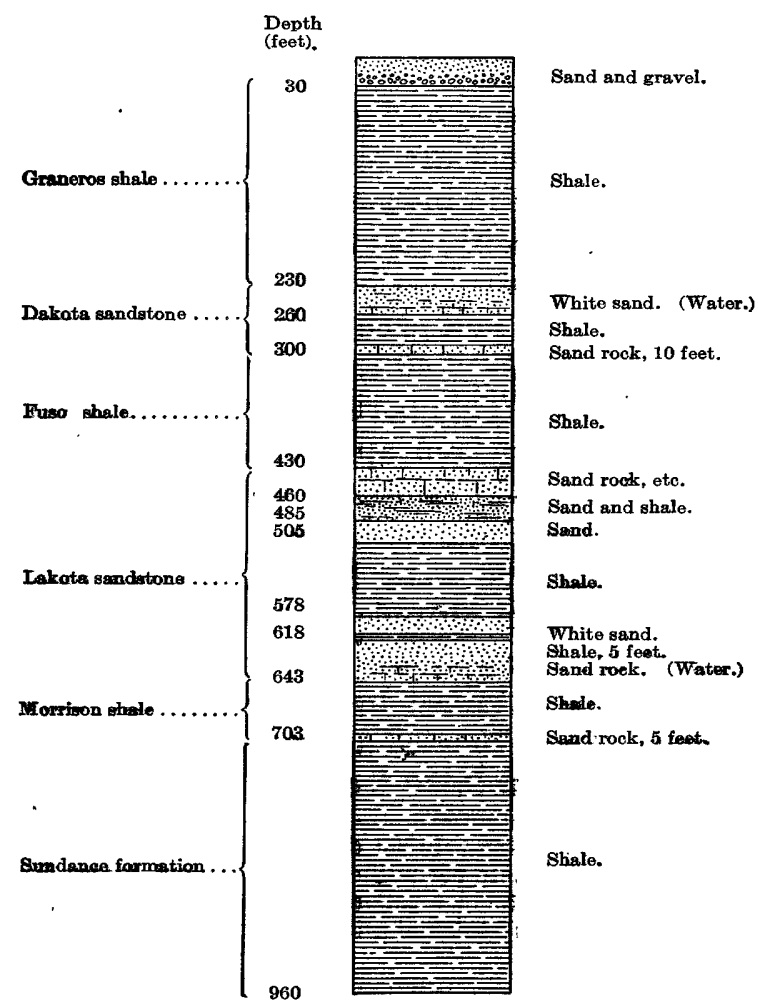

FIGURE 11.-Section of boring at railroad $Y$ three-fourths of a mile north of Edgemont, s. Dak.

230 feet and in sandstones at 290 and 430 feet. At 578 feet a sandstone begins which yields a good supply of water that rises within 30 feet of the surface. A thin sand rock at 703 feet also yields water, but its volume is small.

Argentine.-The Chicago, Burlington \& Quincy Railroad Co. has a flowing well on the south bank of Pass Creek just west of Argentine, a siding 13 miles northwest of Edgemont. It is 550 feet deep and yields considerable water, but its quality is not satisfactory for locomotives, as the following analysis shows: 
Analysis of artesian water from Argentine, ¿่. Dak. ${ }^{1}$

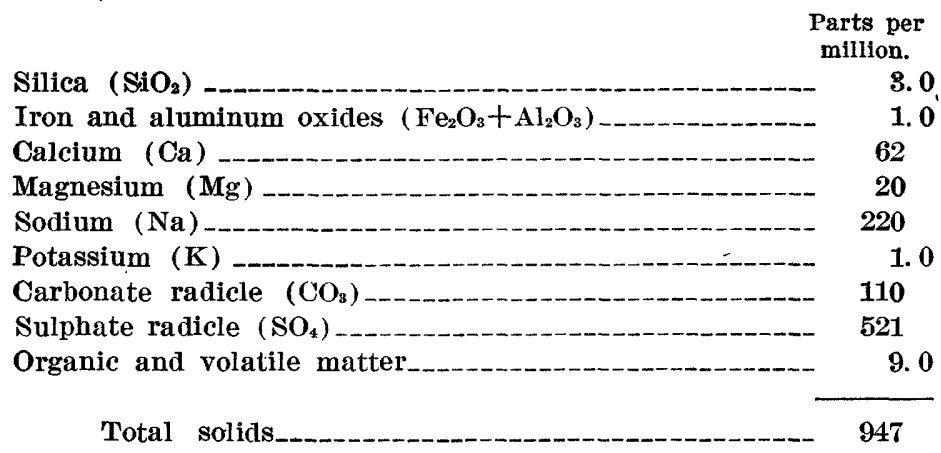

No record of the Argentine boring was obtained: It begins in the Graneros shale and undoubtedly obtains the flow from the Lakota sandstone, which crops out in the mountains not far east.

Ardmore.-At Ardmore, 23 miles south of Edgemont, the Chicago, Burlington \& Quincy Railroad Co. bored to a depth of 1,500 feet without obtaining water. The hole is entirely in shale, except at the bottom, where it penetrated about 40 feet of white sand, containing thin partings of black shale. This boring begins just about at the top of the Niobrara formation and apparently penetrates very nearly to the Dakota sandstone, the sandstone bed reported probably being in the lower part of the Graneros shale. As Ardmore is at an altitude of 3,557 feet, and the water-bearing Dakota sandstone crops out about Edgemont at an altitude of 3,400 feet, there is no possibility of a flow at the former place, but probably a supply of water for pumping could be obtained by deepening the boring into the Dakota sandstone. The estimated altitude to which the water would rise in such a well is about 3,450 feet.

1 The analysis was reported by the railroad company in grains per gallon, and has been recalculated into ionic form in parts per million by the United States Geological Survey. The total solids are about 55 grains per gallon, regarded as about 40 grains sodium and potassium sulphates and 12 grains calcium and magnesium sulphates and carbonates. 


\section{INDEX.}

Page.

Arontine, artes at----.

Artesian water, areas of flow of depths to head of -

Artesian wells, descriptions and records of 35-62

Bear Butte, structure of

Bear Butte region, artesian wells in $43-49$

Beaver Creek, artesian conditions on

Belle Fourche project, wells drilled

Belle Fourche region, area of flow in 38-39

artesian wells in

Black Hills, map showing artesian water conditions in the vicinity of _...-- In pocket.

Borings, descriptions and records of _ 35-62

Boulder Park, artesian conditions in

Brule clay, nature of

Buffalo Gap, borings near

Carlile shale, nature and occurrence of

Cascade Springs, S. Dak., spring at, plate showing.......

Caverns, occurrence of

Centennial Prairie, artesian conditions in

structure of

Chadron formation, nature of Chambers ranch, borings on

Cheyenne River, artesian conditions on

Chicago, Burlington \& Quincy R. R. Co., boring of, at Ardmore

well of, at Argentine

at Edgemont, analysis of water from record of

Coal, occurrence of .

Converse, W. A., analysis by

Dakota sandstone, artesian water in - 29-32 nature and distribution of plate showing.

Deadwood formation, artesian water from -

nature and distribution of ..... upper sandstone of, plates show-

$$
\text { ing. }
$$

Depths to artesian

Dry Creek, artesian conditions on

Edgemont, record of city well at_-- 58

Edgemont region, artesian wells in

Elkhorn Peak, structure of _._._.- 24

Empire, artesian conditions near... 43

Englewood limestone, nature and distribution of _. 11 possibility of water from

Fairburn region, artesian conditions in

Fort Meade, well at_._._. 47

Fossils, occurrence of $14,15,16,17,19,20,21,22,23$

plates showing

Furth Hotel, Sturgis, boring at__-_ 47

Fuson shale, nature and distribution of _._. 18-19

Geologic section, generalized__._-_ 9

Geology of the region

Grade hydraulic, how produced_._-_ 29-31

Graneros shale, nature and distribution of _._._...... 19-20

Greenhorn limestone, nature and distribution of _..._._. 20

on Graneros shale, plate showing

Ground water. See Underground water.

Gypsum, occurrence of

Hay Creek valley, artesian wells in $\quad 39$

Haystack Butte, structure of._..... 24

Head of underground water, declipity of

Hermosa region, artesian wells in

Hogback ridge, south of Buffalo Gap, plate showing - 20

structure of

Horse Creek, artesian conditions near.-

Hot Springs region, artesian conditions in

Inoceramus labiatus, occurrence of $-20,32$ plate showing - 32

Lakota sandstone, artesian water in 29_32 nature and distribution of _... $\quad 17$ plate showing

Lame Johnny Creek, artesian conditions 'on

Limestone Ridge, stmucture of Lucina occidentalis, occurrence of-- 22 
